\title{
Buku Ajar Mata Kuliah \\ Asuhan Kebidanan NIfas dan Menyusui
}

Oleh

Nurul Azizah; Rafhani Rosyidah

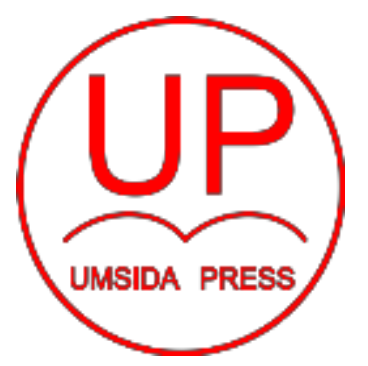

Diterbitkan oleh

UMSIDA PRESS

Tahun 2019 
Buku Ajar

Asuhan Kebidanan NIfas dan Menyusui

Penulis :

Nurul Azizah; Rafhani Rosyidah.

ISBN :

978-602-5914-78-2

\section{Editor :}

Septi Budi Sartika, M.Pd

M. Tanzil Multazam, S.H., M.Kn.

\section{Copy Editor :}

Fika Megawati, S.Pd., M.Pd.

Design Sampul dan Tata Letak :

Mochamad Nashrullah, S.Pd

\section{Penerbit :}

UMSIDA Press

\section{Redaksi :}

Universitas Muhammadiyah Sidoarjo

J1. Mojopahit No 666B

Sidoarjo, Jawa Timur

Cetakan pertama, Agustus 2019

C Hak cipta dilindungi undang-undang

Dilarang memperbanyak karya tulis ini dengan suatu apapun tanpa ijin tertulis dari penerbit. 
Assalammu'alaikum Wr.Wb

Asuhan kebidanan nifas dan menyusui merupakan salah satu bidang ilmu yang bertujuan untuk membantu ibu nifas dalam proses penyembuhan pasca bersalin. Tujuan tersebut tidak akan tercpai apabila tidak didukung dengan kajian ilmu kebidanan yang baik. Buku ini ditujukan untuk mahasiswa kebidanan sebagai bentuk pembelajaran mengenai pengkajian, pemeriksaan serta penanganan permasalahan kesehatan yang terjadi pada masa nifas. Dan dapat mendukung para mahasiswa bidan agar dapat mempraktikkan tindakan kebidanan sesuai dengan kondisi yang dialami ibu pada masa nifas.

Buku ajar dalam mata kuliah Asken III (Nifas) merupakan keinginan para dosen guna membantu mahasiswa dalam proses pembelajaran. Buku ini terdiri dari 9 bab antara lain membahas konsep dasar nifas, perubhan fisiologi pada masa nifas, adaptasi psokologi pada masa nifas, respon orang tua terhadap bayi baru lahir, kebutuahn dasar masa nifas, proses laktasi dan menyusui. Buku ini diperuntukkan bagi mahasiswa kebidanan yang disusun berdasarkan silabus mata kuliah . Penyusunan buku ajar askeb III (Nifas) ini tidak lepas dari bantuan dan bimbingan serta motivasi dari semua pihak. Kami berharap dapat membawa manfaat bagi seluruh mahasiswa. Kami mengharapkan saran dan masukan dari para pembaca, sehingga dapat memperbaiki

dikemudian hari.

Wassalamualaikum Wr.Wb

Sidoarjo, Oktober 2019

Penulis 


\section{DAFTAR ISI}

Halaman

COVER

i

ii

DAFTAR

PRAKATA

iii

BAB 1 KONSEP DASAR NIFAS
1.1
DEFINISI
MASA
NIFAS

1

1.2

TUJUAN

ASUHAN

MASA

NIFAS

1

1.3 PERAN DAN TANGGUNG JAWAB BIDAN DALAM MASA NIFAS 5

1.4 TAHAPAN MASA NIFAS 7

1.5 KEBIJAKAN PROGRAM MASA NIFAS 8

\section{BAB 2 PERUBAHAN FISIOLOGI MASA NIFAS}

2.1 PERUBAHAN SISTEM REPRODUKSI

10

2.2 PERUBAHAN SISTEM PENCERNAAN

18

2.3 PERUBAHAN SISTEM PERKEMIHAN 20

2.4 PERUBAHAN SISTEM MUSKULOSKELETAL/DIASTASIS REKTI ABDOMINALIS

2.5 PERUBAHAN SISTEM ENDOKRIN 
2.6 PERUBAHAN TANDA-TANDA VITAL 28

2.7 PERUBAHAN SISTEM KARDIOVASKULAR 29

2.8 PERUBAHAN SISTEM HEMATOLOGI 30

BAB 3 PROSES ADAPTASI PSIKOLOGI PADA MASA NIFAS

3.1 PROSES ADAPTASI PSIKOLOGI MASA NIFAS 32

$\begin{array}{lll}3.2 & \text { POST PARTUM BLUES } & 37\end{array}$

3.3 EDINBURG POSTNATAL DEPRESSION SCALE (EPDS) 40

3.4 KESEDIHAN DAN DUKA CITA/DEPRESI 41

BAB 4 RESPON ORANG TUA TERHADAP BAYI BARU LAHIR

4.1 BOUNDING ATTACHMENT 45

4.2 RESPON AYAH DAN KELUARGA 51

4.3 SIBLING RIVALRY 57

BAB 5 KEBUTUHAN DASAR MASA NIFAS

5.1 NUTRISI DAN CAIRAN 63

5.2 AMBULASI DINI (EARLY AMBULATION) 67

5.3 ELIMINASI (BAB \& BAK) 68

5.4 PERSONAL HYGIENE DAN PERINIUM 70

$\begin{array}{ll}5.5 \text { ISTIRAHAT } & 73\end{array}$

$\begin{array}{lll}5.6 & \text { SEKSUAL } & 74\end{array}$

5.7 KELUARGA BERENCANA $\quad 75$

5.8 LATUHAN/SENAM NIFAS 76

BAB 6 MANAJEMEN KEBIDANAN PADA IBU NIFAS

6.1 PENGKAJIAN 86

6.2 MERUMUSKAN DIAGNOSA/MASALAH POTENSIAL 99

6.3 MERENCANAKAN ASUHAN KEBIDANAN 100

6.4 PELAKSANAAN ASUHAN KEBIDANAN 111

$\begin{array}{ll}6.5 \text { EVALUASI } & 114\end{array}$

BAB 7 PROGRAM TINDAK LANJUT ASUHAN NIFAS DI RUMAH

7.1 JADWAL KUNJUNGAN RUMAH 116

7.2 ASUHAN LANJUTAN MASA NIFAS DIRUMAH 116 
BAB 8 DETEKSI DINI KOMPLIKASI PADA MASA NIFAS

8.1 PERADARAHAN PERVAGINA

8.2 INFEKSI MASA NIFAS

8.3 SAKIT KEPALA, NYERI EPIGASTRIUM DAN PENGLIHATAN KABUR

8.4 PEMBENGKAKAN DI WAJAH ATAU EKSTERMITAS

8.5 DEMAM, MUNTAH, RASA SAKIT WAKTU BERKEMIH

8.6 PAYUDARA BERUBAH MENJADI MERAH, PANAS, DAN SAKIT

8.7 KEHILANGAN NAFSU MAKAN UNTUK JANGKA WAKTU YANG LAMA

8.8 RASA SAKIT, MERAH, DAN PEMBENGKAKAN KAKI

8.9 MERASA SEDIH ATAU TIDAK MAMPU UNTUK MERAWAT BAYI DAN DIRI SENDIRI

\section{BAB 9 PROSES LAKTASI DAN MENYUSUI}

9.1 DEVINISI ASI DAN LAKTASI

9.2 ANATOMI FISIOLOGI PAYUDARA

9.3 FISIOLOGI LAKTASI

9.4 TAHAPAN LAKTOGENESIS

9.5 KOMPOSISI NUTRISI ASI

9.6 FAKTOR-FAKTOR YANG MEMPENGARUHI PROSES LAKTOGENESIS

9.7 PERBEDAAN ASI

9.8 KEUNTUNGAN MENYUSUI BAGI IBU DAN BAYI 166

9.9 PENILAIAN PRODUKSI ASI

9.10 UPAYA MEMPERBANYAKASI

9.11 ASI EKSKLUSIF

9.12 PEMBERIAN ASI BAGI IBU BEKERJA DI LUAR RUMAH 176

9.13 PERAWATAN PAYUDARA 
DAFTAR PUSTAKA

BIODATA PENULIS

RINGKASAN 


\section{BAB I : Konsep Dasar Nifas}

\subsection{Definisi Masa Nifas}

Masa nifas merupakan periode yang akan dilalui oleh ibu setelah masa persalanian, yang dimulai dari setelah kelahiran bayi dan plasenta, yakni setelah berakhirnya kala IV dalam persalinan dan berakhir sampai dengan 6 minggu (42 hari) yang ditandai dengan berhentinya perdarahan. Masa nifas berasal dari bahasa latin dari kata puer yang artinya bayi, dan paros artinya melahirkan yang berarti masa pulihnya kembali, mulai dari persalinan sampai organ-organ reproduksi kembali seperti sebelum kehamilan.

Pada masa nifas juga dapat timbul berbagai masalah baik yang berupa komplikasi fisik maupun komplikasi psikologis, oleh karena itu sangatlah penting perhatian khusus dari tenaga kesehatan terutama bidan. Oleh karena itu masa ini merupakan masa yang cukup penting bagi tenaga kesehatan untuk selalu melakukan pemantauan karena pelaksanaan yang kurang maksimal dapat menyebabkan ibu mengalami berbagai masalah, bahkan dapat berlanjut pada komplikasi masa nifas, seperti sepsis puerpuralis, perdarahan dll.

Pada masa ini dapat disebut masa kritis bagi ibu setelah melahirkan, skitar 50\% kematian ibu dapat terjadi dalam 24 jam pertama postpartum akibat perdarahan serta penyakit komplikasi yang terjadi pada saat kehamilan, Jika di tinjau dari penyebab adanya masalah yang dialami oleh ibu dapat berimbas juga terhadap kesejahteraan bayi yang dilahirkan, karena bayi tidak akan mendapatkan perawatan maksimal dari ibunya, dengan demikian, angka morbiditas dan mortalitas bayipun akan meningkat.

\subsection{Tujuan Asuhan Masa Nifas}

Berdasarkan standart pelayanan kebidanan untuk ibu nifas meliputi perawatan bayi baru lahir ( standard 13), penangnan 2 jam pertama setelah persalinan (standard 14), serta pelayanan bagi ibu dan bayi 
pada masa nifas (standard 15). Apabila merujuk pada kompetensi 5 (standar kompetensi bidan), maka prinsip asuhan kebidanan bagi ibu pada masa nifas dan menyusui harus yang bermutu tinggi serta tanggap terhadap budaya setempat. Jika dijabarkan lebih luas sasaran asuhan kebidanan masa nifas meliputi hal-hal sebagai berikut:

\section{Asuhan yang diberikan kepada ibu nifas bertujuan untuk :}

1) Meningkatkan kesejahteraan fisik dan psikologi ibu dan bayi Dengan diberikannya asuhan, ibu akan mendapatkan fasilitas dan dukungan dalam upaya untuk menyesuaikan peran barunya sebagai ibu (pada kasus ibu dengan kelahiran anak pertama) dan pendampingan keluarga dalam membuat pola baru saat kelahiran anak kedua. Jika ibu dapat melewati masa ini dengan baik maka kesejahteraan fisik dan psikologis bayipun akan meningkat

Menjaga kesehatan ibu dan bayinya baik fisik maupun psikologis harus diberikan oleh tenaga kesehatan. Misalnya ibu dianjurkan untuk menjaga kebersihan seluruh tubuh, sedangkan bidan mengajarkan pada ibu bagaimana membersihkan daerah kelamin dengan sabun dan air, dengan memastikan bahwa ia mengerti untuk membersihkan daerah vulva terlebih dahulu, dari depan ke belakang dan setelah itu membersihkan daerah sekitar anus. Sarankan ibu untuk mencuci tangan dengan sabun dan air sebelum dan sesudah membersihkan daerah kelaminnya. Jika ibu mempunyai luka episiotomy atau laserasi pada perimium sarankan ibu untuk menghindari atau tidak menyentuh daerah luka.

2) Pencegahan, diagnosa dini, dan pengobtan komplikasi pada ibu nifas

Dengan diberikannya asuhan pada ibu nifas, kemungkinan munculnya permasalahan dan komplikasi akan lebih cepat terdeteksi sehingga penangananya dapat lebih maksimal. 
Contohnya : Tujuan perawatan masa nifas adalah untuk menghindarkan/mendeteksi adanya kemungkinan adanya pendarahan postpartum dan infeksi. Oleh karea itu, penolong persalinan sebaikya tetap waspada sekurang-kurangnya 1 jam postpartum untuk mengatasi kemungkinan terjadinya komplikasi persalinan. Umumnya wanita sangat lemah setelah melahirkan, terlebih lagi jika persalinan berlangsung lama.

3) Merujuk ibu ke asuhan tenaga ahli jika diperlukan Meskipun dan keluarga mengetahui ada permasalahan kesehatan pada ibu nifas yang memerlukan rujukan, namun tidak semua keputusan dapat diambil secara tepat. Misalnya mereka lebih memilih untuk tidak datang pada fasilitas pelayanan kesehatan karena pertimbangan tertentu, jika bidan senantiasa mendampingi pasien dan keluarga maka keputusan tepat dapat diambil sesuai dengan kondisi pasien sehingga kejadian mortalitas dapat dicegah.

Memberikan skrining secara komprehensif : Melaksanakan skrining secara komprehensif dengan mendeteksi masalah, mengobati, dan merujuk apabila terjadi komplikasi pada ibu maupun bayinya. Seorang bidan bertugas untuk melakukan pengawasan kala IV yang meliputi pemeriksaan plasenta, pengawasan Tinggi Fundus Uteri, pengawasan perdarahan, pengawasan konsistensi Rahim, dan pengawasan keaadan umum ibu. Bila ditemukan permasahalan, maka harus segera melakukan tindakan sesuai dengan standar pelayanan pada penatalaksanaan masa nifas.

4) Mendukung dan meningkatkan keyakinan ibu, serta memungkinkan ibu untuk mampu melaksanakan perannya dalam situasi keluarga dan budaya khusus

Pada saat memberikan asuhan nifas, keterampilan seorang bidan sangat di tuntut untuk memberikan pendidikan kesehatan 
terhadap ibu dan keluarga. Keterampilan yang harus di kuasai oleh bidan, antara lain berupa materi pendidikan, teknik penyampaian, dan media yang digunakan, serta pendekatan psikologis yang efektif sesuai dengan budaya setempat. Hal tersebut sangat penting untuk diperhatikan karena banyak pihak yang beranggapan bahwa jika bayi telah lahir dengan selamat dan kodisi ibu dan bayi tidak ada cacat secara fisik maka sebuah pendampingan dianggap tidak perlu dilakukan. Padahal bagi para ibu (terutama ibu baru), saat menjalani peran barunya sangatlah berat sehingga membutuhkan sebuah pendampingan untuk kesehatan ibu dan bayi baik secara fisik maupun psikis.

5) Imunisasi ibu terhadap tetanus.

Dengan pemberian asuhan yang maksimal pada ibu nifas kejadian tetanus dapat dihindari, meskipun saat ini angka kejadian tetanus telah mengalami penurunan. Akan tetapi tetap memerlukan suatu tindakan untuk menghindari kejadian tetanus datang kembali.

6) Mendorong pelaksanaan metode yang sehat tentang pemberian makan anak, seta peningkatan pengembangan hubungan yang baik antara ibu dan anak.

Saat bidan memberikan asuhan masa nifas, materi dan pemantauan yang diberikan tidak hanya pada sebatas lingkup permasalahan ibu, tetapi bersifat menyeluruh terhadap ibu dan anak. Kesempatan untuk berkonsultasi tentang kesehatan termasuk kesehatan anak dan keluarga akan sangat terbuka. Bidan akan mengkaji pengetahuan ibu dan keluarga mengenai upaya mereka dalam rangka peningkatan kesehatan keluarga. Upaya peningkatan pola hubungan psikologis yang baik antara ibu dan anak.

Memberikan pendidikan kesehatan diri : Memberikan pelayanan kesehatan tentang perawatan diri, nutrisi, KB, menyusui, Asuhan kebidanan III (Nifas) 4 
pemberian imunisasi kepada bayinya, dan perawatan bayi sehat. Ibu postpartum harus diberikan pendidikan mengenai pentingnya gizi antara lain kebutuhan gizi ibu menyusui.

\subsection{Peran Dan Tanggung Jawab Bidan Dalam Masa Nifas}

1) Teman terdekat, sekaligus pendamping ibu nifas dalam menghadapi situasi kritis saat masa nifas.

Pada awal masa nifas, ibu mengalami masa-masa sulit. Saat itulah ibu sangat membutuhkan teman dekat yang bisa diandalkan oleh ibu untuk mengatasi kesulitan yang dialami. Bagaimana pola hubungan yang terbentuk antara ibu dan bidan akan sangat ditentukan oleh keterampilan bidan dalam memberikan asuhan, serta sebagai teman dekat pendamping ibu. Jika pada tahap ini hubungan yang terburuk sudah baik maka tujuan dari asuhan akan lebih mudah tercapai.

2) Pendidik dalam usaha pemberian pendidikan kesehatan terhadap ibu dan keluarga

Masa nifas merupakan masa yang paling efektif bagi bidan dalam menjalankan perannya sebagai pendidik. Dalam hal ini, tidak hanya ibu yang mendapatkan materi kesehatan, tetapi juga keluarga. Hal ini merupakan salah satu teknik yang tepat dalam pemberian pendidikan kesehatan, selain itu setiap pengambilan keputusan yang berhubungan dengan kesehatan ibu dan bayi bidan harus melibatkan keluarga dalam pelaksanaan pemberian asuhan.

3) Pelaksana asuhan kepada pasien dalam hal tindakan perawatan, pemantauan, penanganan masalah, rujukan, dan deteksi dini komplikasi masa nifas.

Dalam menjalankan peran dan tanggung jawabnya, bidan sangat di tuntut kemampuannya dalam menerapkan teori yang sesuai 
kepada pasien. Perkembangan ilmu dan pengetahuan yang paling terbaru yang harus diikuti agar bidan dapat memberikan pelayanan yang berkualitas kepada pasien. Penguasaan bidan dalam pengambilan keputusan yang tepat mengenai kondisi pasien sangatlah penting, terutama menyangkut penentuan kasus rujukan, bidan harus menguasai pengetahuan sehingga dapat mendeteksi dini adanya kelainan dan komplikasi, agar dapat dicegah atau dapat ditangani secara cepat sehingga tidak terjadi suatu keterlambatan.

Asuhan masa nifas diperlukan dalam periode ini karena marupakan masa kritis baik ibu maupun bayinya. Diperkirakan bahwa $60 \%$ kematian ibu termasuk kehamilan terjadi setelah persalinan dan 50\% kematian masa nifas terjadi dalam 24 jam. Oleh karena itu, peran dan tanggung jawab bidan untuk memberikan asuhan kebidanan ibu nifas dengan pemantauan mencegah beberapa kematian ini. Peran bidan antara lain sebagai berikut:

a) Memberikan dukungan secara berkesinambungan selama masa nifas sesuai dengan kebutuhan ibu untuk mengurangi ketegangan fisik dan psikologis selama masa nifas

b) Sebagai promotor hubungan antara ibu dan bayi, serta keluarga

c) Mendorong ibu untuk menyusui bayinya dengan meningkatkan rasa nyaman

d) Membuat kebijakan, perencana program kesehatan yang berkaitan ibu dan anak, serta mampu melakukan kegiatan administrasi

e) Mendeteksi komplikasi dan perlunya rujukan

f) Memberikan konseling untuk ibu dan keluarganya mengenai cara mencegah perdarahan, mengenali tanda-tanda bahaya, menjaga gizi yang baik, serta mempraktikkan kebersihan yang aman 
g) Melakukan manajemen asuhan dengan cara mengumpulkan data, menetapkan diagnosis dan rencana tindakan juga melaksanakannya untuk mempercepat proses pemulihan, serta mencegah komplikasi dengan memenuhi kebutuhan ibu dan bayi selama periode nifas

\subsection{Tahapan Masa Nifas}

Beberapa tahapan masa nifas adalah sebagai berikut:

1. Puerperium dini

Puerperium dini merupakan kepulihan, dimana ibu diperbolehkan berdiri dan berjalan, serta menjalankan aktivitas layaknya wanita normal lainnya.

2. Puerperium intermediate

Puerperium intermediet merupakan masa kepulihan menyeluruh alat-alat genitalia yang lamanya sekitar 6-8 minggu.

3. Puerperium remote

Remote puerperium yakni masa yang diperlukan untuk pulih dan sehat sempurna terutama apabila selama hamil atau persalinan mempunyai komplikasi. Waktu untuk sehat sempurna dapat berlangsung berminggu-minggu, bulanan, bahkan tahunan.

\subsection{Kebijakan Program Nasional Masa Nifas}

Pada kebijakan program nasional masa nifas paling sedikit 4 kali kunjungan yang dilakukan. Hal ini untuk menilai status ibu dan bayi baru lahir serta untuk mencegah, mendeteksi, dan menangani masalah-masalah yang terjadi antara lain sebagai berikut:

1) 6-8 jam setelah persalinan

a. Mencegah pendarahan masa nifas karena atonia uteri

b. Mendeteksi dan merawat penyebab lain pendarahan, rujuk bila pendarahan berlanjut 
c. Memberikan konseling pada ibu atau salah satu anggota keluarga bagaimana mencegah pendarahan masa nifas karena atonia uteri

d. Pemberian ASI awal

e. Melakukan hubungan antara ibu dan bayi baru lahir

f. Menjaga bayi tetap sehat dengan cara mencegah hipotermi Catatan: Jika petugas kesehatan menolong persalinan ia harus tinggal dengan ibu dan bayi baru lahir selama 2 jam post partum, serta hingga dalam keadaan stabil

2) 6 hari setelah persalinan

a. Memastikan involusi uterus berjalan normal, uterus berkontraksi, fundus di bawah umbilicus, tidak ada pendarahan abnormal, tidak ada bau

b. Menilai adanya tanda-tanda demam, infeksi, dan pendarahan abnormal

c. Memastikan ibu mendapatkan cukup makanan, cairan, dan istirahat

d. Memastikan ibu menyusio dengan baik dan tidak memperlihatkan tan-tanda penyulit

e. Memberikan konseling pada ibu mengenai asuhan pada bayi dan tali pusat, serta menjaga bayi tetap hangat dan merawat bayi sehari-hari

3) 2 minggu setelah persalinan

Memastikan rahim sudah kembali normal dengan mengukur dan meraba bagian rahim

4) 6 minggu setelah persalinan

a. Menanyakan pada ibu tentang penyulit- penyulit yang ibu atau bayi alami

b. Memberikan konseling untuk KB secara dini 
Asuhan kebidanan III (Nifas) 9 


\section{BAB 2 : Perubahan Fisiologi Pada Masa Nifas}

\subsection{Perubahan Sistem Reproduksi}

1) Uterus

\section{a. Pengerutan uterus (involusi uteri)}

Pada uterus setelah proses persalinan akan terjadi proses involusi. Proses involusi merupakan proses kembalinya uterus seperti keadaan sebelum hamil dan persalinan. Proses ini dimulai segera setelah plasenta keluar akibat kontraksi otot-otot polos uterus. Pada tahap ketiga persalinan uterus berada di garis tengah, kira-kira $2 \mathrm{~cm}$ di bawah umbilicus dengan bagian fundus bersandar pada promontorium sakralis. Pada saat ini, besar uterus kira-kira sama besar uterus sewaktu usia kehamilan 16 minggu (kira-kira sebesar jeruk asam) dan beratnya kira-kira 100 gr.

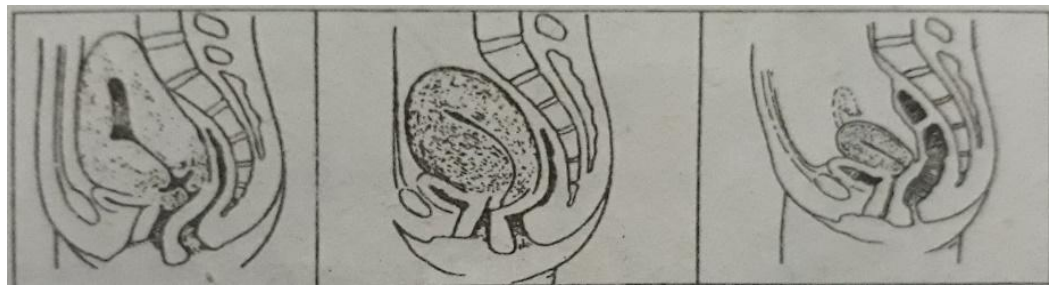

Gambar 2.1 perubahan uterus pada post partum (sumber : Garrey dan Govam, 1974)

Uterus pada waktu hamil penuh beratnya 11 kali berat sebelum hamil, berinvolusi kira-kira 500 gr 1 minggu setelah melahirkan dan 350 gr (11 sampai 12 ons) 2 minggu setelah lahir. Seminggu setelah melahirkan uterus akan berada di dalam panggul. Pada minggu ke-6, beratnya menjadi 50-60 gr. Peningkatan kadar estrogen dan progesteron bertanggung jawab untuk pertumbuhan masif uterus selama hamil. Pertumbuhan uterus prenatal bergantung pada hyperplasia, peningkatan jumlah sel-sel otot dan terjadi hipertrofi sel-sel. Pada masa postpartum 
penurunan kadar hormon-hormon ini menyebabkan terjadinya autolisis, perusakan secara langsung jaringan hipertrofi yang berlebihan. Sel-sel tambahan yang terbentuk selama masa hamil akan menetap. Hal inilah yang menjadi penyebab ukuran uterus sedikit lebih besar setelah hamil. Sedangkan yang dimaksud subinvolusi adalah kegagalan uterus untuk pulih kembali, penyebab subinvolusi yang paling sering adalah karena tertahannya fragmen plasenta dan infeksi.

Perubahan uterus dapat diketahui dengan melakukan pemeriksaan palpasi dengan meraba bagian dari TFU (tinggi fundus uteri)

1. Pada saat bayi lahir, fundus uteri setinggi pusat dengan berat 1000gram.

2. Pada akhir kala III, TFU teraba 2 jari dibawah pusat.

3. Pada 1 minggu post partum, TFU teraba pertengahan pusat simpisis dengan berat 500gram.

4. Pada 2 minggu post partum, TFU teraba diatas simpisis dengan berat 350gram.

5. Pada 6 minggu post partum, fundus uteri mengecil (tidak teraba) dengan berat 50 gram.

Perubahan ini berhubungan erat dengan perubahan muometrium yang bersifat proteolysis

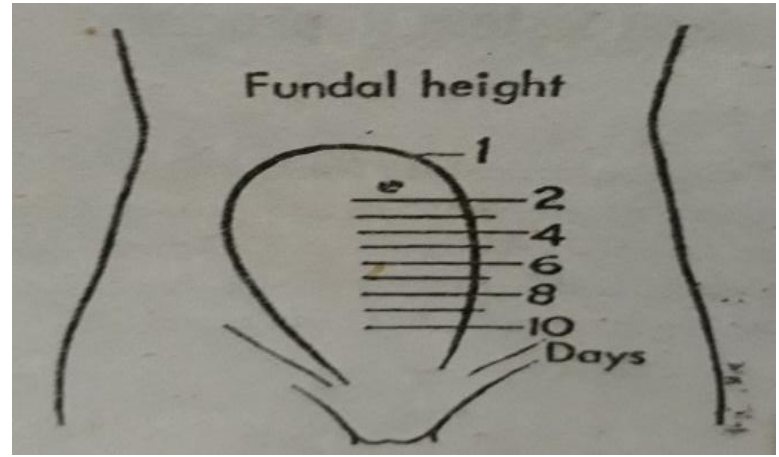

Gambar 4.2 TFU Involusi Uteri (sumber : Garrey dan Govam, 1974) 
Proses involusi uterus adalah sebagai berikut:

1. Iskemia myometrium

Disebabkan oleh kontraksi dan retraksi yang terus-menerus dari uterus setelah pengeluaran plasenta membuat uterus relatif anemia dan menyebabkan serat otot atrofi

2. Autolisis

Autolisis merupakan proses penghancuran diri sendiri yang terjadi di dalam otot uterus. Enzim proteolitik akan memendekkan jaringan otot yang telah sempat mengendur hingga penjangnya 10 kali dari semula dan lebar lima kali dari semula selama kehamilan atau dapat juga dikatakan sebagai perusakan secara langsung jaringan hipertrofi yang berlebihan. Sitoplasma sel yang berlebihan akan tercerna sendiri sehingga tertinggal sebagai jaringan fibro elastic dalam jumlah renik sebagai bukti kehamilan. Hal ini disebabkan karena penurunan hormon estrogen dan progesteron.

3. Atrofi jaringan

Jaringan yang berproliferasi dengan adanya estrogen dalam jumlah besar, kemudian mengalami atrofi sebagai reaksi terhadap pengehentian produksi estrogen yang menyertai pelepasan plasenta. Selain perubahan atrofi pada otot-otot uterus, lapisan desidua akan mengalami atrofi dan terlepas dengan meninggalkan lapisan basal yang akan beregenerasi menjadi endometrium yang baru.

4. Efek oksitosin

Intensitas kontraksi uterus meningkat secara bermakna segera setelah bayi lahir. Hal tersebut diduga terjadi sebagai respon terhadap penurunan volume intrauterine yang sangat besar. Hormon oksitosin yang dilepas dari kelenjar hypofisis memperkuat dan mengatur kontraksi 
uterus, dengan mengompresi pembuluh darah, dan mambantu proses homeostasis. Kontraksi dan retraksi otot uteri akan mengurangi suplai darah ke uterus. Proses ini akan membantu mengurangi bekas luka tempat implantasi plasenta dan mengurangi terjadinya perdarahan. Luka bekas perlekatan plasenta memerlukan waktu 8 minggu untuk sembuh total. Penurunan ukuran uterus terjadi oleh kareana perubahan lokasi uterus ketika turun keluar dari abdomen dan kembali menuju ke organ pelvis.

Selama 1-2 jam pertama post partum, intensitas kontraksi uterus dapat berkurang menjadi teratur. Oleh karena itu penting sekali untuk menjaga dan mempertahankan kontraksi uterus pada masa ini. Suntikan oksitosin biasanya diberikan secara intravena atau intramuskuler, segera setelah bayi lahir. Pemberian ASI segera setelah bayi lahir akan merangsang adanya kontraksi uterus, karena proses hisapan bayi pada payudara dapat memicu pelepasan oksitosin.

Tabel 4.1 Tabel Involusi Uterus

\begin{tabular}{cccc}
\hline NO & Involusi & TFU & Berat Uterus \\
\hline 1 & Bayi lahir & Setinggi pusat & 100 gram \\
\hline 2 & Uri lahir & 2 jari bawa pusat & 750 gram \\
\hline 3 & 1 minggu & $\begin{array}{c}\text { Pertengahan pusat } \\
\text { sympisis }\end{array}$ & 500 gram \\
\hline 4 & 2 minggu & $\begin{array}{c}\text { Tidak teraba di atas } \\
\text { sympisis }\end{array}$ & 350 gram \\
\hline 5 & 6 minggu & Bertambah kecil & 50 gram \\
\hline 6 & 8 minggu & normal & 30 gram \\
\hline
\end{tabular}

\section{b. Involusi tempat implantasi plasenta}


Setelah persalinan, tempat implantasi plasenta merupakan tempat dengan permukaan kasar, tidak rata, dan kira-kira sebesar telapak tangan. Dengan cepat luka ini mengecil, pada akhir minggu ke-2 hanya sebesar $2-4 \mathrm{~cm}$ dan pada akhir nifas $1-2 \mathrm{~cm}$. penyembuhan luka bekas implantasi plasenta khas sekali. Pada permulaan nifas bekas plasenta mengandung banyak pembuluh darah besar yang tersumbat oleh trombus.

Biasanya luka yang sembuh akan menjadi jaringan parut, tetapi luka bekas implantasi plasenta tidak meninggalkan parut. Hal ini disebabkan karena luka ini sembuh dengan cara dilepaskan dari dasarnya tetapi diikuti pertumbuhan endometrium baru dibawah permukaan luka. Endometrium ini tumbuh dari pinggir luka dan juga dari sisa-sisa kelenjar pada dasar luka.

Regenerasi endometrium terjadi di tempat implantasi plasenta selama sekitar 6 minggu. Epitelium berproliferasi meluas ke dalam dari sisi tempat ini dan dari lapisan sekitar uterus serta di bawah tempat implantasi plasenta dari sisa-sisa kelenjar basilar endometrial di dalam desidua basalis. Pertumbuhan kelenjar ini pada hakikatnya mengikis pembuluh darah yang membeku pada tempat implantasi plasenta yang menyebabkannya menjadi terkelupas dan tidak dipakai lagi pada pembuangan lokia.

\section{c. Perubahan Ligamen}

Ligamen-ligamen dan diafragma pelvis, serta fasia yang meregang sewaktu kehamilan dan proses persalinan, setelah janin lahir, berangsur-angsur mengerut kembali seperti sediakala. Tidak jarang ligamentum rotundum menjadi kendur yang mengakibatkan letak uterus menjadi retrofleksi. Tidak jarang pula wanita mengeluh "kandungannya turun" setelah melahirkan oleh karena ligamen, fascia, dan jaringan penunjang alat genitalia menjadi agak kendur. 


\section{d. Perubahan Pada Serviks}

Serviks mengalami involusi bersama-sama uterus. Perubahan yang terjadi pada serviks pada masa postpartum adalah dari bentuk serviks yang akan membuka seperti corong. Bentuk ini disebabkan karena korpus uteri yang sedang kontraksi, sedangkan serviks uteri tidak berkontraksi sehingga seolah-olah pada perbatasan antara korpus dan serviks uteri terbentuk semacam cincin. Warna serviks sendiri merah kehitam-hitaman karena penuh pembuluh darah. Konsistensinya lunak, kadang-kadang terdapat laserasi atau perlukaan kecil. Karena robekan kecil yang terjadi selama berdilatasi selama persalinan, maka serviks tidak akan pernah kembali lagi seperti keadaan sebelum hamil.

Muara serviks yang berdilatasi sampai $10 \mathrm{~cm}$ sewaktu persalinan maka akan menutup seacara bertahap. Setelah 2 jam pasca persalinan, ostium uteri eksternum dapat dilalui oleh 2 jari, pinggir-pinggirnya tidak rata, tetapi retak-retak karena robekan dalam persalinan. Pada akhir minggu pertama hanya dapat dilalui oleh 1 jari saja, dan lingkaran retraksi berhubungan dengan bagian atas dari kanalis servikalis. Pada minggu ke 6 post partum serviks sudah menutup kembali.

\section{e. Lokia}

Dengan adanya involusi uterus, maka lapisan luar dari desidua yang mengelilingi situs plasenta akan menjadi nekrotik. Desidua yang mati akan keluar bersama dengan sisa cairan. Campuran antara darah dan desidua tersebut dinamakan lokia, yang biasanya berwarna merah muda atau putih pucat.

Lokia merupakan ekskresi cairan rahim selama masa nifas dan mempunyai reaksi basa/alkalis yang dapat membuat organisme berkembang lebih cepat daripada kondisi asam yang ada pada vagina normal. Lokia mempunyai bau yang amis 
meskipun tidak terlalu menyengat dan volumenya berbeda-beda pada setiap wanita. Sekret mikroskopik lokia terdiri atas eritrosit, peluruhan desidua, sel epitel, dan bakteri. Lokia mengalami perubahan karena proses involusi.

Pengeluaran lokia dapat dibagi berdasarkan waktu dan warnanya di antaranya sebagai berikut:

1. Lokia rubra/merah (kruenta)

Lokia ini muncul pada hari pertama sampai hari ketiga masa postpartum. Sesuai dengan namanya, warnanya biasanya merah dan mengandung darah dari perobekan/luka pada plasenta dan serabut dari desidua dan chorion. Lokia terdiri atas sel desidua, verniks caseosa, rambut lanugo, sisa mekoneum, dan sisa darah.

2. Lokia sanguinolenta

Lokia ini berwarna merah kecoklatan dan berlendir karena pengaruh plasma darah, pengeluarannya pada hari ke 4 hingga hari ke 7 hari postpartum.

3. Lokia serosa

Lokia ini muncul pada hari ke 7 hingga hari ke 14 pospartum. Warnanya biasanya kekuningan atau kecoklatan. Lokia ini terdiri atas lebih sedikit darah dan lebih banyak serum, juga terdiri atas leukosit dan robekan laserasi plasenta.

4. Lokia alba

Lokia ini muncul pada minggu ke 2 hingga minggu ke 6 postpartum. Warnanya lebih pucat, putih kekuningan, serta lebih banyak mengandung leukosit, sel desidua, sel epitel, selaput lender serviks, dan serabut jaringan yang mati.

Lokia yang menetap pada periode awal postpartum menunjukkan adanya tanda-tanda perdarahan sekunder yang mungkin dapat disebabkan oleh tertinggalnya sisa atau selaput 
plasenta. Lokia alba atau serosa yang berlanjut dapat menandakan adanya endometritis, terutama bila disertai dengan nyeri pada abdomen dan demam.

Bila pengeluaran lokia tidak lancar, maka disebut lochiastasis. Jika lokia tetap berwarna merah setelah 2 minggu ada kemungkinan tertinggalnya sisa plasenta atau karena involusi yang kurang sempurna yang sering disebabkan retroflexio uteri. Lokia mempunyai suatu karakteristik bau yang tidak sama dengan sekret menstrual. Bau yang paling kuat pada lokia serosa dan harus dibedakan juga dengan bau yang menandakan infeksi.

Lokia disekresikan dengan jumlah banyak pada awal jam postpartum yang selanjutnya akan berkurang sejumlah besar sebagai lokia rubra, sejumlah kecil sebagai lokia serosa, dan sejumlah lebih sedikit lagi lokia alba. Umumnya jumlah lokia lebih sedikit bila wanita postpartum berada dalam posisi berbaring daripada berdiri. Hal ini terjadi akibat pembuangan bersatu di vagina bagian atas manakala wanita dalam berbaring dan kemudia akan mengalir keluar manakala dia berdiri. Total jumlah rata-rata pembuangan lokia kira-kira 8-9 oz atau sekita $240-270 \mathrm{ml}$.

\section{2) Perubahan Pada Vulva, Vagina Dan Perineum}

Vulva dan vagina mengalami penekanan, serta peregangan yang sangat besar selama proses persalinan, akibat dari penekanan tersebut vulva dan vagina akan mengalami kekenduran, hingga beberapa hari pasca proses persalinan, pada masa ini terjadi penipisan mukosa vagina dan hilangnya rugae yang diakibatkan karena penurunan estrogen pasca persalinan. Vagina yang semula sangat teregang akan kembali secara bertahap pada ukuran sebelum hamil selama 6-8 minggu 
setelah bayi lahir. Rugae akan kembali terlihat sekitar minggu kempat, walaupun tidak akan menonjol pada wanita nulipara. Pada umumnya rugae akan memipih secara permanen. Mukosa tetap atrofik, pada wanita yang menyusui sekurang-kurangnya sampai menstruasi dimulai kembali. Penebalan mukosa vagina terjadi seiring pemulihan fungsi ovarium.

Pada perineum setelah melahirkan akan menjadi kendur, karena sebelumnya teregang oleh tekanan bayi yang bergerak maju. Post natal hari ke 5 perinium sudah mendapatkan kembali tonusnya walapun tonusnya tidak seperti sebelum hamil. Pada awalnya, introitus vagina mengalami eritematosa dan edematosa, terutama pada daerah episiotomy atau jahitan laserasi. Proses penyembuhan luka episiotomy sama dengan luka operasi lain. Tanda-tanda infeksi (nyeri, merah, panas, dan bengkak) atau tepian insisi tidak saling melekat bisa terjadi. Penyembuhan akan berlangsung dalam dua sampai tiga minggu. Luka jalan lahir yang tidak terlalu luas akan sembuh secara perpriman (sembuh dengan sendirinya), kecuali luka jahitan yang terinfeksi akan menyebabkan sellulitis yang dapat menjalar hingga terjadi sepsis.

\subsection{Perubahan Sistem Pencernaan}

\section{a. Nafsu Makan}

Ibu biasanya merasa lapar segera pada 1-2 jam setelah proses persalinan, Setelah benar-benar pulih dari efek analgesia, anastesia dan keletihan, kebanyakan ibu merasa sangat lapar. Permintaan untuk memperoleh makanan dua kali dari jumlah yang biasa dikonsumsi disertai konsumsi camilan sering ditemukan, untuk pemulihan nafsu makan diperlukan waktu 3-4 hari sebelum faal usus kembali normal. Meskipun kadar progesterone menurun setelah melahirkan, namun asupan makanan juga mengalami penurunan selama 1 atau 2 hari, gerak 
tubuh berkurang dan usus bagian bawah sering kosong jika sebelum melahirkan diberikan enema.

\section{b. Motilitas}

Secara khas, penurunan tonus dan motilitas otot traktus cerna menetap selama waktu yang singkat setelah bayi lahir. Kelebihan analgesia dan anastesia bisa memperlambat pengembalian tonus dan motilitas ke keadaan normal.

\section{c. Pengosongan usus}

Pada masa nifas sering terjadi konstipasi setelah persalinan. hal ini disebabkan karena pada waktu persalinan alat pencernaan mengalami tekanan, dan pasca persalinan tonus otot menurun sehingga menyebabkan kolon menjadi kosong, pengeluaran cairan berlebih pada waktu persalinan, kurangnya asupan makanan, cairan dan aktivitas tubuh.

Buang air besar secara spontan bisa tertunda selama 2-3 hari setelah ibu melahirkan. Ibu nifas seringkali ketakutan saat defekasi karena nyeri yang dirasakannya di perineum akibat laserasi, atau hemoroid. Kebiasaan buang air yang teratur dapat dicapai kembali setelah tonus usus kembali normal. Kebiasaan mengosongkan usus secara regular perlu dilatih kembali untuk merangsang pengosongan usus. Agar dapat buang air besar kembali normal dapat diatasi dengan diet tinggi serat, peningkatan asupan cairan, dan ambulasi awal.

Sistem pencernaan pada masa nifas membutuhkan waktu yang berangsur-angsur untuk kembali normal. Pola makan ibu nifas tidak akan seperti biasa dalam beberapa hari dan perineum ibu akan terasa sakit saat defekasi. Faktor-faktor tersebut mendukung kejadian konstipasi pada ibu nifas pada minggu pertama. Supositoria dibutuhkan untuk membantu eliminasi pada ibu nifas akan tetapi, terjadinya konstipasi juga dapat 
dipengaruhi oleh kurangnya pengetahuan ibu dan kekhawatiran terhadap lukanya akan terbuka apabila ibu buang air besar.

\subsection{Perubahan sistem perkemihan}

Setelah proses persalinan berlangsung, ibu nifas akan kesulitan untuk berkemih dalam 24 jam pertama. Kemungkinan dari penyebab ini adalah terdapar spasme sfinkter dan edema leher kandung kemih yang telah mengalami kompresi (tekanan) antara kepala janin dan tulang pubis selama persalinan berlangsung.

Urin dalam jumlah besar akan dihasilkan dalam 12-36 jam post partum. Kadar hormon estrogen yang bersifat menahan air akan mengalami penurunan yang mencolok (diuresis). Ureter yang berdilatasi akan kembali normal dalam 6 minggu.

Dinding kandung kemih memperlihatkan odem dan hyperemia, kadang-kadang odem trigonum yang dapat menimbulkan alostaksi dari uretra sehingga dapat menjadi retensio urine. Kandung kemih dalam masa nifas menjadi kurang sensitive dan kapasitas bertambah sehingga setiap kali kencing masih tertinggal urin residual (normal kurang lebih $15 \mathrm{cc}$ ). dalam hal ini, sisa urin dan trauma pada kandung kemih sewaktu persalinan dapat beresiko terjadinya infeksi.

\section{Fungsi dan sistem perkemihan}

1. Mencapai hemostasis internal

a. Keseimbangan cairan elektrolit

Cairan yang terdapat dalam tubuh terdiri atas air, dan unsur-unsur yang terlarut didalamnya. Sebanyak $70 \%$ dari air tubuh terletak didalam sel-sel yang dikenal dalam cairan intraselular. Kandungan air sisanya disebut cairan 
ekstraseluler. Cairan ekstraselular dibagi antara plasma darah dan cairan yang langsung memberikan lingkungan segera untuk sel-sel yang disebut cairan interstisial

b. Edema adalah tertimbunnya cairan dalam jaringan akibat gangguan keseimbangan cairan dalam tubuh

c. Dehidrasi adalah kekurangan cairan atau volume air yang terjadi pada tubuh karena pengeluaran yang berlebihan dan tidak diganti

2. Keseimbangan asam basa tubuh

Batas normal ph cairan tubuh adalah 7,35-7,40. Bila ph>,4 disebut alaktosis dan jika ph $<7,35$ disebut asidosis.

3. Mengeluarkan sisa metabolism tubuh, racun, dan zat toksin. Ginjal mengekskresi hasil akhir metabolisme protein yang mengandung nitrogen terutama : urea, asam urat dan kreatinin

\section{Sistem urinarius}

Perubahan hormonal pada masa hamil (kadar steroid yang tinggi) turut menyebabkan peningkatan fungsi ginjal, sedangkan penurunan kadar steroid setelah wanita melahirkan sebagian menjelaskan penyebab penurunan fungsi ginjal selama masa postpartum. Fungsi ginjal kembali normal dalam waktu satu bulan setelah wanita melahirkan. Diperlukan kira-kira 2-8 minggu supaya hipotonia pada kehamilan serta dilatasi ureter dan pelvis ginjal kembali ke keadaan sebelum hamil. Pada sebagian kecil wanita, dilatasi traktus urinarius bisa menetap selama tiga bulan.

\section{Komponen urin}

Glikosuria ginjal diinduksikan oleh kehamilan menghilang. Laktosuria positif pada ibu manyusui merupakan hal yang normal. Blood Urea Nitrogen (BUN) yang meningkat selama pasca partum, merupakan akibat autolisis uterus yang 
berinvolusi. Pemecahan kelebihan protein di dalam sel otot uterus juga menyebabkan proteinuria ringan $(+1)$ salema satu sampai dua hari setelah wanita melahirkan. Hal ini terjadi pada sekitar 50\% wanita. Asetonuria dapat terjadi pada wanita yang tidak mengalami komplikasi persalinan atau setelah suatu persalinan yang lama dan disertai dehidrasi.

\section{Diuresis postpartum}

Dalam 12 jam pasca melahirkan, ibu mulai membuang kelebihan cairan yang tertimbun di jaringan selama ia hamil. Salah satu mekanisme untuk mengurangi cairan teretensi selama masa hamil ialah diaphoresis luas, terutama pada malam hari, selama 2-3 hari pertama setelah melahirkan. Diuresis pascapartum, yang disebabkan oleh penurunan kadar estrogen, hilangnya peningkatan tekanan vena pada tingkat bawah, dan hilangnya peningkatan voume darah akibat kehamilan, merupakan mekanisme tubuh untuk mengatasi kelebihan cairan.

Kehilangan cairan melalui keringat dan peningkatan jumlah urine menyebabkan penurunan berat badan sekitar $2,5 \mathrm{~kg}$ selama masa postpartum. Pengeluaran kelebihan cairan yang tertimbun selama hamil kadang-kadagan disebut kebalikan metabolisme air pada masa hamil (reversal of the water metabolism of pregnancy).

\section{Uretra dan kandung kemih}

Trauma dapat terjadi pada uretra dan kandung kemih selama proses melahirkan, yakni sewatku bayi melewati jalan lahir. Dinding kandung kemih dapat mengalami hyperemia dan edem. Kandung kemih yang edema, terisi penuh, dan hipotonik dapat mengakibatkan over distensi, pengosongan yang tak sempurna, dan urine residual. Hal ini dapat dihindari jika dilakukan asuhan untuk mendorong terjadinya pengosongan kandung kemih Asuhan kebidanan III (Nifas) 22 
bahkan saat tidak merasa untuk berkemih. Pengambilan urine dengan cara bersih atau melalui kateter sering menunjukkan adanya trauma pada kandung kemih.

Uretra dan meatus urinarius bisa juga mengalami edema. Kombinasi trauma akibat kelahiran, peningkatan kapasitas kandung kemih setelah bayi lahir, dan efek konduksi anestesi menyebabkan keinginan untuk berkemih menurun. Selain itu, rasa nyeri pada panggul yang timbul akibat dorongan untuk saat melahirkan, laserasi vagina, atau episiotomy menurunkan atau mengubah reflex berkemih. Penurunan berkemih terjadi seiring diuresis postpartum dapat menyebabkan distensi kandung kemih.

Distensi kandung kemih yang muncul segera setelah wanita melahirkan dapat menyebabkan perdarahan berlebih karena keadaan ini bisa menghambat uterus berkontraksi dengan baik. Pada masa pasca partum tahap lanjut, distensi yang berlebihan ini dapat menyebabkan kandung kemih lebih peka terhadap infeksi sehingga mengganggu proses berkemih normal. Apabila terjadi distensi berlebih pada kandung kemih dapat mengalami kerusakan lebih lanjut (atoni). Dengan mengosongkan kandung kemih secara adekuat, tonus kandung kemih biasanya akan pulih kembali dalam lima sampai tujuh hari setelah bayi lahir.

\subsection{Perubahan Sistem Muskuloskeletal/Diastasis Recti Abdominalis}

Otot-otot uterus berkontraksi segera setelah persalinan. Pembuluh darah yang berada di myometrium uterus akan menjepit, pada proses ini akan menghentikan perdarahan setelah plasenta dilahirkan. Ligamen, diafragma pelvis, serta fasia yang meregang pada waktu persalinan, secara berangsur 
angsur menjadi ciut dan pulih kembali sehingga kadang membuat uterus jatuh kebelakang dan menjadi retrofleksi karena ligamentum rotundum menjadi kendor. Hal ini akan kembali normal pada 6-8 minggu setelah persalinan.

Pada proses persalinan juda dapat menyebabkan putusnya serat-serat elestik kulit dan distensi yang berlangsung lama akibat besarnya uterus pada waktu hamil, dinding abdomen mengendur,. Untuk memulihkan kembali jaringan penunjang genetalia, serta otot dinding perut dan dasar panggul , dianjurkan untuk melakukan latihan tertentu, pada 2 hari post partum sudah dapat dilakukan latihan atau fisioterapi.

\section{System musculoskeletal pada masa nifas}

Adaptasi sistem muskuloskeletal ibu yang terjadi selama hamil berlangsung secara terbalik pada masa pasca partum. Adaptasi ini mencakup hal-hal yang membantu relaksasi dan hipermobilitas sendi dan perubahan pusat gravitasi ibu akibat pembesaran rahim.

a. Dinding perut dan peritoneum

Setelah persalinan, dinding perut longgar karena diregang begitu lama, tetapi biasanya pulih kembali dalam 6 minggu. Kadang pada wanita yang asthenis terjadi diastasis dari otot-otot rectus abdominis sehingga sebagian dari dinding perut di garis tengah hanya terdiri dari peritoneum, fascia tipis dan kulit. Tempat yang lemah ini menonjol kalau berdiri atau mengejan.

b. Kulit abdomen

Kulit abdomen yang melebar selama masa kehamilan tampak melonggar dan mengendur sampai berminggu-minggu atau berbulan-bulan (striae). Melalui latihan postnatal, otot-otot dari dinding abdomen dapat kembali dalam beberapa minggu. 


\section{c. Striae}

Striae pada dinding abdomen tidak dapat menghilang sempurna melainkan membentuk garis lurus yang smar. Ibu post partum memiliki diastasis sehingga terjadi pemisahan muskulus rektus abdominal dapat dilihat pada pengkajian umum, aktivitas, paritas, jarak kehamilan yang dapat menentukan berapa lama tonus otot kembali normal.

d. Perubahan ligament

Ligamen-ligamen dan diafragma pelvis serta fascia yang meragang sewaktu kehamilan dan persalinan, setelah persalianan akan berangsur menciut dan kembali seperti sediakala. Ligamentum rotundum sering menjadi kendor yang dapat mengakibatkan letak usus menjadi retroflexi dan alat genetalia menjadi agak kendor.

\section{Diastasis Recti Abdominis}

Perubahan sistem muskuloskelatal akan kembali secara bertahap seperti pada keaadaan sebelum hamil dalam periode waktu selama 3 bulan setelah persalinan. Kembalinya tonus otot dasar panggung dan abdomen pulih secara bersamaan. Pemulihan pada masa nifas ini dapat berlangsung normal atau atau cepat dengan melakukan latihan fisik ringan, sepeti senam nifas. Otot rectus abdominis kemungkinan akan tergang $(>2,5 \mathrm{~cm})$ pada garis tengah/umbilikus, pada kondisi ini dikenal dengan Diastasis Recti Abdominis (DRA), karena pada kondisi tersebut linea alba terjadi peregangan mekanis pada dinding abdomen yang berlebihan, hal ini juga dikarenakan adanya pengaruh hormone ibu. 


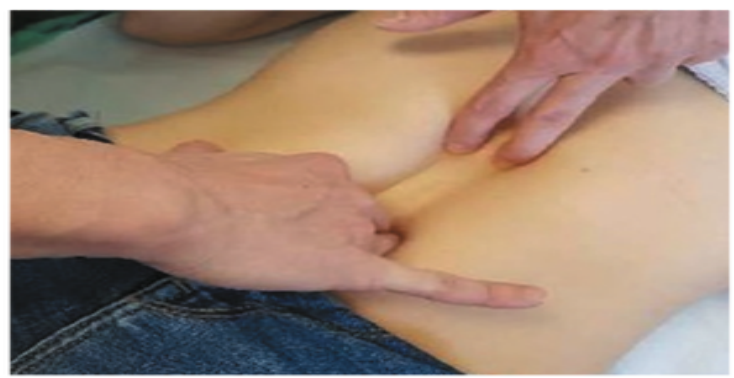

Figure 1. Clinical picture of DRA, a 30-year-old patient, 6 months postpartum (from the authors' own archives, reprinted with the patient's permission)

\section{Gambar 3.1. Diaktasis Rekti Abdominal}

Diaktasis Rekti Abdominal sering muncul pada grandemultipara, kehamilan ganda, polihidramnion, dan bayi dengan makrosomia, kelemahan abdomen dan postur yang salah. Peregangan yang berlebihan dan berlangsung lama ini menyebabkan serat-serat elastis kulit yang putus sehingga pada masa nifas dinding abdomen cenderung lunak dan kendur. Senam nifas dapat membantu memulihkan ligament, dasar panggung, otot-otot dinding perut dan jaringan penunjang lainnya.

Dampak dari diaktasis rekti ini dapat menyebabkan hernia epigastric dan umbilikalis. Oleh karena itu pemeriksaan terhadap rektus abdominal perlu dilakukan pada ibu nifas, sehingga dapat diberikan penanganan secara cepat dan tepat.

\subsection{Perubahan Sistem Endokrin}

Perubahan sistem endokrin yang terjadi pada masa nifas adalah perubahan kadar hormon dalam tubuh. Adapaun kadar hormon yang mengalami perubahan pada ibu nifas adalah hormone estrogen dan progesterone, hormone oksitosin dan prolactin. Hormon estrogen dan progesterone menurun secara drastis, sehingga terjadi peningkatan kadar hormone prolactin dan oksitosin. 
Hormon oksitosin berperan dalam proses involusi uteri dan juga memancarkan ASI, sedangkan hormone prolactin berfungsi untuk memproduksi ASI. Keadaan ini membuat proses laktasi dapat berjalan dengan baik. Jadi semua ibu nifas seharusnya dapat menjalani proses laktasi dengan baik dan sanggup memberikan ASI eksklusif pada bayinya.

Hormone lain yang mengalami perubahan adalah hormone plasenta. Hormone plasenta menurun segera setelah plasenta lahir. Human Chorionic Gonadotropin (HCG) menurun dengan cepat dan menetap sampai $10 \%$ pada 3 jam pertama hingga hari ke tujuh postpartum. Hal yang mempengaruhi perubahan sistem endokrin :

a. Hormon plasenta

Hormone plasenta menurun dengan cepat setelah persalinan, HCG (Human Chorionic Gonodotropin) menurun dengan cepat dan menetap sampai $10 \%$ dalam 3 jam hingga hari ke-7 post partum dan sebagai onset pemenuhan mamae pada hari ke-3 post partum.

b. Hormon pituitary

Prolaktin datrah akan meningkat dengan cepat. Pada wanita yang tidak menyusui, prolactin menurun dalam waktu 2 minggu. FSH dan LH akan meningkat pada fase konsentrasi folikuler (minggu ke-3) dan LH tetap rendah hingga ovulasi terjadi.

c. Hypotalamik pituitary ovarium

Lamanya seorang wanita mendapat menstruasi juga dipengaruhi oleh factor menyusui. Seringkali menstruasi pertama ini bersifat anovulasi karena rendahnya kadar estrogen dan progesterone. 


\section{d. Kadar estrogen}

Setelah persalinan, terjadi penurunan kadar estrogen yang bermakna sehingga aktivitas prolaktin yang juga sedang meningkat dapat memengaruhi kelenjar mamae dalam menghasilkan ASI

\subsection{Perubahan Tanda-Tanda Vital}

Beberapa perubahan tanda-tanda vital biasa terlihat jika wanita dalam keadaan normal, peningkatan kecil sementara, baik peningkatan tekanan darah systole maupun diastole dapat timbul dan berlangsung selama sekitar 4 hari setelah wanita melahirkan. Fungsi pernapasan kembail pada fungsi saat wanita tidak hamil yaitu pada bulan keenam setelah wanita melahirkan. Setelah rahim kosong, diafragma menurun, aksis jantung kembali normal, serta impuls dan EKG kembali normal.

\section{a. Suhu Badan}

Satu hari (24 jam) post partum suhu badan akan naik sedikit (37,5-38 $\left.{ }^{\circ} \mathrm{C}\right)$ sebagai akibat kerja keras waktu melahirkan, kehilangan cairan, dan kelelahan. Apabila keadaan normal, suhu badan menjadi biasa. Biasanya pada hari ke-3 suhu badan naik lagi kaena ada pembentukan ASI dan payudara menjadi bengka, berwarna merah karena banyaknya ASI. Bila suhu tidak turun kemungkinan adanya infeksi pada endometrium, mastisis, traktu genitalis, atau sistem lain.

b. Nadi

Denyut nadi normal pada orang dewasa 60-80 kali per menit. Sehabis melahirkan biasanya denyut nadi itu akan lebih cepat.

c. Tekanan Darah

Biasanya tidak berubah, kemungkinan tekanan darah akan rendah setelah melahirkan karena ada pendarahan. Tekanan 
darah tinggi pada postpartum dapat menandakan terjadinya preeklamsia post partum

d. Pernapasan

Keadaan pernapasan selalu berhubugan dengan keadaan suhu dan denyut nadi. Bila suhu nadi tidak normal, pernapasan juga akan mengikutinya, kecuali apabila ada gangguan khusus pada saluran napas.

\subsection{Perubahan Sistem Kardiovaskular}

\section{Volume Darah}

Perubahan volume darah bergantung pada beberapa factor, misalnya kehilangan darah selama melahirkan dan mobilisasi, serta pengeluaran cairan ekstravaskuler (edema fisiologis). Kehilangan darah merupakan akibat penurunan volume darah total yang cepat, tetapi terbatas. Setelah itu terjadi perpindahan normal cairan tubuh yang menyebabkan volume darah menurun dengan lambat. Pada minggu ke-3 dan ke-4 setelah bayi lahir, volume darah biasanya menurun sapai mencapai volume darah sebelum hamil. Pada persalinan per vaginam, ibu kehilangan darah sekitar 300-400 cc. bila kelahiran melalui SC, maka kehilangan darah dapat 2 kali lipat. Perubahan terdiri atas volume darah dan hematokrit (haemoconcentration). Pada persalinan per vaginam, hematocrit akan naik, sedangkan pada SC, hematocrit cenderung stabil dan kembali normal setelah 4-6 minggu.

Tiga perubahan fisiologi pascapartum yang terjadi pada wanita antara lain sebagai berikut:

1. Hilangnya sirkulasi uteroplasenta yang mengurangi ukuran pembuluh darah maternal $10-15 \%$

2. Hilangnya fungsi endokrin plasenta yang menghilangkan stimulus vasodilatasi 
3. Terjadinya mobilisasi air ekstravaskular yang disimpan selama wanita hamil

\section{Curah Jantung}

Denyut jantung, volume sekuncup, dan curah jantung meningkat sepanjang masa hamil. Segera setalah wanita melahirkan, keadaan ini meningkat bahkan lebih tinggi selama 30-60 menit karena darah yang biasanya melintasi sirkulasi uteroplasenta tiba-tiba kembali ke sirkulasi umum. Nilai ini meningkat pada semua jenis kelahiran.

\subsection{Perubahan Sistem Hematologi}

Selama kehamilan, kadar fibrinogen dan plasma, serta faktor-faktor pembekuan darah meningkat. Pada hari pertama postpartum, kadar fibrinogen dan plasma akan sedikit menurun, tetapi darah lebih mengental dengan peningkatan viskositas sehingga meningkatkan faktor pembekuan darah. Leukositosis yang meningkat di mana jumlah sel darah putih dapat mencapai 15.000 selama persalinan akan tetap tinggi dalam beberapa hari pertama dari masa postpartum. Jumlah sel darah putih tersebut masih biasa naik sampai 25.000-30.000 tanpa adanya kondisi patologi jika wanita tersebut mengalami persalinan lama.

Jumlah hemoglobin, hematocrit, dan eritrosit akan sangat bervariasi pada awal-awal masa postpartum sebagai akibat dari volume darah. Volume plasenta dan tingkat volume darah yang berubah-ubah akan dipengaruhi oleh status gizi wanita tersebut. Kira-kira selama kelahiran dan masa postpartum terjadi kehilangan darah sekitar 200-500 ml. penurunan volume dan peningkatan sel darah pada kehamilan diasosiasikan dengan peningkatan hematokrit dan hemoglobin pada hari ke-3 sampai 
ke-7 pospartum dan akan kembali normal dalam 4-5 minggu postpartum.

\section{Perubahan Komponen Darah}

Pada masa nifas terjadi perubahan komponen darah, misalnya jumlah sel darah putih akan bertambah banyak. Jumlah sel darah merah dan $\mathrm{Hb}$ akan berfluktuasi, namun dalam 1 minggu pasca persalinan biasanya semuanya akan kembali pada keadaan semula. Curah jantung atau jumlah darah yang dipompa oleh jantung akan tetapi tinggi pada awal masa nifas dan dalam 2 minggu akan kembali pada keadaan normal. 


\section{BAB 3 : Proses Adaptasi Psikologi Pada Masa Nifas}

\subsection{Adaptasi Psikologis Ibu Masa Nifas}

Pengalaman menjadi orang tua khususnya menjadi seorang ibu tidaklah selalu merupakan suatu hal yang menyenangkan bagi setiap wanita atau pasangan suami istri. Realisasi tanggung jawab sebagai seorang ibu merupakan faktor pemicu munculnya gangguan emosi, intelektual, dan tingkah laku pada seorang wanita. Beberapa penyesuaian dibutuhkan oleh wanita dalam menghadapi aktivitas dan peran barunya sebagai seorang ibu. Sebagian wanita berhasil menyesuaikan diri dengan baik, tetapi sebagian lainnya tidak berhasil menyesuaikan diri dan mengalami gangguan-gangguan psikologis dengan berbagai gejala atau sindrom yang oleh para peneliti dan klinisi disebut post-partum blues.

Banyak faktor yang diduga berperan pada sindrom post-partum blues, salah satu yang penting adalah kecukupan dukungan sosial dari lingkungannya (terutama suami). Kurangnya dukungan sosial dari keluarga dan teman khususnya dukungan suami selama peiode pasca salin (nifas) diduga kuat merupakan factor penting dalam terjadinya post-pastum blues. Ada banyak perubahan yang telah terjadi di masa 9 bulan saat kehamilan, dan bahkan bisa lebih yang terjadi pada masa nifas, bahkan mungkin merasa sedikit ditinggalkan atau dipisahkan dari lingkungannya.

Banyak hal yang dapat menambah beban hingga membuat seorang wanita merasa down. Banyak juga wanita yang merasa tertekan setelah melahirkan, sebenarnya hal tersebut adalah wajar. Perubahan peran seorang ibu semakin besar dengan lahirnya bayi yang baru lahir. Dukungan positif dan perhatian dari seluruh anggota keluarga lainnya merupakan suatu hal yang dibutuhkan oleh ibu. 
Dalam menjalani adaptasi masa nifas, sebagian ibu dapat mengalami fase-fase sebagai berikut:

\section{Fase taking in}

Fase taking in yaitu periode ketergantungan berlangsung pada hari pertama sampai hari kedua setelah melahirkan. Ibu baru umumnya pasif dan tergantung, perhatiannya tertuju pada kekhawatiran akan tubuhnya. Pengalaman selama proses persalinan berulang kali diceritakannya. Hal ini membuat ibu cenderung menjadi pasif terhadap lingkungannya. Kemampuan mendengarkan (listening skills) dan menyediakan waktu yang cukup merupakan dukungan yang tidak ternilai bagi ibu. Kehadiran suami dan keluarga sangat diperlukan pada fase ini. Petugas kesehatan dapat menganjurkan kepada suami dan keluarga untuk memberikan dukungan moril dan menyediakan waktu untuk mendengarkan semua yang disampaikan oleh ibu agar dia dapat melewati fase ini dengan baik.

Gangguan psikologis yang mungkin dirasakan ibu pada fase ini adalah sebagai berikut:

a. Kekecewaan karena tidak mendapatkan apa yang diinginkan tentang bayinya misalkan: jenis kelamin tertentu, warna kulit, dan sebagainya

b. Ketidaknyamanan sebagai akibat dari perubahan perubahan fisik yang dialami ibu misalnya rasa mules akibat dari kontraksi rahim, payudara bengkak, akibat luka jahitan, dan sebagainya

c. Rasa bersalah karena belum bisa menyusui bayinya

d. Suami atau keluarga yang mengkritik ibu tentang cara merawat bayinya dan cenderung melihat saja tanpa membantu. Ibu akan merasa tidak nyaman karena 
sebenarnya hal tersebut bukan hanya tanggung jawab ibu saja, tetapi tanggung jawab bersama.

Pada saat ini tidur tanpa gangguan sangat penting untuk mengurangi gangguan fisik dan psikologis yang dapat diakibatkan karena kurang istirahat, selain itu peningkatan nutrisi dibutuhkan untuk mempercepat pemulihan dan penyembuhan luka, serta persiapan proses laktasi aktif.

Dalam memberikan asuhan, bidan harus dapat memfasilitasi kebutuhan psikologis ibu. Pada tahap ini bidan dapat menjadi pendengar yang baik ketika ibu menceritakan pengalamannya. Berikan juga dukungan mental atau apresiasi atas hasil perjuangan ibu dalam melahirkan bayinya. Bidan diharapkan dapat menciptakan suasana yang nyaman bagi ibu sehingga ibu dapat dengan leluasa menceritakan permasalahan yang sedang dihadapi kepada bidan. Dalam hal ini sering kali terjadi kesalahan dalam perawatan yang dilakukan kepada pasien dan bayinya akibat kurangnya jalinan komunikasi yang baik antara pasien dengan bidan.

2. Fase taking hold

Fase taking hold adalah fase/periode yang berlangsung antara 3-10 hari setelah melahirkan. Pada fase ini, ibu merasa khawatir akan ketidakmampuannya dan rasa tanggung jawabnya dalam merawat bayi. Ibu memiliki perasaan yang sangat sensitif sehingga mudah tersinggung dan gampang marah sehingga kita perlu berhati-hati dalam berkomunikasi dengan ibu.

Pada fase ini ibu memerlukan dukungan karena saat ini merupakan kesempatan yang baik untuk menerima berbagai masukan dalam merawat diri dan bayinya sehingga timbul percaya diri. Tugas sebagai tenaga kesehatan yakni mengajarkan 
cara merawat bayi, cara menyusui yang benar, cara merawat luka jahitan, mengajarkan senam nifas, memberikan pendidikan kesehatan yang diperlukan ibu seperti gizi, istirahat, kebersihan diri, dan lain-lain.

\section{Fase letting go}

Fase letting go merupakan fase menerima tanggung jawab akan peran barunya yang berlangung sepuluh hari setelah melahirkan. Ibu sudah dapat menyesuaikan diri, merawat diri dan bayinya, serta kepercayaan dirinya sudah meningkat. Pendidian kesehatan yang kita berikan pada fase sebelumnya akan sangat berguna bagi ibu agar lebih mandiri dalam memenuhi kebutuhan diri dan bayinya.

Dukungan dari suami dan keluarga masih sangat diperlukan ibu. Suami dan keluarga dapat membantu merawat bayi, mengerjakan urusan rumah tangga sehingga ibu tidak terlalu lelah dan terbebani. Ibu memerlukan istirahat yang cukup sehinga mendapatkan kondisi fisik yang bagus untuk dapat merawat bayinya.

Pada periode ini ibu mengambil tanggung jawab terhadap perawatan bayi dan harus beradaptasi dengan segala kebutuhan bayi sangat bergantung pada ibu, hal ini menyebabkan berkurangnya hak ibu, kebebasan serta hubungan sosial. Jika hal ini tidak dapat dilalui dengan baik maka dapat menyebabkan terjadinya post partum blues dan depresi post partum.

Faktor-faktor yang mempengaruhi suksesnya masa transisi ke masa menjadi orang tua pada saat post partum, antara lain :

1) Respon dan dukungan keluarga dan teman.

Bagi ibu post partum, apalagi pada ibu yang pertama kali melahirkan akan sangat membutuhkan dukungan orang-orang terdekatnya karena ia belum sepenuhnya Asuhan kebidanan III (Nifas) 35 
berada pada kondisi stabil, baik fisik maupun psikologisnya. la masih sangat asing dengan perubahan peran barunya yang begitu fantastis terjadi dalam waktu yang begitu cepat, yakni peran sebagai "ibu"

Dengan respon positif dari lingkungan, akan mempercepat proses adaptasi peran ini sehingga akan memudahkan bagi bidan untuk memberikan asuhan yang sehat.

2) Hubungan dari pengalaman melahirkan terhadap harapan dan aspirasi

Hal yang dialami oleh ibu ketika melahirkan akan sangat mewarnai alam perasaannya terhadap perannya sebagai ibu. la akhirnya menjadi tahu bahwa begitu beratnya ia harus berjuang untuk melahirkan bayinya dan hal tersebut akan memperkarya pengalaman hidupnya untuk lebih dewasa. Banyak kasus terjadi, setelah ibu melahirkan anaknya yang pertama, ia bertekad untuk lebih meningkatkan kualitas hubungannya dengan ibunya.

3) Pengalaman melahirkan dan membesarkan anak yang lalu. Walaupun bukan kelahiran anak berikutnya bukan pengalaman pertama, namun kebutuhan dukungan positif dari lingkungannya tidak berbeda dengan ibu yang melahirkan anak yang pertama. Hanya perbedaannya adalah teknik penyampaian dukungan yang diberikan lebih kepada support dan apresiasi dari keberhasilannya dalam melewati saat-saat sulit pada persalinan yang lalu.

4) Pengaruh budaya

Adanya adat istiadat yang dianut oleh lingkungan dan keluarga sedikit lebih banyak akan mempengaruhi keberhasilan ibu dalam melewati saat transisi ini, apalagi jika ada hal yang tidak sinkron antara arahan dari tenaga kesehatan dengan budaya yang di anut pada lingkungan ibu. 
Dalam hal ini bidan harus bijaksana dalam menyikapi, namun tidak mengurangi kualitas asuhan yang harus diberikan. Keterlibatan keluarga dari awal dalam menentukan bentuk asuhan dan perawatan yang harus diberikan pada ibu dan bayi akan memudahkan bidan dalam pemberian asuhan.

\subsection{Postpartum Blues}

Melahirkan merupakan salah satu hal yang paling penting dari peristiwa-peristiwa paling bahagia dalam hidup seorang wanita. Akan tetapi mengapa sebagian wanita merasa sedih dengan kelahiran bayinya, Sebanyak $80 \%$ dari perempuan mengalami gangguan suasana hati setelah kehamilan ("melahirkan"). Mereka merasa kecewa, sendirian, takut, atau tidak mencintai bayi mereka, dan merasa bersalah karena perasaan ini.

Postpartum Blues atau yang sering juga disebut maternity blues atau sindrom ibu baru, dimengerti sebagai suatu sindrom gangguan efek ringan pada minggu pertama setelah persalinan dengan ditandai gejala-gejala berikut ini:

1. Reaksi depresi/sedih/disforia

2. Sering menangis

3. Mudah tersinggung

4. Cemas

5. Labilitas perasaan

6. Cenderung menyalahkan diri sendiri

7. Gangguan tidar dan nafsu makan

8. Kelelahan

9. Mudah sedih

10. Cepat marah

11. Mood mudah berubah, cepat menjadi sedih, dan cepat pula menjadi gembira

12. Perasaan terjebak dan juga marah terhadap pasangannya dan bayinya 
13. Perasaan bersalah

14. Pelupa

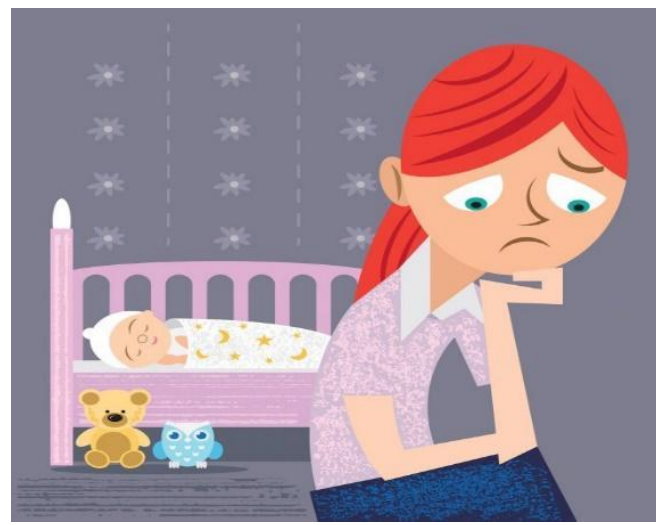

Gambar 5.1 Postpartum Blues

Puncak dari postpartum blues ini 3-5 hari setelah melahirkan dan berlangsung dari beberapa hari sampai 2 minggu. Postpartum blues dapat terjadi pada siapapun, maka diharapkan tidak dianggap sebagai penyakit. Postpartum blues tidak mengganggu kemampuan seorang wanita merawat bayinya sehingga ibu dengan postpartum blues masih bisa merawat bayinya. Postpartum blues tidak berhubungan dengan penyakit mental sebelumnya dan tidak disebabkan oleh stres. Namun stres dan riwayat depresi dapat mempengaruhi kejadian postpartum blues terus menjadi depresi besar, oleh karena itu kejadian postpartum blues harus segera ditindaklajuti.

Penyebab timbulnya postpartum blues sebagai berikut:

1. Faktor hormonal, berupa perubahan kadar estrogen, progesterone, prolactin, serta estriol yang terlalu rendah. kadar estrogen turun secara tajam setelah melahirkan dan ternyata 
estrogen memiliki efek supresi aktivitas enzim non-adrenalin maupun serotin yang berperan dalam suasana hati dan kejadian depresi

2. Ketidaknyamanan fisik yang dialami sehingga menimbulkan perasaan emosi pada wanita pasca melahirkan, misalnya rasa sakit akibat luka jahit atau bengkak pada payudara

3. Ketidakmampuan beradaptasi pada perubahan-perubahan yang terjadi

4. Faktor umur dan jumlah anak

5. Pengalaman dan proses kehamilan dan persalinannya

6. Latar belakang sikososial wanita tersebut misalnya, tingkat pendidikan, kehamilan yang tidak diinginkan, status perkawinan, atau riwayat gangguan jiwa pada wanita tersebut

7. Dukungan yang diberikan dari lingkungan misalnya dari suami, orang tua, dan keluarga

8. Stres yang dialami oleh wanita itu sendiri misalnya: karena belum bisa menyusui bayinya, rasa bosan terhadap rutinitas barunya

9. Kelelahan pasca bersalin

10. Ketidaksiapan terhadap perubahan peran yang terjadi pada wanita tersebut

11. Rasa memiliki bayinya terlalu dalam sehingga takut yang belebihan akan kehilangan bayinya

12. Masalah kecemburuan dari anak yang terdahulunya

Beberapa cara mengatasi postpartum blues adalah sebagai berikut:

1. Persiapan diri yang baik selama kehamilan untuk menghadapi masa nifas

2. Komunikasikan segala permasalahan atau hal yang ingin disampaikan

3. Selalu membicarakan rasa cemas yang dialami 
4. Bersikap tulus serta ikhlas terhadap apa yang telah dialami dan berusaha melakukan peran barunya sebagai seorang ibu yang baik

5. Cukup istirahat

6. Menghindari perubahan hidup yang drastis

7. Berolahraga ringan

8. Berikan dukungan dari keluarga, suamu, atau saudara

9. Konsultasikan kepada tenaga kesehatan atau orang yang professional agar dapat memfasilitasi faktor risiko lainnya selama masa nifas dan membantu dalam melakukan upaya pengawasan

\subsection{Edinburg Postnatal Depression Scale (EPSD)}

Di luar negeri tindakan skrining untuk mendeteksi gangguan mood/depresi sudah merupakan acuan pelayanan pascabersalin yang rutin, untuk dapat melakukan asuhan tersebut dapat digunakan alat bantu berupa Edinburg Postnatal Depression Scale (EPSD) yaitu kuesioner dengan validitas yang telah teruji yang dapat mengukur intensitas perubahan suasana depresi selama 7 hari pasca bersalin.

Pertanyaan-pertanyaan berhubungan dengan labilitas perasaan kecemasan, perasaan bersalah, serta mencakup hal-hal yang mencakup post-partum blues. Kuesioner ini terdapat 10 pertanyaan di mana setiap pertanyaan memiliki 4 pilihan jawaban yang mempunyai nilai atau skor yang harus dilipih salah satu yang sesuai dengan gradasi perasaan yang dirasakan ibu setelah bersalin saat itu.

Pertanyaan tersebut harus dijawab sendiri oleh ibu dan rata-rata harus diselesaikan dalam waktu 5 menit. Kuesioner tersebut telah teruji validitasnya di beberapa negara seperti Belanda, Swedia, Australia, Indonesia, dan Italia. EPSD dapat dipergunakan pada 
minggu pertama setelah bersalin, apabila hasilnya meragukan dapat diulangi pengisiannya 2 minggu kemudian.

\subsection{Kesedihan Dan Duka Cita/Depresi}

Penelitian menunjukkan $10 \%$ ibu mengalami depresi setelah melahirkan dan 10\%-nya saja yang tidak mengalami perubahan emosi. Keadaan ini berlangsung antara 3-6 bulan bahkan pada beberapa kasus terjadi selama 1 tahun pertama kehidupan bayi. Penyebab depresi terjadi karena reaksi terhadap rasa sakit yang muncul saat melahirkan dan karena sebab-sebab yang kompleks lainnya.

Dalam bahasan kali ini, digunakan istilah "berduka" yang di artikan sebagai respon psikologis terhadap Kehilangan. Proses berduka sangat bervariasi, tergantung dari apa yang hilang serta presepsi dan keterlibatan individu terhadap apapun yang hilang. Seberapa kehilangan tergantung dari presepsi individu yang merasakan kehilangan.

Kehilangan maternitas termasuk hal yang dialami oleh wanita yang mengalami infertilitas (wanita yang tidak mampu hamil atau tidak mampu mempertahankan kehamilannya), yang mendapatkan bayinya hidup, tapi kemudian Kehilangan harapan (prematuritas atau kecacatan congenital), dan kehilangan yang dibahas sebgai penyebab post partum blues (Kehilangan keintiman internal dengan bayinya dan hilangnya perhatian). Kehilangan lain yang penting, tapi sering dilupakan adalah perubahan hubungan eksklusif antara suami dan istri menjadin kelompok tiga orang, yakni ayah-ibu dan anak. Tidak dianjurkan untuk rawat gabung (rooming in) dengan bayinya pada ibu yang menderita depresi berat.

Beberapa gejala-gejala depresi berat adalah sebagai berikut: 
1. Perubahan pada mood

2. Gangguan pada pola tidur dan pola makan

3. Perubahan mental dan libido

4. Dapat pula muncul fobia, serta ketakutan akan menyakiti dirinya sendiri dan bayinya

Depresi berat akan terjadi biasanya pada wanita/keluarga yang pernah mempunyai riwayat kelainan psikiatrik. Selain itu, kemungkinan dapat terjadi pada kehamilan selanjutnya.

Berikut ini adalah penatalaksanaan depresi berat:

1. Dukungan keluarga dan lingkungan sekitar

2. Terapi psikologis dari psikiater

3. Kolaborasi dengan dokter untuk memberikan antidepresan (perlu diperhatikan pemberian anti depresan pada wanita hamil dan menyusui)

4. Jangan ditinggal sendirian di rumah

5. Jika diperlukan lakukan perawatan di rumah sakit

Tahap duka cita dibagi menjadi tiga yakni :

1) Tahap Syok

Tahap ini merupakan tahap awal dari kehilangan. Manifestasi perilaku meliputi penyangkalan, ketidakpercayaan, marah, jengkel, katakutan, kecemasan, rasa bersalah, kekosongan, kesendirian, kesedihan, isolasi, mati rasa, menangis, introversi (memikirkan dirinya sendiri), tidak rasional, bermusuhan, kebencian, kegetiran, kewaspadaan akut, kurang inisiatif, bermusuhan, mengasingkan diri, berkhianat, frustasi, dan kurang kosentrasi. Manifestasi fisik meliputi gelombang distress somatic yang berlangsung selama 20-60 menit, menghela nafas nafas panjang, penurunan berat badan, anoreksia, tidur tidak tenang, keletihan, penampilan kurus dan tampak lesu, rasa penuh ditenggorokan, tersedak, napas pendek, mengeluh 
tersiksa karena nyeri di dada, gemetaran internal, kelemahan umum, dan kelemahan pada tungkai.

2) Tahap penderitaan (fase realitas)

Penerimaan terhadap fakta kehilangan dan upaya penyesuaian terhadap realitas yang harus ia lakukan terjadi selama periode ini. Contohnya, orang yang berduka akan menyesuaikan diri dengan lingkungannya tanpa kehadiran orang yang yang disayanginya. Dalam tahap ini ia akan selalu terkenang dengan orang yang di cintainya sehingga kadang akan muncul perasaan marah, rasa bersalah, dan takut. Nyeri karena kehilangan akan dirasakan secara menyeluruh, dalam realitas yang memanjang dan dalam ingatan setiap hari. Menangis adalah salah satu pelepasan emosi yang umum. Selama masa ini kehidupan orang yang berduka akan terus berlanjut. Saat individu terus melanjutkan tugasnya dalam kondisi berduka, dominasi kehilangannya secara bertahap berubah menjadi kecemasan terhadap masa depan.

3) Tahap resolusi (fase menentukan hubungan yang bermakna) Selama periode ini, orang yang berduka menerima kehilangan, penyesuaian telah komplet, dan individu kembali kembali pada fungsinya secara penuh. Kemajuan ini berhasil karena adanya penanaman kembali emosi seseorang pada hubungan lain yang lebih bermakna. Penanaman kembali emosi tidak berarti posisi orang yang hilang telah tergantikan, tetapi bahwa individu lebih mampu dalam menanamkan dan membentuk hubungan yang lebih bermakna dengan resolusi, serta perilaku orang tersebut telah kembali menjadi pilihan yang bebas, mengingat selama menderita perilaku ditentukan oleh nilai-nilai sosial atau kegelisahan internal.

Bidan dapat membantu untuk melalui proses berduka, sekaligus memfasilitasi kedekatan anak yang tidak sempurna, dengan menyediakan lingkungan yang aman, nyaman, mendengarkan, 
sabar, memfasilitasi ventilasi perasaan negatif mereka dan permusuhan, serta penolakan mereka terhadap bayinya.

Orang terdekat dirumah juga harus diberitahu mengenai kehilanagan sehingga mereka mendapatkan penjelasan yang jujur. Jika tidak mereka mungkin akan berpikir bahwa merekalah penyebab masalah yang mengerikan dan tidak diketahui tersebut. Saudara kandung perlu diyakinkan kembali bahwa apapun yang terjadi bukan kesalahan mereka dan bahwa mereka tetap penting, di cintai, dan dirawat.

Tanggung jawab bidan adalah membagi informasi tersebut dengan keluarga sehingga dapat segera merasakan jika sesuatu tidak berjalan dengan baik. Pada peristiwa kematian, ibu tidak mendengarkan suara bayi dan ibu mempunyai hak untuk mendapatkan informasi sebanyak mungkin dari bidan pada saat itu juga. Kejujuran dan realitas akan jauh lebih baik menghibur daripada keyakinan yang palsu atau kerahasiaan. 


\section{BAB 4 : Respon Bayi Baru Lahir}

\subsection{Bounding Attachment}

Kelahiran adalah sebuah momen yang dapat membentuk suatu ikatan antara ibu dan bayinya. Pada saat bayi dilahirkan adalah saat yang sangat menakjubkan bagi seorang ibu ketika ia dapat melihat, memegang, dan memberikan ASI pada bayinya untuk pertama kali. Pada masa tenang setelah malahirkan, di saat ibu merasa rileks, memberikan peluang ide untuk memulai pembentukan ikatan batin. Seorang bayi yang baru lahir mempunyai kemampuan yang banyak misalnya bayi dapat mencium, merasa, mendengar, dan melihat. Kulit mereka sangat sensitif terhadap suhu dan sentuhan, dan selama satu jam pertama setelah melahirkan mereka sangat waspada, serta siap untuk mempelajari dunia baru mereka. Jika tidak ada komplikasi yang serius, setelah bayi lahir dapat langsung diletakkan diatas perut ibu. Kontak segera ini akan sangat bermanfaat baik bagi ibu maupun bayinya. Kontak ibu dan bayi telah terjadi sejak masa kehamilan dan saat persalinan ikatan tersebut akan semakin kuat. Bidan sebagai tenaga kesehatan dapat memfasilitasi perilaku ikatan awal ini dengan cara menyediakan sebuah lingkungan yang mendukung sehingga kontak dan interaksi yang baik dari orang tua kepada anak dapat terjadi.

\section{Pengertian}

Menurut Brazelton (1978), bonding merupakan suatu ketertarikan mutual pertama antara individu, misalnya antara orang tua dan anak, saat pertama kali mereka bertemu. Attachment adalah suatu perasaan menyayangi atau loyalitas yang mengikat individu dengan individu lain. Sementara itu, menurut Nelson dan May (1996) attachment merupakan ikatan antara 
individu meliputi pencurahan perhatian, serta adanya hubungan emosi dan fisik yang akrab. Menurut Klaus, Kenell (1992), bonding attachment bersifat unik, spesifik, dan bertahan lama. Mereka juga menambahkan bahwa ikatan orang tua terhadap anaknya dapat terus berlanjut bahkan selamanya walau dipisah oleh jarak dan waktu, serta tanda-tanda keberadaan secara fisik tidak terlihat.

Yang dimaksud bounding attachment adalah sentuhan awal/kontak kulit antara ibu dan bayi pada menit-menit pertama sampai beberapa jam setelah kelahiran bayi. Bonding merupakan suatu langkah untuk mengungkapkan perasaan afeksi (kasih sayang) oleh ibu kepada bayinya segera setelah lahir, sedangkan attachment adalah interaksi antara ibu dan bayi secara spesifik mulai dari setelah kala III persalinan sampai dengan post partum sepanjang waktu

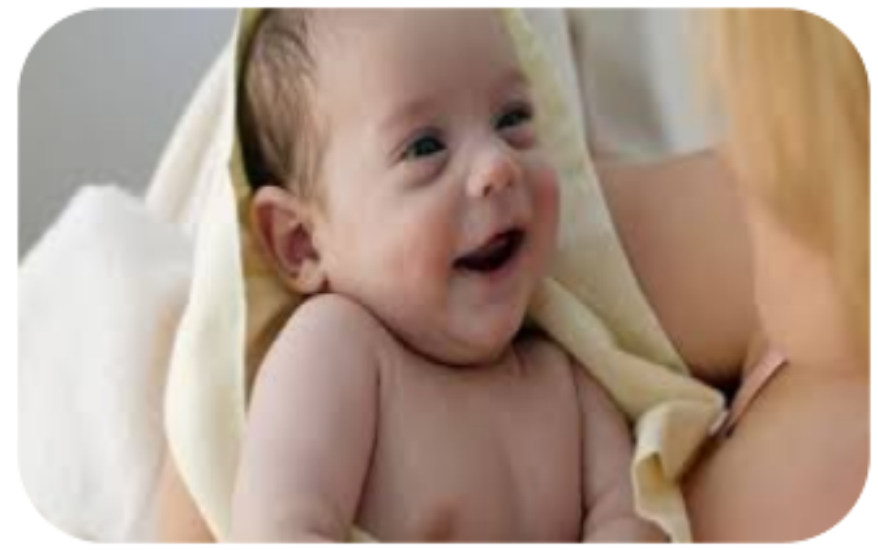

Gambar 3.1 Bonding Attachment

\section{Beberapa pemikiran dasar dari ketertarikan}

Prakondisi yang mempengaruhi ikatan (Mercer, 1996) adalah sebagai berikut:

1. Kesehatan emosional orang tua 
2. Sistem dukungan sosial yang meliputi pasangan hidup, teman, dan keluarga

3. Suatu tingkat keterampilan dalam berkomunikasi dan dalam memberi asuhan yang kompeten

4. Kedekatan orang tua dengan bayi

5. Kecocokan orang tua-bayi (termasuk keadaan, temperamen, dan jenis kelamin)

Tahap-tahap bonding attachment adalah sebagai berikut:

1. Perkenalan (acquaintance), dengan melakukan kontak mata, menyentuh, berbicara, dan mengeksplorasi segera setelah mengenal bayinya

2. Keterikatan (bounding)

3. Attachment, perasaan kasih sayang yang mengikat individu dengan individu lain

Elemen-elemen bonding attachment meliputi hal-hal sebagai berikut:

1. Sentuhan

Sentuhan atau indra peraba dipakai secara ekstensif oleh orang tua dan pengasuh lain sebagai sutu sarana untuk mengenali bayi baru lahir dengan cara mengeksplorasi tubuh bayi dengan ujung jarinya. Penelitian telah menemukan suatu pola sentuhan yang hampir sama yakin pengasuh memulai eksplorasi jari tangan ke bagian kepala dan tungkai kaki. Tidak lama kemudian pengasuh memakai telapak tangannya untuk mengelus badan bayi dan akhirnya memeluk dengan tangannya. Gerakan ini dipakai menenangkan bayi.

2. Kontak mata

Ketika bayi baru lahir mampu secara fungsional mempertahanan kontak mata, orang tua dan bayi akan menggunakan lebih banyak waktu untuk saling memandang. Beberapa ibu mengatakan, dengan melakukan kontak mata mereka merasa lebih dekat dengan bayinya. 


\section{Suara}

Saling mendengarkan dan merespon suara antara orang tua dan bayinya juga penting. Orang tua menunggu tangisan pertama bayinya dengan tegang. Bayi akan menjadi tenang dan berpaling kearah orang tua mereka saat orang tua mereka berbicara dengan suara bernada tinggi.

4. Aroma

Perilaku lain yang terjalani antara orang tua dan bayi ialah respons terhadap aroma/bau masing-masing. Ibu mengetahui setiap anak memiliki aroma yang unik. Bayi belajar dengan cepat untuk membedakan aroma susu ibunya.

5. Entrainment

Bayi baru lahir bergerak-gerak sesuai dengan struktur pembicaraan orang dewasa. Mereka menggoyang tangan, mengangkat kepala, menendang-nendangkan kaki, seperti sedang berdansa mengikuti nada suara orang tuanya. Entrainment terjadi saat anak mulai berbicara. Irama ini berfungsi memberi umpan balik positif kepada orang tua dan menegakkan suatu pola komunikasi efektif yang positif

6. Bioritme

Anak yang belum lahir atau baru lahir dapat dikatakan senada dengan ritme alamiah ibunya. Untuk itu, salah satu tugas bayi baru lahir ialah membentuk ritme personal (bioritme). Orang tua dapat membantu proses ini dengan memeberi kasih sayang yang konsisten dan dengan memanfaatkan waktu saat bayi mengembangkan perilaku yang responsive. Hal ini dapat meningkatkan interaksi sosial dan kesempatan bayi untuk belajar.

7. Kontak dini 
Saat ini, banyak bukti-bukti alamiah yang menunjukkan bahawa kontak dini setelah lahir merupakan hal yang penting dalam hubungan antara orang tua dan anak.

Menurut Klaus, Kennel (1982), ada beberapa keuntungan fisiologis yang dapat diperoleh dari kontak dini, yaitu sebagai berikut:

a. Kadar oksitosin dan prolactin meningkat

b. Reflex mengisap dilakukan secara dini

c. Pembentuk kekebalan aktif dimulai

d. Mempercepat proses ikatan antara orang tua dan anak

Dampak positif bounding attachment

a. Bayi merasa di cintai dan diperhatikan

b. Bayi akan merasa aman karena mendapat dekapan dari ibunya

c. Menumbuhkan sikap sosial

d. Merupakan langkah awal dalam menciptakan dasar-dasar kepribadian yang positif anak.

Tiga bagian dasar periode di mana ketertarikan antara ibu dan bayi berkembang adalah sebagai berikut:

1. Periode prenatal

Merupakan periode selama kehamilan. Pada masa prenatal ini wanita menerima fakta kehamilan dan mendefinisikan bayinya sebagai individu yang terpisah dari dirinya, bermimpi, dan baerfantasi tentang bayinya, serta membuat persiapan untuk bayi

Para peneliti telah memperlihatkan bahwa melodi yang menenangkan dengan ritme yang tetap, seperti musik klasik atau blues dapat membantu menenangkan kebanyakan bayi, sedangkan sebagian bersar dari mereka menjadi gelisah dan menendang-nendang jika yang 
dimainkan adalah music rock. Hal ini berarti bahwa para ibu dapat berkomunikasi dengan calon bayinya, jadi proses pembentukan ikatan batin sangat penting untuk dimulai sejak kehamilan

2. Waktu kelahiran dan sesaat setelahnya Ketika persalinan secara langsung berpengaruh terhadap proses keterkaitan ketika kelahiran bayi. Factor yang paling menonjol yang bisa memengaruhi keterikatan selama periode ini adalah pengaruh pengobatan. Proses keterikatan ini dapat terhenti apabila si ibu maupun bayi mengantuk akibat pengaruh pengobatan.

Keterkaitan pada waktu kelahiran ini dapat dimulai dengan ibu menyentuh kepala bayinya pada bagian introitus sesaat sebelum kelahiran, bahkan ketika si bayi ditempatkan di atas perut ibu sesaat setelah kelahiran. Perilaku keterikatan ini seperti penyentuhan si ibu pada bayinya ini dimulai dengan jari-jari tangan (ekstermitas) bayi lalu mengingat pada saat melingkari dada bayi dengan kedua tangannya dan berakhir ketika dia melindungi keseluruhan tubuh bayi dalam rengkuhan lengannya.

Perilaku lain dalam periode ini meliputi kontak mata dan menghabiskan waktu dalam posisi en face (tatap muka), berbicara dengan bayi, membandingkan si bayi dengan bayi yang telah diimpikannya selama kehamilan (jenis kelamin) dan menggunakan nama pada si bayi. Keterkaitan ini menyebabkan respons yang menciptakan interaksi dua arah yang menguatkan antara ibu dan bayinya. Hal ini difasilitasi karena bayi dalam fase waspada selama satu jam pertama setelah kelahiran sehingga membuat bayi reseptif terhadap rangsangan.

3. Postpartum dan pengasuhan awal 
Suatu hubungan berkembang seiring berjalannya waktu dan bergantung pada partisipasi dari ayah dan ibu untuk terlibat. Ibu mulai berperan mengasuh bayinya dengan kasih sayang. Kemampuan untuk mengasuh agar menghasilkan bayi yang sehat dapat menciptakan perasaan puas, rasa percaya diri, perasaan berkompeten, dan sukses terhadap diri ibu.

\subsection{Respons Ayah dan Keluarga}

Jika ibu sudah mengandung bayi selama sembilan bulan, ayah benar-benar merasakan kebersamaan dengan bayi saat lahir. Perkenalan ayah dengan bayi dimulai saat mereka saling bertatapan. Seperti halnya ikatan ibu dengan bayi, kedekatan ayah dengan bayi penting bagi tumbuh kembang bayi. Hasil penelitian Robert A. Veneziano dalam The Importance of Father Love menyebutkkan kedekatan ayah dan bayi sangat membantu mengembangkan kemampuan sosial, kecerdasan emosi, dan perkembangan kognitif bayi.

Ayah mungkin menjadi anggota keluarga yang terlupakan, terutama bila hal ini merupakan anak yang pertama. Sebelum bayi tiba di rumah, ia merupakan bagian terbesar dari keluarganya yang terdiri atas dua orang. Aktivitas siang hari di mana mudah disesuaikan dengan pasangannya malam hari tanpa gangguan. Kini rumah menjadi tidak terkendali, makan menjadi tidak terjadwal, tidur mengalami gangguan, dan hubungan seksual untuk sementara ditangguhkan. Ayah harus dilibatkan dalam perawatan anak dan pemeliharaan aktivitas rumah. Dengan berbagai tanggung jawab seperti ini, mereka menjadi bagian dari pengalaman mengasuh anak.

Sebagai ayah baru, peran ayah tidak kurang rumitnya dibandingkan peran istri. Sang ayah tidak mengandung si bayi 
selama 9 bulan, tetapi harus membuat penyesuainan secara fisik dan emosi ketika waktu persalinan semakin dekat dan persiapan untuk bayi menjadi penting sekali. Di satu pihak sang ayah mungkin merasa seolah-olah tidak ada hubungan dengan persalinan, tetapi pada sisi lain, ini adalah bayinya juga. Ketika bayi akhirnya lahir, sang ayah mungkin merasa sangat lega dan juga gembira, serta gugup. Sewaktu menyaksikan kelahiran bayi, perasaan komitmen dan cinta membanjir ke permukaan menghilangkan kekhawatiran bahwa sang ayah tidak akan pernah mempunyai keterikatan dengan bayinya.

Sang ayah juga merasakan penghargaan yang besar dan cinta kepada istri lebih daripada sebelumnya. Pada waktu yang sama, merenungkan tanggung jawab untuk merawat bayi ini selama 20 tahun ke depan dapat membuat sang ayah lemah. Pendekatan terbaik adalah menjadi ayah yang seaktif mungkin. Misalnya saat istrinya melahirkan di rumah sakit, ayah mungkin ditempatkan de dalam ruang rawat gabung sampai waktunya membawa pulang bayi ke rumah. Keadaan ini akan membantu ayah merasa tidak seperti penonton, tetapi lebih sebagai peserta aktif. Ayah akan mengenal bayinya dari permulaan dan memungkinkan ayah berbagi pengalaman emosional dengan istrinya.

Begitu seluruh keluarga berada di rumah, sang ayah harus dapat membantu memakaikan popok, memandikan, dan membuat bayi tenang dan nyaman. Tidak ada alas an bagi seorang ayah yang tidak mampu melaksanakan pekerjaan sehari-hari menugurus rumah dan anak sebaik ibu. Umumnya ayah yang bersedia mengurus rumah tangga hanya untuk menyenangkan istrinya saja. Alangkah baiknya jika pekerjaan ini dikerjakan dengan perasaan bahwa sudah selayaknya menerima tanggung jawab di dalam rumah yaitu merawat anak dan rumah tangga sehari-hari. 
Ada ayah yang cepat mendapatkan ikatan kuat dengan bayinya, ada pula yang membutuhkan waktu agak lama. Ada beberapa faktor yang ikut mempengaruhi terciptanya bonding. Salah satunya keterlibatan ayah saat bayi dalam kandungan. Semakin terlibat ayah, semakin mudah ikatan terbentuk.

Hasil penelitian menunjukkan $62 \%$ ayah mengalami depresi pasca lahir atau baby blues. Perasaan cemas, khawatir, dan takut dapat muncul saat seorang pria menyadari dirinya kini memiliki peran baru yaitu sebagai ayah

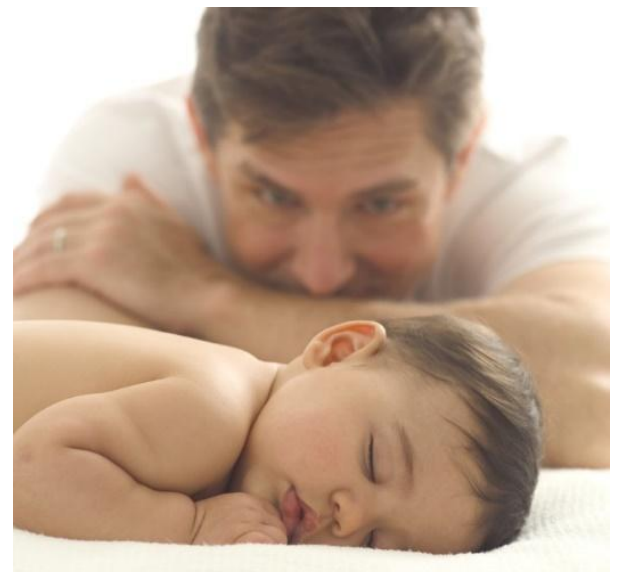

Gambar 3.2 Respons ayah terhadap kelahiran bayi

Perasaan cemburu inipun dapat timbul terhadap sang ayah. Kadang-kadang para ayah menjadi cemburu terhadap hubungan antara ibu/ istrinya dengan anak-anak mereka sendiri, bayi adalah produk dari hubungan mereka dan semestinya memperkaya hubungan itu. Meskipun demikian kadang para ayah merasa ditinggalkan terutama bila ibu dan bayi adalah pusat perhatian dalam keluarga, sehingga muncullah perasaan "disingkirkan" pada diri sang ayah. 
Untuk mencegah kecemburuan sang ayah ini agar diupayakan keterlibatan ayah dalam merawat bayi karena merawat dan mengasuh bayi dewasa ini bukan hanya tugas seorang ibu, ayah diupayakan sebanyak mungkin terlibat dalam proses mengasuh bayi seperti memberi makan, mengganti popok, menidurkan bayi dll

Respons keluarga seperti kakek atau nenek akan merasakan kepuasan besar karena melihat satu generasi baru dalam keluarganya dan bahagia karena cucunya akan mengetahui warisan dan tradisi mereka. Dengan adanya anggota keluarga lain seperti kakek, nenek, dan para sepupu akan memberikan kesempatan yang ideal bagi bayi untuk membentuk lebih dari satu ikatan dan masing-masing ikatan akan mempunyai nilai sendiri. Perilaku orang tua yang dapat mempengaruhi ikatan kasih sayang :

1) Perilaku memfasilitasi

a. Memandangi anak, serta mencari ciri khas anak

b. Kontak mata

c. Memberikan sebuah perhatian terhadap kebutuhan anak

d. Menganggap anak sebagai individu yang unik

e. Menganggap anak sebagai anggota keluarga

f. Memberikan senyuman

g. Berbicara atau berinteraksi dengan anak

h. Menunjukkan kegembiraan dan kebanggaan terhadap anak

i. Mengajak anak pada acara keluarga

j. Memahami prilaku anak serta memenuhi kebutuhan anak

k. Bereaksi positif terhadap prilaku anak.

2) Perilaku menghambat 
a. Menjauh dari anak, tidak memperdulikan kehadirannya, serta menghindar dan menolak untuk menyentuh anak.

b. Tidak menganggap anak sebagai anggota keluarga, tidak memperdulikan keberadannya, tidak memberikan nama pada anak.

c. Membenci anak, menganggap sesuai yang tidak menyenangkan

d. Tidak mau menyentuh anaknya.

e. Tidak mau menyusuinya

f. Kecewa dengan anak, dan tidak memperdulikannya dengan tidak memenuhi kebutuhannya.

Perilaku orang tua serta keluarga terhadap bayi baru lahir sebagian dipengaruhi oleh factor eksternal dan internal.

\section{Faktor Internal}

1. Bagaimana mereka diurus oleh orang tua mereka. Bila si ayah atau individu lain pada waktu kecil dididik orang tua dengan keras atau sering diberikan hukuman apabila ada kesalahan sedikit, maka kemungkinan kedekatan antara ayah dan bayi akan sulit terbentuk dan cara ini akan diterapkan untuk mendidik anaknya kelak

2. Kebudayaan yang diinternalisasikan dalam diri mereka. Sebagaian besar masyarakat masih terdapat kepercayaan bahwa ibu dan bayi yang baru lahir tidaklah bersih, dan harus diisolasi dari ayahnya selama periode yang ditetapkan. Hal ini tentu saja menyulitkan terbentuknya ikatan batin bayi dengan sang ayah

3. Nilai-nilai kehidupan, kepercayaan dan nilai-nilai dalam kehidupan memengaruhi perilaku dan respons seseorang. Dalam agama islam, bayi yang baru lahir sesegera mungkin di adzankan oleh sang ayah, keadaan ini memberikan kesempatan ayah untuk mencoba 
menggendong bayi pertama kalinya dan bayi mendengarkan suara sang ayah

4. Hubungan antar sesama akan menciptakan suatu pengalaman, seperti bila sang ayah melihat atau mendengar cerita dari temannya bagaimana temannya bersikap terhadap anak pertamanya. Bila sang ayah mempunyai hubungan dalam lingkungannya harmonis, mudah bersosialisasi, maka akan menciptakan respons yang positif terhadap bayinya

5. Riwayat kehamilan sebelumnya. Apabila pada kehamilan terdahulu ibu mengalami komplikasi dalam kehamilan seperti abortus, plasenta previa, dan lain-lain, akan membuat ayah/ibu maupun keluarga sangat menjaga dan melindungi bayi dengan sebaiknya

\section{Factor Eksternal}

1. Keinginan menjadi orang tua yang telah diimpikan. Pasangan suami istri yang sangat menginginkan anak tentu saja akan merespons kelahiran bayi dengan bangga dan bahagia. Perhatian yang diterima selama kehamilan, persalinan, dan postpartum; perhatian dari suami dan keluarga akan menciptakan perasaan kebahagiaan dan bangga akan perannya sebagai seorang ibu setelah persalinan

2. Sikap dan perilaku pengunjung. Pengunjung memberikan pujian dan ucapan selamat, serta memperlihatkan perasaan bangga terhadap si bayi, hal ini akan menumbuhkan perasaan bahagia akan kehadiran bayi

\subsection{Sibling Rivalry}

Salah satu peristiwa kunci dalam kehidupan seorang anak adalah kelahiran adik baru. Kehamilan itu sendiri merupakan waktu ideal bagi anak-anak untuk memahami dari 
mana bayi berasal dan bagaimana bayi itu dilahirkan. Anak mungkin memiliki reaksi campuran terhadap adik baru, bergairah karena mendapat teman bermain baru, takut akan ditelantarkan, dan sering kecewa ketika sang adik tidak mau segera bermain.

Akan tetapi persaingan sengit yang ditakutkan oleh banyak orang tua bukan tidak dapat dihindari. Temperamen anak tertentu dan cara orang tua memperlakukan anak adalah factor kunci yang menentukan seberapa besar persaingan yang terjadi di antara saudara kandung. Tidak mudah memang untuk menjaga keseimbangan yang tepat antara menyesuaikan diri dengan kebutuhan bayi baru dan membantu anak yang lebih besar mengatasi perubahan itu. Usahakan agar anak yang lebih besar mendapat beberapa keistimewaan, mungkin dengan waktu tidur lebih larut atau waktu khusus untuk perhatian yang tidak terbagi untuknya. Pastikan pula bahwa anak yang lebih kecil dilindungi dari perlakuan marah dan suka memerintah dari anak yang lebih besar, lebih kuat, dan lebih pandai.

Percekcokan yang bercampur dengan permainan yang menyenangkan adalah pola yang lazim di antara kakak dan adik. Tidak bijaksana bila kita mengharapkan seorang anak selalu bertindak adil menurut standar orang dewasa. Sebaiknya bertindak tegas terhadap semua anak saat bertengkar atau memarahi mereka semua ketika mereka berkelahi daripada mencoba menyelidiki siapa yang benar dan siapa yang salah. Walaupun tanpa bisa dihindari sekali waktu mungkin bertindak berlebihan, waspadalah agar seorang anak jangan selalu diberi dukungan dengan mengorbankan anak lain.

Factor penyebeb terjadinya sibling rival yakni :

a. Anak-anak merasa hubungan dengan orang tua mereka terancam oleh kedatangan anggota keluarga baru. 
b. Kasih sayang orang tua yang terbagi sehingga membuat masing-masing anak bersaing untuk mendapatkan perhatian lebih dari orang yua.

c. Kecenderungan orang tua terhadap salah satu anak, sehingga membuat anak yang lain merasa kurang mendapatkan perhatian dari orang tua mereka

d. Orang tua memuji kelebihan anak yang lain dihadapan anak yang memiliki kekurangan

e. Adanya konflik dan ketidaksetujuan hidup bersama dengan orang lain dalam jangka waktu yang cukup lama.

f. Kemampuan masing-masing anak yang berbeda dengan usia yang tidak jauh berbeda dan jenis kelaminnya sama.

Bentuk perilaku sibling rival :

a. Bersifat langsung yang dimunculkan dalam bentuk perilaku agresif mengarah ke fisik, seperti menggigit, memukul, mencakar, melukai dan menendang atau usaha yang dapat diterima secara sosial untuk mengalahkan saingannya.

b. Reaksi lain dapat muncul secara tidak langsung bersifat lebih halus sehingga sulit untuk dikenali, seperti : mengompol, pura-pura sakit, menangis, dan menjadi nakal.

Jika saudara kandung adalah anak prasekolah, dia akan dapat lebih memahami apa yang sedang terjadi. Dengan mempersiapkan selama kehamilan, orang tua dapat membantu mengurangi kebingungan atau rasa irinya. Dia dapat memahami fakta dasar dari situasi tersebut dan dia kemungkinan akan sangat ingin tahu tentang orang yang dia ketahui ini. Begitu bayi lahir, anak yang lebih besar merasa kehilangan orang tuanya dan marah karena bayi akan menjadi pusat perhatian baru. Akan tetapi dengan memuji dia karena telah membantu dan bertindak seperti "orang dewasa" akan membuat anak 
tahu bahwa dia juga mempunyai peran baru yang penting untuk dimainkan. Pastikan bahwa anak mendapatkan waktu menjadi "orang penting" dan diizinkan menjadi "bayi" sewaktu dia merasa perlu. Selain itu sering diberikan kesempatan agar dia tahu bahwa ada cukup ruang dan cinta kasih dalam hati orang tua untuk mereka berdua.

Jika saudara kandung sudah memasuki usia sekolah, dia mungkin tidak lagi merasa terancam oleh pendatang baru dalam keluarga. Bahkan kemungkinan besar dia kagum dengan proses kehamilan dan persalinan, serta ingin sekali bertemu dengan bayi yang baru.

Hal terpenting untuk meminimalkan masalah yang akan datang anak perlu dipersiapkan untuk menerima saudaranya yang baru lahir dimulai sejak masa kehamilan. Hal ini menunjukkan bahwa anak yang lebih tua masih mendapatkan kasih sayang walaupun hadir adiknya nanti.

Dampak terjadinya sibling rival yakni :

a. Pertengkaran yang terus menerus di pupuk sejak kecil dan akan terus meruncing saat anak-anak beranjak dewasa.

b. Mereka akan selamanya terus bersaing dan saling membenci, mendengki satu sama lain.

c. Dengan adanya persaingan dalam diri anak, akan tertanam asumsi bahwa saudara kandung adalah saingannya, dan anak merasa tersaingi sehingga membuat asumsi bahwa anak harus menjadi anak paling baik diantara saudara kandungnya dengan segala cara.

d. Dampak paling fatal dari sibling rival yakni, putusnya tali persaudaraan jika orang tua mereka telah meninggal.

Beberapa hal yang dapat dilakukan untuk mengurangi frekuensi maupun intensitas sibling rival : 
a. Infomasikan kepada anak dengan mempekenalkan kakaknya kepada bayi didalam kandungan, libatkan dia dalam kehamilan seperti : mengantar ke dokter

b. Libatkan anak dalam mempersiapkan kelahiran adiknya seperti : belanja baju bayi.

c. Berikan anak perhatian dan cinta yang khusus.

d. Jangan membanding-banding anak

e. Jangan jadikan sebagai pengasuh adiknya

f. Buatlah pembagian tugas rumah masing-masing anak.

g. Kembangkan dan ajarkan anak bersikap empati dan memperhatikan saudaranya yang lain

h. Perluas lingkup sosial anak pertama

i. Jujurlah soal perubahan fisik dan mental seperti gampang lelah, disertai minta maaf karena tidak bisa menggendongnya sesuka hati

j. Dihari-hari pertama kelahiran bayi bersikaplah sewajarnya seperti biasanya dan libatkan ia dalam menyambu tamu dan tugas- tugas ringan perawatan bayi

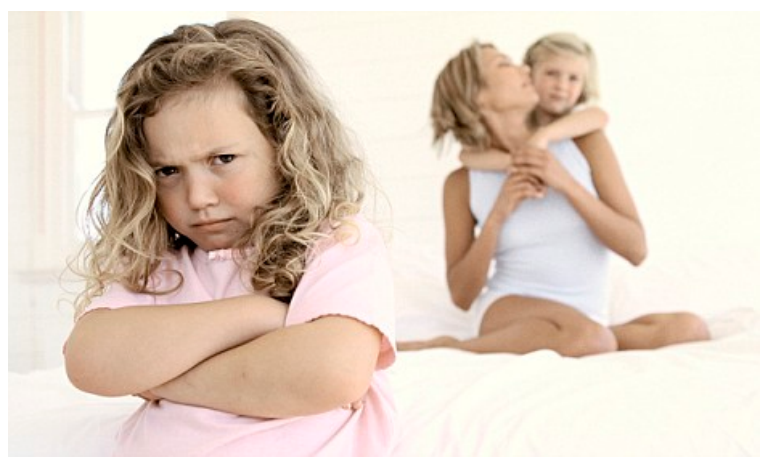

Gambar 3.3 Sibling Rivalry

Sisi Positif Sibling Rivalry, Meskipun sibling rivalry mempunyai pengertian yang negatif tetapi ada segi positifnya, antara lain : 
a. Mendorong anak untuk mengatasi perbedaan dengan mengembangkan beberapa keterampilan penting.

b. Cara cepat untuk berkompromi dan bernegosiasi.

c. Mengontrol dorongan untuk bertindak agresif.

Oleh karena itu agar segi positif tersebut dapat dicapai, maka orang tua harus menjadi fasilitator. Mengatasi Sibling Rivalry, Beberapa hal yang perlu diperhatikan orang tua untuk mengatasi sibling rivalry, sehingga anak dapat bergaul dengan baik, antara lain:

a. Tidak membandingkan antara anak satu sama lain.

b. Membiarkan anak menjadi diri pribadi mereka sendiri.

c. Menyukai bakat dan keberhasilan anak-anak Anda.

d. Membuat anak-anak mampu bekerja sama daripada bersaing antara satu sama lain.

e. Memberikan perhatian setiap waktu atau pola lain ketika konflik biasa terjadi.

f. Mengajarkan anak-anak Anda cara-cara positif untuk mendapatkan perhatian dari satu sama lain.

g. Bersikap adil sangat penting, tetapi disesuaikan dengan kebutuhan anak. Sehingga adil bagi anak satu dengan yang lain berbeda.

h. Merencanakan kegiatan keluarga yang menyenangkan bagi semua orang.

i. Meyakinkan setiap anak mendapatkan waktu yang cukup dan kebebasan mereka sendiri.

j. Orang tua tidak perlu langsung campur tangan kecuali saat tanda-tanda akan kekerasan fisik.

k. Orang tua harus dapat berperan memberikan otoritas kepada anak-anak, bukan untuk anak-anak. 
I. Orang tua dalam memisahkan anak-anak dari konflik tidak menyalahkan satu sama lain.

m. Jangan memberi tuduhan tertentu tentang negatifnya sifat anak.

n. Kesabaran dan keuletan serta contoh-contoh yang baik dari perilaku orang tua sehari-hari adalah cara pendidikan anak-anak untuk menghindari sibling rivalry yang paling bagus. 


\section{BAB 5 : Kebutuhan Dasar Masa Nifas}

Periode postpartum adalah waktu penyembuhan dan perubahan yaitu waktu kembali pada sebagaimana keadaan tidak hamil. Dalam masa nifas, alat-alat genetalia interna maupun eksterna akan berangsur-angsur pulih seperti pada keadaan sebelum hamil. Untuk membantu mempercepat proses penyembuhan pada masa nifas, maka ibu nifas membutuhkan diet yang cukup kalori dan protein, membutuhkan istirahat yang cukup dan sebagainya. Kebutuhan-kebutuhan yang dibutuhkan ibu nifas antara lain sebagai berikut:

1) Nutrisi dan cairan

2) Ambulasi

3) Eliminasi bak/bab

4) Kebersihan diri/perineum

5) Istirahat

6) Seksual

7) Keluarga berencana

8) Latihan/senam nifas

\subsection{Nutrisi dan Cairan}

Ibu nifas membutuhkan nutrisi yang cukup, gizi seimbang, terutama kebutuhan protein dan karbohidrat. Gizi pada ibu menyusui sangat erat kaitannya dengan produksi ASI, dimana ASI sangat dibutuhkan untuk tumbuh kembang bayi. Nutrisi ibu menyusui tidaklah rumit, yang terpenting adalah makanan yang dapat memenuhi kebutuhan nutrisi ibu nifas, serta menjamin pembentukan air susu yang berkualitas dalam jumlah yang cukup untuk memenuhi kebutuhan bayinya.

Kualitas dan jumlah makanan yang dikonsumsi ibu nifas sangat mempengaruhi produksi ASI. Ibu nifas harus mendapatkan zat 
makanan sebesar 800 kkal yang digunakan untuk produksi ASI dan untuk proses kesembuhan ibu. Pemberian ASI sangat penting karena ASI merupakan makanan utama bagi bayi. Dengan ASI, bayi akan tumbuh dengan baik sebagai manusia yang sehat, bersifat lemah lembut, dan mempunyai IQ yang tinggi. Hal ini disebabkan karena ASI mengandung asam dekosa heksanoid (DHA). Bayi yang diberi ASI secara bermakna akan mempunyai IQ yang lebih tinggi dibandingkan dengan bayi yang hanya diberi susu formula.

Selama menyusui, jika ibu dengan status gizi yang baik rata-rata memproduksi ASI sekitar 800cc yang mengandung sekitar 600 kkal, sedangkan pada ibu dengan status gizi kurang biasanya memproduksi ASI kurang. Walaupun demikian, status gizi tidak berpengaruh besar terhadap mutu ASI, kecuali volumenya.

1. Kebutuhan kalori selama menyusui proporsional dengan jumlah air susu ibu yang dihasilkan dan lebih tinggi selama menyusui disbanding selama hamil. Rata-rata kandungan kalori ASI yang dihasilkan ibu dengan nutrisi baik adalah $70 \mathrm{kal} / 100 \mathrm{ml}$ dan kira-kira 85 kal diperlukan oleh ibu untuk tiap $100 \mathrm{ml}$ yang dihasilkan. Rata-rata ibu menggunakan 640 kal/hari untuk 6 bulan pertama dan $510 \mathrm{kal} / \mathrm{hari}$ selama 6 bulan kedua untuk menghasilkan jumlah susu normal. Rata-rata ibu harus mengonsumsi 2.300-2.700 kal ketika menyusui. Makanan yang dikonsumsi ibu berguna untuk melakukan aktivitas, metabolisme, cadangan dalam tubuh, proses produksi ASI, serta sebagai ASI itu sendiri yang akan dikonsumsi bayi untuk pertumbuhan dan perkembangan bayi. Makanan yang dikonsumsi juga perlu memenuhi syarat, seperti: susunannya harus seimbang, porsinya cukup dan teratur, tidak terlalu asin, pedas atau berlemak, serta tidak mengandung alkohol, nikotin, bahan pengawet, dan pewarna. 
2. Ibu memerlukan tambahan $20 \mathrm{gr} /$ hari protein di atas kebutuhan normal ketika menyusui. Dasar kebutuhan ini adalah tiap 100cc ASI mengandung 1,2 gram protein. Dengan demikian, 830 cc ASI mengandung 10 gram protein. Efisiensi konversi protein makanan menjadi protein susu hanya $70 \%$ (dengan variasi perorangan). Peningkatan kebutuhan ini ditujukan bukan hanya untuk transformasi menjadi protein susu, tetapi juga untuk sintesis hormone yang memproduksi (prolaktin), serta yang mengeluarkan ASI (oksitosin).

Protein diperlukan untuk pertumbuhan dan penggantian sel-sel yang rusak atau mati. Sumber protein dapat diperoleh dari protein hewani dan nabati. Protein hewani antara lain telur, daging, ikan, udang, kerang, susu, dan keju. Sementara itu, protein nabati banyak terkandung dalam tahu, tempe, kacang-kacangan, dan lain-lain.

Ibu nifas juga dianjurkan untuk mendapatkan asupan dari nutrisi lain, berikut adalah perbandingan tambahan nutrisi ibu menyusui pada wanita asia dan amerika

Table 5.1 Perbandingan tambahan nutrisi ibu menyusui untuk wanita asia dan amerika

\begin{tabular}{cccc}
\hline NO & Nutrisi & Wanita Asia & Wanita Amerika \\
\hline 1 & Kalsium & $0,5-1 \mathrm{gram}$ & 400 gram \\
\hline 2 & Zat Besi & $20 \mathrm{mg}$ & $30-60 \mathrm{mg}$ \\
\hline 3 & Vitamin C & $100 \mathrm{mg}$ & $40 \mathrm{mg}$ \\
\hline 4 & Vitamin B1 & $1,3 \mathrm{mg}$ & $0,5 \mathrm{mg}$ \\
\hline 5 & Vitamin B2 & $1,3 \mathrm{mg}$ & $0,5 \mathrm{mg}$ \\
\hline 6 & Vitamin B12 & 2,6 mikrogram & 1 mikrogram \\
\hline 7 & Vitamin D & 10 mikrogram & 5 mikrogram \\
\hline
\end{tabular}

Selain nutrisi tersebut, ibu menyusui juga dianjurkan makan makanan yang mengandung asam lemak Omega 3 yang banyak 
terdapat dalam ikan kakap, tongkol, dan lemuru. Asam ini akan diubah menjadi DHA yang akan dikeluarkan melalui ASI. Kalsium terdapat pada susu, keju, teri, kacang-kacangan . zat besi banyak terdapat pada makanan laut. Vitamin C banyak terdapat pada buah buahan yang memiliki rasa asam, seperti jeruk, manga, sirsak, apel, tomat dll. Vitamin B1 dan B2 terdapat pada kacang-kacangan, hati, telur, ikan, dan sebagainya. Ada beberapa sayuran yang menurut pengalaman masyarakat dapat memperbanyak pengeluaran ASI, misalnya sayur daun turi (daun katuk) dan kacang-kacangan.

Kesimpulan dari beberapa anjuran yang berhubungan dengan pemenuhan gizi ibu menyusui antara lain :

1) Mengkonsumsi tambahan kalori setiap hari sebanyak 500 kalori

2) Makan dengan diet seimbang, cukup protein, mineral, dan vitamin.

3) Minum sedikitnya 3 liter setiap hari, terutama setelah menyusui.

4) Mengkonsumsi tablet zat besi selama masa nifas.

5) Minum kapsul vitamin A (200.000 unit).

Kekurangan gizi pada ibu menyusui dapat menimbulkan gangguan kesehatan pada ibu dan bayinya. Gangguan pada bayi meliputi proses tumbuh kembang anak, bayi mudah sakit, dan mudah terkena infeksi. Kekurangan zat-zat esensial menimbulkan gangguan pada mata maupun tulang

\subsection{Ambulasi Dini (Early Ambulation)}

Pada masa lampau, perawatan puerperium sangat konservatif, di mana puerperal harus tidur terlentang selama 40 hari. Kini 
perawatan puerperium lebih aktif dengan dianjurkan untuk melakukan mobilisasi dini.

Ambulasi dini adalah latihan aktifitas ringan membimbing ibu untuk segera pulih dari trauma persalinan, dengan cara membimbing ibu mulai dari miring kanan miring kiri, latihan duduk, berdiri bangun dari tempat tidur, kemudian dilanjutkan latihan berjalan. Menurut penelitian ambulasi dini tidak mempunyai pengaruh buruk bagi ibu post partum, perdarahan abnormal, luka episiotomy, dan tidak menyebabkan terjadinya prolapse uteri atau terjadinya retrofleksi. Ambulasi dini sangat bermanfaat bagi ibu nifas dengan kondisi normal namun tidak buat ibu nifas dengan penyakit anemia, jantung, paru-paru, demam, dan keadaan lain yang masih membutuhkan istirahat.

Perawatan mobilisasi dini mempunyai keuntungan, yaitu:

1. Melancarkan pengeluaran lokia, mengurangi infeksi puerperium

2. Mempercepat involusi uterus

3. Melancarkan fungsi alat gastrointestinal dan alat kelamin

4. Meningkatkan kelancaran peredaran darah sehingga mempercepat fungsi ASI dan pengeluaran sisa metabolisme Ambulasi dini merupakan usaha untuk memulihkan kondisi ibu nifas secepat mungkin mungkin untuk berjalan. Pada persalinan normal sebaiknya ambulasi dikerjakan setelah 2 jam (ibu boleh miring ke kiri atau ke kanan untuk mencegah adanya trombosit)

Keuntungan lain dari ambulasi dini adalah sebagai berikut

1. Ibu merasa lebih sehat dan kuat

2. Faal usus dan kandung kemih menjadi lebih baik

3. Kesempatan yang baik untuk mengajar ibu merawat/memelihara anaknya

4. Tidak menyebabkan perdarahan abnormal 
5. Tidak memengaruhi penyembuhan luka episiotomy atau luka di perut

6. Tidak memperbesar kemungkinan prolapse atau retoflexio

Ambulasi dini dilakukan dengan melakukan gerakan dan jalan-jalan ringan sambil bidan melakukan observasi perkembangan pasien dari hitungan jam hingga hari. Kegiatan ini dilakukan secara meningkat berangsur-angsur frekuensi dan intensitas aktivitasnya sampai pasien dapat melakukannya sendiri tanpa pendampingan, untuk tercapainaya tujuan membuat pasien dapat beraktifitas secara mandiri.

\subsection{Eliminasi : Buang Air Kecil dan Besar (BAB dan BAK)}

Dalam 6 jam post partum, pasien sudah harus dapat buang air kecil. Semakin lama urine tertahan dalam kandung kemih maka dapat mengakibatkan kesulitan pada organ perkemihan, misalnya infeksi. Biasanya, pasien menahan air kencing karena takut akan merasakan sakit pada luka jalan lahir. Bidan harus dapat meyakinkan pada pasien bahwa kencing segera setelah persalinan dapat mengurangi komplikasi post partum. Berikan dukungan mental pada pasien bahwa ibu pasti mampu menahan sakit pada luka jalan lahir akibat terkena air kencing, karena ibupun telah berhasil berjuang untuk melahirkan bayinya.

BAK normal dalam tiap 3-4 jam secara spontan. Bila tidak mampu BAK sendiri, maka dilakukan tindakan bleder training, berikut ini:

1. Dirangsang dengan mengalirkan air keran di dekat klien

2. Mengompres air hangat di atas simfisis

3. Saat site bath (berendam air hangat) klien disuruh BAK 
Bila tidak berhasil dengan cara diatas, maka dilakukan kateterisasi. Hal ini dapat membuat klien merasa tidak nyaman dan risiko infeksi saluran kemih tinggi. Oleh karena itu kateterisasi tidak dilakukan sebelum lewat enam jam postpartum.

Dalam 24 jam pertama, ibu post partum harus dapat buang air besar, karena semakin lama feses tertahan dalam usus makan akan mengeras karena ciran yang terkandung dalam feses akan terserap oleh usus. Bidan harus dapat meyakinkan pasien agar tidak takut buang air besar, karena tidak akan mempengaruhi luka jalan lahir. Untuk meningkatkan volume feses, anjurkan pasien untuk makan tinggi serat dan banyak minum air putih.

Buang air besar (BAB). Defekasi (buang air besar) harus ada dalam 3 hari postpartum. Bila ada obstipasi dan timbul koprostase hingga skibala (feses yang mengeras) tertimbun di rectum, mungkin akan terjadi febris. Bila terjadi hal demikian dapat dilakukan klisma atau diberi laksan per os (melalui mulut).

Pengeluaran cairan lebih banyak pada waktu persalinan sehingga dapat mempengaruhi terjadinya konstipasi. Biasanya bila penderita tidak BAB sampai 2 hari sesudah persalinan, akan ditolong dengan pemberian spuit gliserine/diberikan obat-obatan. Jika dalam 2-3 hari postpartum masih susah BAB, maka sebaiknya diberikan laksan atau paraffin (1-2 hari postpartum), atau pada hari ke-3 diberi laksa supositoria dan minum air hangat. Berikut adalah cara agar dapat $B A B$ dengan teratur:

1. Diet teratur

2. Pemberian cairan yang banyak

3. Ambulasi yang baik 
4. Bila takut BAB secara episiotomy, maka diberikan laksan suposotria

\subsection{Personal Hygiene dan Perineum}

Mandi di tempat tidur dilakukan sampai ibu dapat mandi sendiri di kamar mandi. Bagian yang paling utama dibersihkan adalah puting susu dan mamae

a. Puting susu

Harus diperhatikan kebersihannya dan luka pecah (rhagade) harus segera diobati karena kerusakan puting susu merupakan port de entrée dan dapat menimbulkan mastitis. Air susu yang menjadi kering akan menjadi kerak dan dapat merangsang kulit sehingga timbul enzema. Oleh karena itu, sebaiknya puting susu dibersihkan dengan air yang telah dimasak, tiap kali sebelum dan sesudah menyusukan bayi, diobati dengan salep penisilin, lanolin, dan sebagainya.

b. Partum lokia

Lokia adalah cairan yang keluar dari vagina pada masa nifas yang berupa sekret dari rahim terutama luka plasenta. Pada 2 hari pertama, lokia berupa darah disebut lokia rubra. Setelah 3-7 hari merupakan darah encer disebut lokia serosa. Dan pada hari ke-10 menjadi cairan putih atau kekuning-kuningan yang disebut lokia alba.

Lokia berbau amis dan lokia yang berbau busuk menandakan adanya tanda infeksi. Jika lokia berwarna merah setelah 2 minggu ada kemungkinan tertinggalnya sisa plasenta atau karena involusi yang kurang sempurna yang sering disebabkan 
karena retrolexio uteri. Tanda-tanda pengeluaran lokia yang menunjukkan keadaan yang abnormal adalah sebagai berikut:

1. Perdarahan yang berkepanjangan

2. Pengeluaran lokia tertahan

3. Rasa nyeri yang berlebihan

4. Terdapat sisa plasenta yang merupakan sumber perdarahan

5. Terjadi infeksi intra uteri

Keadaan patologis (abnormal) memerlukan penanganan sebagai berikut:

1. Kebersihan lingkungan perlu diperhatikan

2. Tempat tidur perlu dijaga kebersihannya, WC/ kloset harus diperhatikan untuk menghindari terjadinya error infeksi

3. Error infeksi ini juga dapat terjadi: perawat tidak mencuci tangan sebelum dan sesudah memberikan tindakan, perawat sedang sakit misalnya batuk, pilek atau sakit kulit, kebersihan alat keperawatan yang digunakan harus asepsis dan anuseptis

\section{Perineum}

Bila sudah $B A B$ atau BAK perineum harus dibersihkan secara rutin. Caranya dibersihkan dengan sabun yang lembut minimal sehari sekali. Biasanya ibu akan takut jahitannya lepas, juga merasa sakit sehingga perineum tidak dibersihkan atau tidak dicuci. Cairan sabun yang hangat atau sejenisnya sebaiknya dipakai setelah ibu BAK atau BAB. Sesudah atau sebelum mengganti pembalut (pad) harus cuci tangan dengan menggunakan desinfektan atau sabun. Ibu perlu diberitahu cara mengganti pembalut yaitu bagian dalam jangan sampai terkontaminasi oleh tangan. Cara memakaikannya adalah dari depan ke belakang. Langkah-langkah penanganan kebersihan diri adalah sebagai berikut: 
1. Anjurkan kebersihan seluruh tubuh untuk mencegah infeksi dan alergi kulit pada bayi. Kulit ibu yang kotor karena keringat dan debu dapat menyababkan kulit bayi mengalami alergi melalai sentuhan kulit ibu dengan bayi.

2. Ajarkan ibu bagaimana membersihkan daerah kelamin dengan sabun dan air. Pastikan bahwa ibu mengerti untuk membersihkan daerah sekitar vulva terlebih dahulu dari depan ke belakang, baru kemudian dibersihkan daerah sekitar anus. Nasihatilah kepada ibu untuk membersihkan vulva setiap kali setelah BAB atau BAK

3. Sarankan ibu untuk mengganti pembalut atau kain setidaknya 2 kali sehari, kain dapat digunakan ulang jika telah dicuci dengan baik dan dikeringkan di bawah matahari atau disetrika

4. Sarankan ibu untuk mencuci tangan dengan sabun dan air, sebelum dan sesudah membersihkan daerah kelaminnya

5. Jika ibu memiliki luka episiotomy atau laserasi, sarankan kepada ibu untuk menghindari dan menyentuh luka

Beberapa langkah untuk menjaga kebersihan bayi adalah sebagai berikut:

1. Memandikan bayi

Tujuan dari memandikan bayi adalah untuk menjaga kebersihan, memberikan rasa segar, memberikan rangsangan pada kulit. Hal-hal yang harus diperhatikan saat memandikan bayi adalah sebagai berikut:

a. Mencegah kedinginan

b. Mencegah masuknya air ke dalam mulut, hidung, dan telinga

c. Memperhatikan adanya lecet pada pantat, lipatan-lipatan kulit (ketiak bayi, lipatan paha, dan punggung bayi) 


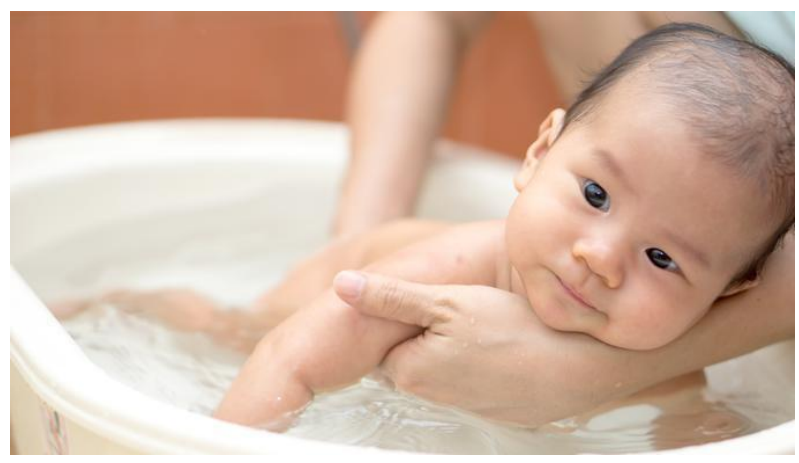

Gambar 5.1 memandikan bayi

2. Memberikan pakaian pada bayi

Bahan pakaian yang akan dikenakan oleh bayi hendaknya yang lembut dan mudah menyerap keringat

3. Personal hygiene pada bayi

Setiap kali BAK dan BAB bersihkan daerah perinealnya dengan air dan sabun, serta keringkan dengan baik. Kotoran bayi dapat menyebabkan infeksi sehingga harus segera dibersihkan

\subsection{Istirahat}

Umumnya wanita sangat lelah setelah melahirkan, akan terasa lebih lelah bila proses persalinan berlangsung lama. Seorang ibu baru akan merasa cemas apakah ia mampu merawat anaknya atau tidak setelah melahirkan. Hal ini menyebabkan susah tidur, alasan lainnya adalah terjadi gangguan pola tidur karena beban kerja bertambah, ibu harus bangun malam untuk meneteki, untuk mengganti popok yang sebelumnya tidak pernah dilakukan. Berikut adalah hal-hal yang dapat dianjurkan pada ibu:

1. Beristirahat yang cukup untuk mencegah kelelahan yang berlebihan

2. Sarankan ia untuk kembali ke kegiatan yang tidak berat 
Ibu post partum sangat membutuhkan istirahat yang berkualitas untuk memulihkan kembali keadaan fisiknya. Keluarga disarankan untuk memberikan kesempatan kepada ibu untuk beristirahat yang cukup sebagai persiapan untuk energy menyusui bayinya nanti.

Kurang istirahat akan mempengaruhi ibu post partum dalam beberapa hal diantaranya adalah sebagai berikut:

1. Mengurangi jumlah produksi ASI.

2. Memperlambat proses involusi uterus, sehingga beresiko memperrbanyak pendarahan

3. Menyebabkan depresi dan ketidakmampuan untuk merawat bayi dan dirinya sendiri

Bidan harus menyampaikan kepada pasien dan keluarga bahwa untuk kembali melakukan kegiatan-kegiatan rumah tangga, harus dilakukan secara bertahap. Selain itu mengajurkan pada ibu post partum untuk istirahat selagi bayi tidur. Kebutuhan istirahat ibu minimal 8 jam sehari, yang dapat di penuhi melalui istirahat siang dan malam.

\subsection{Seksual}

Dinding vagina akan kembali ke keadaan seperti sebelum hamil dalam waktu 6-8 minggu. Secara fisik, aman untuk memulai hubungan suami istri setelah berhentinya perdarahan, dan ibu dapat mengecek dengan menggunakan jari kelingking yang dimasukkan ke dalam vagina. Begitu darah merah berhenti dan ibu merasa tidak ada gangguan, maka aman untuk memulai melakukan hubungan suami istri di saat ibu merasa siap.

Banyak budaya yang mempunyai tradisi memulai hubungan suami istri sampai masa waktu tertentu, misalnya setelah 40 hari atau 60 hari setelah persalinan. Hubungan seksual dapat dilakukan dengan aman ketika luka episiotomy telah sembuh dan lokia telah 
berhenti. Sebaliknya hubungan seksual dapat ditunda sedapat mungkin sampai 40 hari setelah persalinan karena pada saat itu diharapkan organ-organ tubuh telah pulih kembali

\subsection{Keluarga berencana}

Menurut WHO, jarak kehamilan sebaiknya 24 bulan atau 2 tahun. Ibu post partum dan keluarga juga harus memikirkan tentang menggunakan alat kontrasepsi setelah persalinan untuk menghindari kehamilan yang tidak direncanakan. Penggunaan alat kontrasepsi setelah persalinan dapat melindungi ibu dari resiko kehamilan, karena menjalani proses kehamilan seorang wanita membutuhkan fisik dan mental yang sehat serta stamina yang kuat. Untuk mengatur jarak kehamilan ibu dapat menggunaan alat kontrasepsi sehingga dapat mencapai waktu kehamilan yang direncanakan. Bagi wanita yang baru saja melahirkan, saat yang tepat untuk sebenarnya untuk melakukan KB yakni setelah persalinan sebelum meninggalkan ibu rumah sakit/klinik. Namun kondisi ini tergantung dari jenis alat/ metode KB yang dipilih ibu, serta apakah Ibu memiliki rencana menyusui bayinya atau tidak.

\section{Alat Kontrasepsi Paska Persalinan}

Terdapat beberapa metode KB yang cocok untuk ibu yang baru melahirkan:

1) KB metode non hormonal yang terdiri dari

a. Metode Amenore Laktasi (MAL)

b. Kondom

c. Alat kontrasepsi dalam rahim (AKDR)

d. Kontrasepsi mantap (tubekstomi atau vasektomi)

2) KB metode hormonal

Progestin yang berupa pil KB, suntik, dan implan 
Memilih alat atau metode KB sebaiknya dilakukan sejak masa kehamilan mengingat ada beberapa metode KB yang harus dilakukan langsung setelah persalinan.

a. Alat kontrasepsi IUD disarankan untuk dipasang segera setelah plasenta lahir hingga 48 jam setelah persalinan. Jika tidak, IUD baru bisa dilakukan 4 minggu setelahnya.

b. Kontrasepsi mantap atau tubektomi pada wanita. Jika memilih metode KB ini, idealnya dilakukan dalam 48 jam setealah persalinan dan jika tidak dapat dikerjakan dalam 1 minggu setelah persalinan ditunda 4-6 minggu setelahnya.

c. Metode amenore laktasi (MAL) ini sangat efektif. MAL merupakan metode kontrasepsi dengan cara menyusui. Pada saat ibu menyusui, hormon prolaktin akan meningkat. Peningkatan hormon ini akan mencegah terjadinya ovulasi sehingga haid/ menstruasi tidak datang pasca melahirkan (amenorea postpartum). Agar MAL dapat berkerja secara efektif, Ibu harus memberikan ASI secara eksklusif kepada bayi selama 6 bulan penuh, MAL tidak akan efektif lagi ketika bayi berusia 6 bulan dan mendapat asupan makanan lain, atau jika lbu telah mendapat haid kembali. Terkait dengan kondisi ini, pasangan disarankan untuk menggunakan alat kontrasepsi lainnya untuk melakukan KB

\subsection{Latihan/Senam Nifas}

Untuk mencapai hasil pemulihan otot yang maksimal, sebaikanya latihan senam nifas dilakukan sedini mungkin dengan catatan ibu menjalani persalinan dengan normal dan tidak ada penyulit post partum

Sebelum memulai bimbingan cara senam nifas, bidan sebaiknya menginformasikan manfaat dari senam nifas, pentingnya otot perut dan panggul kembali normal untuk mengurangi rasa sakit punggung yang biasa dialai oleh ibu nifas. 
Tujuan senam nifas di antaranya:

a. Mempercepat proses involusi uteri.

b. Mencegah komplikasi yang dapat timbul selama masa nifas.

c. Memperbaiki kekuatan otot perut, otot dasar panggul, serta otot pergerakan.

d. Menjaga kelancaran sirkulasi darah.

Manfaat senam nifas

a. Mempercepat proses penyembuhan uterus, perut, dan otot pelvis, serta organ yang mengalami trauma saat persalinan kembali ke kebentuk normal

b. Dapat memberikan manfaat psikologis dengan menambah kemampuan secara fisik, menciptakan suasana hati yang baik sehingga dapat menghindari stress, serta dapat bersantai untuk menghindari depresi pasca persalian.

Cara melakukan senam nifas

a. Latihan senam nifas

1) Hari pertama, tubuh terlentang dan rileks, kemudian lakukan pernafasan perut diawali dengan mengambil nafas melalui hidung dan tahan 3 detik kemudian buang melalui mulut, Lakukan 5-10 kali.

Manfaat :

Setelah melahirkan peredaran darah dan pernafasan belum kembali normal. Latihan pernafasan ini ditujukan untuk memperlancar peredaran darah dan pernafasan. Seluruh organ-organ tubuh akan teroksigenasi dengan baik sehingga hal ini juga akan membantu proses pemulihan tubuh

2) Hari kedua, sikap tubuh terlentang, Kedua tangan dibuka lebar hingga sejajar dengan bahu kemudian pertemukan 
kedua tangan tersebut tepat di atas muka. Lakukan 5-10 kali.

Manfaat : Latihan ini di tujukan untuk memulihakan dan menguatkan kembali otot-otot lengan.

3) Hari ketiga, sikap tubuh terlentang, kedua kaki agak dibengkokkan sehingga kedua telapak kaki berada dibawah. Lalu angkat pantat ibu dan tahan hingga hitungan ketiga lalu turunkan pantat keposisi semula. Ulangi 5-10 kali.

Manfaat : Latihan ini di tujukan untuk menguatkan kembali otot-otot daar panggul yang sebelumnya otot-otot ini bekerja dengan keras selama kehamilan dan persalinan.

4) Hari keempat, tidur terlentang dan kaki ditekuk $\pm 45^{\circ}$, kemudian salah satu tangan memegang perut setelah itu angkat tubuh ibu $\pm 45^{\circ}$ dan tahan hingga hitungan ketiga.

Manfaat : Latihan ini di tujukan untuk memulihakan dan menguatkan kembali otot-otot punggung.

5) Hari kelima, tidur terlentang, salah satu kaki ditekuk $\pm 45^{\circ}$, kemudian angkat tubuh dan tangan yang berseberangan dengan kaki yang ditekuk usahakan tangan menyentuh lutut. Gerakan ini dilakukan secara bergantian hingga 5 kali.

Manfaat : Latihan ini bertujuan untuk elatih sekaligus otot-otot tubuh diantaranya otot-otot punggung, otot-otot bagian perut, dan otot-otot paha.

6) Hari keenam, Sikap tubuh terlentang kemudian tarik kaki sehingga paha membentuk $90^{\circ}$ lakukan secara bergantian hingga 5 kali.

Manfaat : Latihan ini ditujukan untuk menguatkan otot-otot di kaki yang selama kehamilan menyangga 
beban yang berat. Selain itu untuk memperlancar sirkulasi di daerah kaki sehingga mengurangi resiko edema kaki.

Berikut ini beberapa contoh gerakan yang dapat dilakukan saat melakukan senam nifas :

1) Berbaring dengan lutut di tekuk. Tempatkan tangan diatas perut di bawah area iga-iga. Napas dalam dan lambat melalui hidung dan kemudian keluarkan melalui mulut, kencangkan dinding abdomen untuk membantu mengosongkan paru-paru

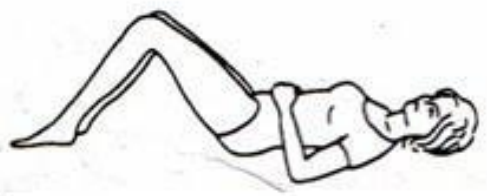

2) Berbaring telentang, lengan dikeataskan diatas kepala, telapak terbuka keatas. Kendurkan lengan kiri sedikit dan regangkan lengan kanan. Pada waktu yang bersamaaan rilekskan kaki kiri dan regangkan kaki kanan sehingga ada regangan penuh pada seluruh bagian kanan tubuh.
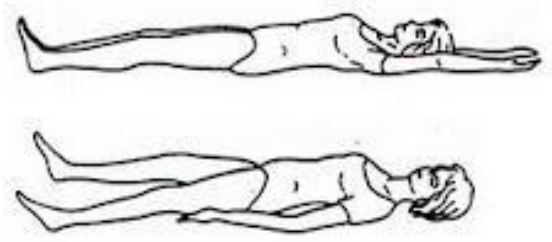
3) Kontraksi vagina. Berbaring telentang. Kedua kaki sedikit diregangkan. Tarik dasar panggul, tahan selama tiga detik dan kemudian rileks.

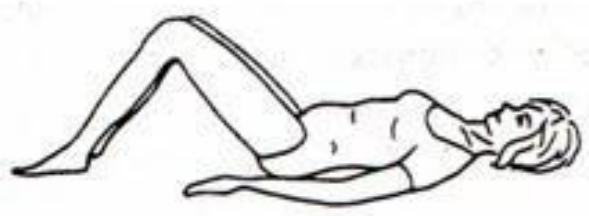

4) Memiringkan panggul. Berbaring, lutut ditekuk. Kontraksikan/kencangkan otot-otot perut sampai tulang punggung mendatar dan kencangkan otot-otot bokong tahan 3 detik kemudian rileks.

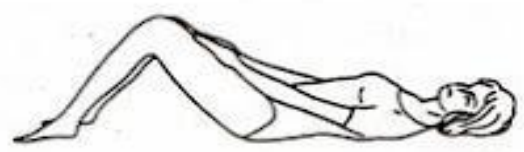

5) Berbaring telentang, lutut ditekuk, lengan dijulurkan ke lutut. Angkat kepala dan bahu kira-kira 45 derajat, tahan 3 detik dan rilekskan dengan perlahan.

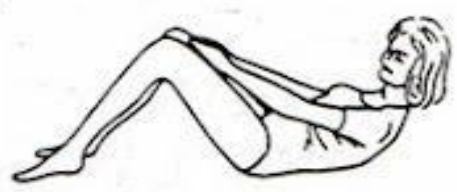

6) Posisi yang sama seperti diatas. Tempatkan lengan lurus di bagian luar lutut kiri. 


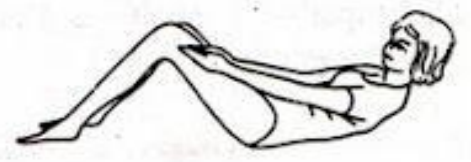

7) Tidur telentang, kedua lengan di bawah kepala dan kedua kaki diluruskan. angkat kedua kaki sehingga pinggul dan lutut mendekati badan semaksimal mungkin. Lalu luruskan dan angkat kaki kiri dan kanan vertical dan perlahan-lahan turunkan kembali ke lantai.

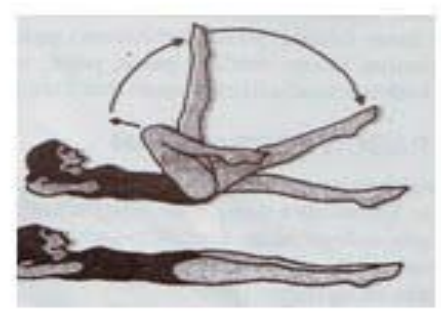

8) Tidur telentang dengan kaki terangkat ke atas, dengan jalan meletakkan kursi di ujung kasur, badan agak melengkung dengan letak pada dan kaki bawah lebih atas. Lakukan gerakan pada jari-jari kaki seperti mencakar dan meregangkan. Lakukan ini selama setengah menit. 


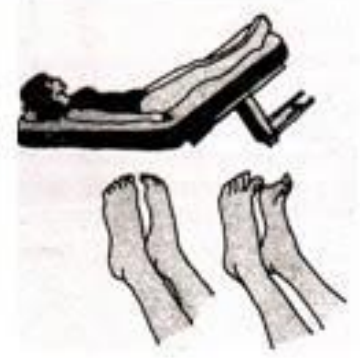

9) Gerakan ujung kaki secara teratur seperti lingkaran dari luar ke dalam dan dari dalam keluar. Lakukan gerakan ini selama setengah menit.

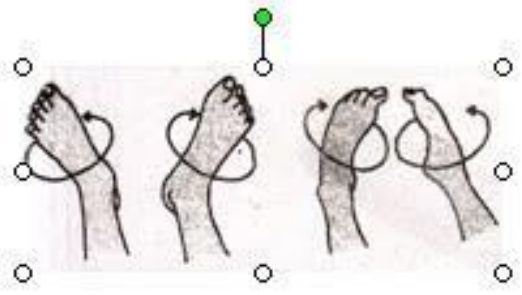

10) Lakukan gerakan telapak kaki kiri dan kanan ke atas dan ke bawah seperti gerakan menggergaji. Lakukan selama setengah menit.

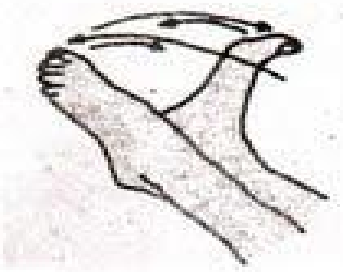

11) Tidur telentang kedua tangan bebas bergerak. Lakukan gerakan dimana lutut mendekati badan, bergantian kaki kiri 
dan kaki kanan, sedangkan tangan memegang ujung kaki, dan urutlah mulai dari ujung kaki sampai batas betis, lutut dan paha. Lakukan gerakan ini 8 sampai 10 setiap hari.

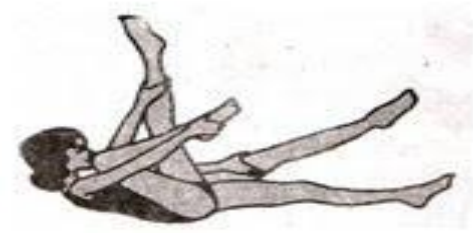

12) Berbaring telentang, kaki terangkan ke atas, kedua tangan di bawah kepala. Jepitlah bantal diantara kedua kakidan tekanlah sekuat-kkuatnya. Pada waktu bersamaan angkatlah pantat dari kasur dengan melengkungkan badan. Lakukan sebanyak 4 sampai 6 kali selama setengah menit.

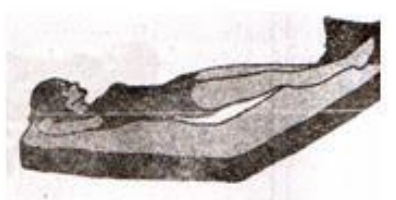

13) Tidur telentang, kaki terangkat ke atas, kedua lengan di samping badan. kaki kanan disilangkan di atas kaki kiri dan tekan yang kuat. Pada saat yang sama tegangkan kaki dan kendorkan lagi perlahan-lahan dalam gerakan selama 4 detik. Lakukanlah ini 4 sampai 6 kali selama setengah menit. 


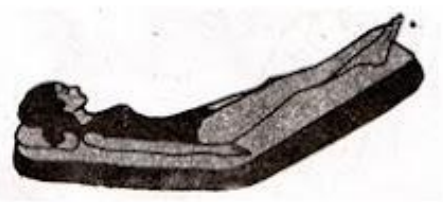

Tujuan latihan Sikap tubuh terlentang menarik kaki sehingga paha membentuk $90^{\circ}$

a. Menguatkan otot-otot punggung.

b. Menguatkan otot-otot di kaki dan memperlancar sirkulasi sehingga mengurangi resiko edema kaki

c. Menguatkan otot-otot bagian perut.

d. Menguatkan kembali otot-otot dasar panggul.

\section{Catatan :}

Bila ibu merasa pusing, merasa sangat lelah atau darah nifas yang keluar bertambah banyak, ibu sebaiknya menghentikan latihan senam nifas. Mulai lagi beberapa hari kemudian dan membatasi pada latihansenam yang dirasakan tidak terlalu melelahkan. 


\section{BAB 6 : Manajemen Kebidanan pada Ibu Nifas}

\section{Proses Manajemen Kebidanan}

Manajeman kebidanan adalah suatu proses pemecahan masalah yang digunakan sebagai metode untuk mengorganisasikan pikiran dan tindakan berdasarkan teori ilmiah, temuan dari hasil pemeriksaan, keterampilan dalam rangkaian/tahapan yang logis untuk mengambil suatu keputusan dalam penanganan klien.

Manajemen kebidanan dimulai dengan pengumpulan data sampai dengan evaluasi. Proses ini bersifat siklik (dapat berulang), dengan tahap evaluasi sebagai data awal pada siklus berikutnya. Proses manajemen kebidanan terdiri dari:

1. Pengumpulan data untuk menilai keadaan klien secara keseluruhan. Dalam pengumpulan data harus disesuaikan dengan kondisi pasien yakni data yang diambil terfokus untuk menunjang diagnosa pasien.

Kegiatan pengumpulan data dimulai saat pasien datang, data dapat dikumpulkan melalui 2 cara, yaitu wawancara (anamnesa) dari berbagai sumber, dan pemeriksaan melaui observasi kepada paisen. Wawancara dilakukan dengan Tanya jawab, pembicaraan terarah dengan cara tatap muka dan pertanyaan yang diajukan terarah kepada data yang relevan sesuai dengan kondisi pasien. Observasi dilakukan dengan melakukan pengumpulan data melalui indra penglihatan (perilaku pasien, ekspresi wajah, bau, suhu, dan lain-lain), dan pemeriksaan dengan menggunakan instrument tertentu.

2. Menginterpretasikan data untuk diagnosa atau masalah yang didapatkan dari hasil pemeriksaan melalui data subyektif dan obyektif.

3. Menyusun rencana asuhan secara menyeluruh serta Menetapkan kebutuhan terhadap tindakan segera, konsultasi, kolaborasi dengan tenaga kesehatan lain, serta rujukan berdasarkan kondisi klien 
4. Penatalaksanaan asuhan secara efisien dan aman sesuai dengan kondisi dan kebutuhan pasien.

5. Mengevaluasi keefektifan asuhan yang diberikan dengan mengulang kembali manajemen proses untuk aspek-aspek asuhan yang tidak efektif

\subsection{Pengkajian}

Pengkajian atau anamnesa adalah langkah pertama yang dilakukan untuk menggali informasi yang akurat dan lengkap dari semua sumber yang berkatian dengan kondisi pasien melalui pengajuan pertanyaan-pertanyaan terkait keluhan dan kondisi pasien.

Anamnesa dilakukan untuk memperoleh data pasien secara langsung. anamnesa juga dapat dilakuakan kepada keluarga pasien untuk memperoleh data tentang pasien. Hal ini dapat dilakukan pada keadaan darurat ketika pasien tidak memungkinkan lagi untuk memberikan data yang akurat.

Bagian-bagian penting dari anamnesa, antara lain:

\section{Data subjektif}

\section{a. Biodata}

Untuk mengetahui biodata pasien, bidan dapat menanyakan: Istri Suami

Nama

Nama

Umur

Umur

Agama

Agama

Pendidikan

Pendidikan

Pekerjaan

Pekerjaan 
Suku/Ras

Suku/Ras

Alamat

Alamat

b. Riwayat pasien

1) Keluhan utama

Keluhan utama dinyatakan untuk mengetahui alasan pasien datang ke fasilitas kesehatan. Misalnya, ibu postpartum normal ingin memeriksakan kesehatannya setelah persalinan. Contoh lain, ibu postpartum patologis dengan keluhan demam, keluar darah segar dan banyak, nyeri dan infeksi luka jahitan, dan lain-lain.

2) Riwayat kebidanan

Data ini penting untuk diketahui oleh tenaga kesehatan sebagai data acuan jika pasien mengalami kesulitan postpartum.

- Menstruasi

Data ini memang tidak secara langsung berhubungan dengan masa nifas, namun dari data yang bidan peroleh, bidan akan mempunyai gambaran tentang keadaan dasar dari organ reproduksinya.

Beberapa data yang harus bidan peroleh dari riwayat menstruasi, antara lain:

- Menarche

Menarche adalah usia pertama kali mengalami menstruasi. Pada wanita Indonesia, umumnya sekitar usia 12-16 tahun.

- $\quad$ Siklus

Siklus menstruasi adalah jarak antara menstruasi yang dialami dengan menstruasi berikutnya dalam hitungan hari. Biasanya sekitar 23-32 hari.

- Volume 
Data ini menjelaskan seberapa banyak darah menstruasi yang dikeluarkan. Kadang bidan akan kesulitan untuk mendapatkan data yang valid. Sebagai acuan, biasanya bidan menggunakan kriteria banyak, sedang, dan sedikit. Jawaban yang diberikan oleh pasien biasanya bersifat subjektif, namun bidan dapat menggali informasi lebih dalam lagi dengan beberapa pertanyaan pendukung, misalnya sampai berapa kali ganti pembalut dalam sehari.

- Keluhan

Beberapa wanita menyampaikan keluhan yang dirasakan ketika mengalami menstruasi, misalnya sakit yang sangat, pening sampai pingsan, atau jumlah darah yang banyak. Ada beberapa keluhan yang disampaikan oleh pasien dapat menunjuk kepada diagnosa tertentu.

- Gangguan kesehatan alat reproduksi

Data ini sangat penting untuk diketahui karena dapat memberikan petunjuk kepada bidan tentang organ reproduksinya. Ada beberapa penyakit organ reproduksi yang berkaitan erat dengan personal hygiene pasien atau kebiasaan lain yang tidak mendukung kesehatan reproduksinya. Jika didapatkan adanya salah satu atau beberapa riwayat gangguan kesehatan alat reproduksi maka bidan harus waspada adanya kemungkinan gangguan kesehatan alat reproduksi pada masa postpartum. Contohnya apakan pasien pernah mengalami gangguan, seperti keputihan, infeksi, gatal karena jamur, atau tumor.

- $\quad$ Riwayat kehamilan, persalinan, nifas, dan KB yang lalu

\begin{tabular}{|c|c|c|c|c|c|c|c|c|c|c|}
\hline \multirow{2}{*}{$\begin{array}{l}\text { Anak } \\
\text { ke }\end{array}$} & \multicolumn{2}{|c|}{ kehamilan } & \multicolumn{4}{|c|}{ Persalinan } & \multicolumn{2}{|l|}{ Nifas } & \multicolumn{2}{|l|}{ KB } \\
\hline & Lama & Penyulit & Penolong & Tempat & $\begin{array}{l}\text { BB } \\
\text { bayi }\end{array}$ & Penyulit & Vit A & Vit E & Alkon & Lama \\
\hline
\end{tabular}




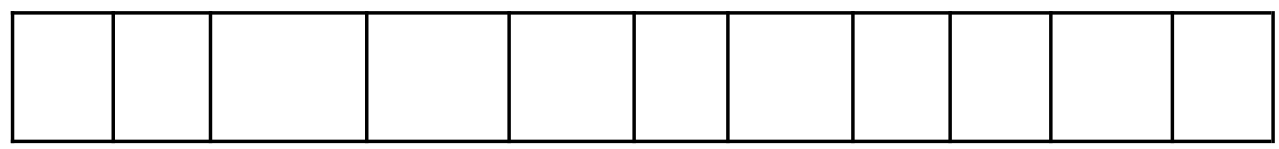

- Riwayat persalinan sekarang

\begin{tabular}{|l|l|l|l|l|l|l|l|l|l|}
\hline Penolong & Tempat & $\begin{array}{l}\text { Lama } \\
\text { kala 1 }\end{array}$ & $\begin{array}{l}\text { Lama } \\
\text { kala II }\end{array}$ & $\begin{array}{l}\text { Lama } \\
\text { kala III }\end{array}$ & $\begin{array}{l}\text { Perdarahan } \\
\text { kala IV }\end{array}$ & $\begin{array}{l}\text { BB } \\
\text { bayi }\end{array}$ & $\begin{array}{l}\text { Jenis } \\
\text { Kelamin }\end{array}$ & $\begin{array}{l}\text { Apgar } \\
\text { Score }\end{array}$ & ket \\
\hline & & & & & & & & & \\
\hline
\end{tabular}

3) Riwayat kesehatan

Data dari riwayat kesehatan tersebut dapat digunakan sebagai acuan kemungkinan adanya penyulit masa nifas. Adanya perubahan fisik secara fisiologis pada masa nifas dapat memengaruhi terjadinya gangguan/penyulit.

Data penting tentang riwayat kesehatan pasien yang perlu bidan ketahui, yaitu apakah pasien pernah atau sedang menderita penyakit, seperti penyakit jantung, diabetes mellitus, ginjal, hipertensi/hipotensi, atau hepatitis.

\section{4) Status perkawinan}

Hal ini penting untuk dikaji karena dari data inilah bidan mendapatkan gamabran mengenai suasana rumah tangga pasangan.

Beberapa pertanyaan yang dapat diajukan, antara lain:

- Usia nikah pertama kali

- Status pernikahan (sah/tidak)

- Lama pernikahan

- Ini adalah suami yang ke berapa

5) Pola makan 
Hal ini penting untuk diketahui, agar bidan mendapatkan gambaran bagaimana pasien mencukupi asupan gizinya. Bidan dapat menggali informasi dari pasien tentang makanan yang disukai dan yang tidak disukai, serta sebrapa banyak mengonsumsinya sehingga jika diperoleh data yang tidak sesuai dengan standar pemenuhan, maka bidan dapat memberikan klarifikasi dalam pemberian pendidikan kesehatan mengenai kebutuhan pemenuhan gizi ibu postpartum.

Bebapa hal yang perlu bidan tanyakan pada pasien, dalam kaitannya dengan pola makan, antara lain:

- Menu

Hal ini dikaitkan dengan pola diet berimbang bagi ibu postpartum. Jika pengaturan menu makan yang dilakukan oleh pasien kurang seimbang sehingga ada kemungkinan beberapa komponen gizi tidak akan terpenuhi maka bidan dapat memberikan pendidikan mengenai penyusunan menu seimbang bagi ibu.

Bidan dapat menanyakan pada pasien tentang apa saja yang ia makan dalam sehari (nasi, sayur, lauk, buah, makanan selingan, dan lain-lain)

- Frekuensi

Data ini akan memberikan petunjuk pada bidan tentang seberapa banyak asupan makanan yang dimakan

- Banyaknya

Data ini memberikan informasi tentang seberapa banyak makanan dalam satu kali waktu makan. Untuk mendapatkan gambaran total dari makanan, dikalikan dengan frekuensi makan dalam sehari

- Pantangan

Bidan juga harus dapat memperoleh data mengenai kebiasaan pasien dalam pemenuhan makanan yang justru 
sangat mendukung pemulihan fisiknya, misalnya daging, ikan, atau telur

6) Pola minum

Bidan juga harus dapat memperoleh data mengenai kebisaan pasien dalam pemenuhan kebutuhan cairannya, apalagi pada masa nifas sangat dibutuhkan cairan yang cukup

Yang perlu bidan tanyakan kepada pasien tentang pola minum, antara lain:

- Frekuensi

Bidan dapat menanyakan kepada pasien berapa kali ia minum dalam sehari dan dalam sekali minum dapat habis berapa gelas

- Jumlah per hari

Frekuensi minum dikalikan seberapa banyak dalam sekali minum akan diperoleh data jumlah in take cairran dalam sehari

- Jenis minuman

Kadang pasien mengonsumsi minuman yang sebenarnya kurang baik untuk kesehatannya, sehingga perlu ditanyakan jenis minuman yang biasanya dikonsumsi oleh pasien

7) Pola istirahat

Istirahat sangat dibutuhkan oleh ibu postpartum. Oleh karena itu, bidan perlu menggali informasi mengenai kebiasaan istirahat pada ibu supaya bidan mengetahui hambatan yang mungkin muncul jika bidan mendapatkan data yang senjang tentang pemenuhan kebutuhan istirahat. Bidan dapat menanyakan tentang berapa lama ibu tidur di siang dan malam hari. Pada kenyataannya, tidak semua wanita mempunyai kebiasaan tidur siang, padahal tidur siang sangat penting untuk membantu mempercepat 
pemulihan kondisi fisiknya setelah melahirkan. Untuk istirahat malam, rata-rata waktu yang diperlukan adalah 6-8 jam.

\section{8) Aktivitas sehari-hari}

Bidan perlu mengkaji aktivitas sehari-hari pasien karena data ini memberikan gambaran kepada bidan tentang seberapa berat aktivitas yang biasa dilakukan pasien di rumah. Jika kegiatan pasien terlalu berat sampai dikhawatirkan dapat menimbulkan kesulitan postpartum maka bidan segera memberikan peringatan pada pasien untuk membatasi dahulu kegiatannya sampai ia sehat dan pulih kembali. Aktivitas yang terlalu berat dapat menyebabkan perdarahan per vagina.

\section{9) Personal hygiene}

Data ini sangat penting untuk diketahui karena hal tersebut akan mempengaruhi kesehatan pasien dan bayinya. Jika pasien mempunyai kebiasaan yang kurang baik dalam perawatan kebersihan dirinya maka bidan harus dapat memberikan bimbingan cara perawatan kebersihan diri dan bayinya sedini mungkin.

Beberapa kebiasaan yang dilakukan dalam perawatan kebersihan diri, antara lain:

- Mandi

Kita dapat tanyakan kepada pasien berapa kali ia mandi dalam sehari dan kapan waktunya (jam berapa mandi pagi dan sore)

- Keramas

Pada beberapa wanita ada yang kurang peduli dengan kebiasaan keramas ini karena mereka beranggapan keramas tidak begitu berpengaruh terhadap kesehatannya. 
bidan harus memberikan pengertian bahwa keramas harus selalu dilakukan sewaktu rambut kotor.

- Ganti baju dan celana dalam

Ganti baju minimal sekali dalam sehari. Jika sewaktu-waktu baju dan celana dalam sudah kotor sebaiknya segera diganti tanpa harus menunggu waktu untuk ganti berikutnya.

- Kebersihan kuku

Kuku ibu postpartum harus selalu dalam keadaan pendek dan bersih. Kuku sebagai sarang kuman juga sumber infeksi, serta dapat menyebabkan trauma pada kulit bayi jika terlalu panjang. Bidan dapat mengajurkan pasien untuk memotong kukunya 2 kali dalam 1 minggu.

\section{0) Aktivitas seksual}

Walaupun hal ini merupakan hal yang cukup privasi bagi pasien, namun bidan harus menggali data dan kebiasaan ini agar tidak sampai terjadi gangguan dalam masa nifas. Bidan hendaknya memberikan konseling tentang kapan hubungan seksual pada masa nifas. Selama masa nifas pasien hendaknya tidak melakukan hubungan seksual, hubungan seksual dapat dilakukan saat masa nifas selesai, yakni ditandai dengan berhentinya perdarahan, dan sudah merasa siap.

\section{1) Keadaan lingkungan}

Keadaan lingkungan sangat memengaruhi status kesehatan keluarga. Beberapa data yang dapat bidan gali untuk memastikan keadaan kesehatan keluarga, antara lain:

- Fasilitas MCK

Bidan dapat menanyakan kepada pasien tentang kebiasaan buang air besar dan kecil sehari-hari di mana. Jika keluarga tidak mempunyai fasilitas MCK pribadi, apakah di sekitar 
tempat tinggal mereka ada fasilitas MCK umum atau mungkin mereka biasa buang air besar dan kecil di sungai

- Letak tempat tinggal dekat dengan kandang ternak atau tidak

Kandang ternak sangat memungkinkan untuk menularkan berbagai macam penyakit, apalagi jika kotoran hewan ternak tidak secara rutin dibersihkan. Bidan harus waspada bahaya penyakit infeksi yang awal penularannya melalui feses hewan. Bidan juga harus mengkaji jika keluarga pasien memelihara ternak, pastikan bahwa bayi tidak terganggu pernapasannya oleh debu sisa pakan ternak dan kotorannya

- Polusi udara

Bidan mengkaji apakah tempat tinggal pasien berada di pemukiman yang tingkat polusinya tinggi atau tidak. Untuk mengurangi tingkat polusi, bidan dapat menganjurkan pada pasien untuk menanam pohon di depan rumahnya, meskipun hanya memakai pot jika lahannya terbatas

- Keadaan kamar

Kamar yang sehat adalah jika sirkulasi udaranya lancar dengan ventilasi udara yang memungkinkan cahaya matahari masuk ke dalam kamar. Kamar yang lembab kurang baik untuk kesehatan bayi

12) Respon kluarga terhadap kelahiran bayi

Adanya respon yang positif dari keluarga terhadap kelahiran bayi akan mempercepat proses adaptasi ibu menerima perannya. Dalam mengkaji data ini, bidan dapat menanyakan langsung kepada pasien dan keluarga. Ekspresi wajah yang di tampilkan juga dapat memberikan 
petunjuk kepada bidan tentang bagaimana respon mereka terhadap kelahiran ini.

13) Respon ibu terhadap kelahiran bayinya

Dalam mengkaji data ini, bidan dapat menanyakan langsung kepada pasien mengenai bagaimana perasaannya terhadap kelahiran bayinya. Pertanyaan yang dapat bidan ajukan, misalnya "bagaimana mbak, perasaannya dengan kelahiran putranya ini?"

\section{4) Respon ayah terhadap bayi}

Untuk mengetahui bagaimana respon ayah terhadap kelahiran bayinya, bidan dapat menanyakan langsung kepada suami pasien atau kepada pasien. Data mengnenai respon ayah ini sangat penting karena dapat di jadikan sebagai salah satu acuan mengenai bagaimana pola bidan dalam memberikan asuhan kepada pasien dan bayinya. Jika suami pasien memberikan respon yang positif terhadap istri dan anaknya maka dapat memberikan kemudahan bagi bidan untuk melibatkannya dalam memberikan perawatan

15) Pengetahuan ibu tentang perawatan bayi

Data ini dapat bidan peroleh dari beberapa pertanyaan yang bidan ajukan kepada pasien mengenai perawatan bayi. Pengalaman atau riwayat kehamilannya dapat di jadikan sebagai bahan pertimbangan dalam menyimpulkan sejauh mana pasien mengetahui tentang perawatan bayi.

16) Perencanaan KB

Meskipun pemakaian alat kontrasepsi masih lama, namun tidak ada salahnya jika bidan mengkajinya lebih awal agar pasien mendapatkan informasi sebanyak mungkin mengenai pilihan beberapa alat kontrasepsi. Bidan juga 
dapat memberikan penjelasan mengenai alat kontrasepsi tertentu yang sesuai dengan kondisi dan keinginan pasien.

17) Latar belakang sosial budaya

Untuk mendapatkan data ini, bidan melakukan pendekatan terhadap keluarga pasien, terutama orang tua. Hal penting yang biasanya mereka anut kaitannya dengan masa nifas adalah menu makan untuk ibu nifas, misalnya ibu nifas harus pantang makanan yang berasal dari daging, ikan, telur, dan goring-gorengan karena dipercaya akan menghambat penyembuhan luka persalinan dan makanan ini akan membuat ASI menjadi lebih amis.

Adat ini akan sangat merugikan pasien karena justru permulihan kesehatannya akan terhambat. Dengan banyaknya jenis makanan yang dilakarang, hal tersebut juga dapat mengurangi nafsu makan ibu nifas sehingga asupan makanan yang seharusnya lebih banyak dari biasanya malah semakin berkurang. Produksi ASI juga dapat berkurang karena volume ASI sangat dipengaruhi oleh asupan nutrisi yang kualitas dan kuantitasnya cukup.

\section{Data objektif}

Untuk melengkapi data dalam menegakkan diagnosa, bidan harus melakukan pengkajian data objektif melalui pemeriksaan inspeksi, palpasi, auskulturasi, dan perkusi secara komprehensif.

Langkah-langkah pemeriksaan adalah sebagai berikut:

\section{1) Keadaan umum}

Untuk mengetahui data ini, bidan perlu mengamati keadaan pasien secara keseluruhan. Hasil pengamatan meliputi kriteria:

a. Baik

Pasien dimasukkan dalam kriteria ini jika pasien memperlihatkan respon yang baik terhadap lingkungan 
dan orang lain, serta secara fisik pasien tidak mengalami ketergantungan dalam berjalan

b. Lemah

Pasien dimasukkan dalam kriteria lemah jika kurang atau tidak memberikan respon yang baik terhadap lingkungan dan orang lain, serta pasien sudah tidak mampu lagi untuk berjalan sendiri

2) Kesadaran

Untuk mendapatkan gambaran tentang kesadaran pasien, bidan dapat melakukan pengkajian sssderajat kesadaran pasien dari keadaan composmentis (kesadaran maksimal) sampai dengan coma (pasien tidak dalam keadaan sadar)

3) Tanda vital

a. Tekanan darah

b. Nadi

c. Pernapasan

d. Suhu

4) Kepala

a. Rambut

- Warna

- Kebersihan

- Mudah rontok atau tidak

b. Telinga

- Kebersihan

- Gangguan pendengaran

c. Mata

- Konjungtiva

- Sclera

- Kebersihan

- Kelainan

- Gangguan penglihatan (rabun jauh/dekat)

d. Hidung 
- Kebersihan

- Polip

- Alergi debu

e. Mulut

- Bibir

o Warna

o Integritas jaringan (lembab, kering, pecah-pecah)

- Lidah

o Warna

o Kebersihan

- Gigi

o Kebersihan

o Karies

- Gangguan pada mulut (bau mulut)

5) Leher

a. Pembesaran kelenjar limfe

b. Parotitis

6) Dada
a. Bentuk
b. Simetris/tidak
c. Payudara
- Bentuk
- Gangguan
- ASI
- Keadaan putting
- Kebersihan
- Bentuk BH
d. Denyut jantung
e. Gangguan pernapasan (auskultasi)

7) Perut
a. Bentuk
b. Striae 

c. Linea
d. Kontraksi uterus
e. TFU

8) Eksternitas
a. Atas
- Gangguan/kelainan
- Bentuk

b. Bawah

- Bentuk

- Odem

- Varises

9) Genital

a. Kebersihan

b. Pengeluaran per vagina

c. Keadaan luka jahitan

d. Tanda-tanda infeksi vagina

10) Anus

a. Haemorrhoid

b. Kebersihan

11) Data penunjang

a. Laboratorium

- Kadar Hb

- Hmt (Haematokrit)

- Kadar leukosit

- Golongan darah

\subsection{Merumuskan Diagnose/Masalah Potensial}

Langkah selanjutnya setelah memperoleh data adalah melakukan analisis data dan interprestasi sehingga didapatkan rumusan diagnosis, berdasarkan data yang diperoleh, bidan akan memperoleh kesimpulan apakah masa nifas ibu normal atau tidak 
Berikut adalah beberapa dianosa potensial yang mungkin ditemukan pada pasien nifas. Kemungkinan masalah yang dialami oleh ibu adalah sebagai berikut :

1) Masalah nyeri, akibat luka jahitan perineum dll.

2) Masalah terjadi infeksi

3) Masalah psikologis ibu nifas (post partum blues, depresi post partum) dll.

4) Masalah kebutuhan iu pada masa nifas : kebutuhan KB, Gizi, tanda bahaya, senam nifas, dan proses laktasi.

Bidan juga harus mendeteksi masalah yang mungkin akan timbul pada ibu dengan merumuskan masalah potensial yang di dapatkan dari hasil pemeriksaan melalu data subyektif dan obyektif, masalah potensial tersebut belum terjadi, tetapi bidan harus sudah berpikir untuk mengantisipasi terjadinya masalah potensial. Kemungkinan masalah potensial yang akan dialami oleh ibu misalnya :

1) Gangguan perkemihan.

2) Gangguan $B A B$

3) Gangguan hubungan seksual.

4) Gangguan proses laktasi.

\subsection{Merencanakan Asuhan Kebidanan}

Berdasarkan diagnosis yang didapat, bidan dapat merencanakan asuhan pada ibu. Pada langkah ini rencana asuhan yang menyeluruh ditentukan oleh langkah-langkah sebelumnya (pengkajian data dan perumusan diagnosa).

1) Bidan harus melakukan evaluasi secara terus menerus terhadap ibu. Pantau kondisi ibu setiap 15 menit pada jam pertama dan setiap 30 menit pada jam kedua. Bidan tidak boleh meninggalkan ibu pada 2 jam pertama karena pada fase ini berbagai kemungkinan patologi/komplikasi dapat timbul. 
Perhatikan adanya tanda-tanda bahaya apapun pada ibu maupun bayi. Adanya kebijakan kunjungan masa nifas pada fase 6-8 jam, 6 hari, 2 minggu, dan 6 minggu pasca persalinan. Namun diluar jadwal kunjungan tersebut bidan harus memperhatikan kondisi ibu dengan memantau ibu sekali sehari untuk mengetahui kondisi ibu dan deteksi dini adanya komplikasi. Evaluasi secara terus menerus meliputi hal-hal sebagai berikut :

a. Meninjau ulang catatan persalinan, pengawasan, dan perkembangan sebelumnya, tanda-tanda vital, hasil laboratorium dan intervensi yang sudah diterima sebelumnya.

b. Mengkaji pemenuhan kebutuhan sehari-hari, psikologi ibu termasuk adakah ketidaknyamanan atau kecemasan yang dialamai, proses laktasi dan masalah yang dialami

c. Pemeriksaan fisik ibu. waspada perdarahan postpartum karena atonia uteri dengan melakukan observasi melekat pada kontraksi uterus selama 4 jam pertama postpartum dengan melakukan palpasi uterus

\section{2) Gangguan rasa nyeri}

Gangguan rasa nyeri pada masa nifas banyak dialami meskipun pada persalinan normal tanpa komplikasi. Hal tersebut menimbulkan ketidaknyamanan pada ibu. Bidan diharapkan dapat mengatasi gangguan ini dan memberikan kenyamanan pada ibu. Gangguan rasa nyeri yang dialami ibu, diantaranya adalah sebagai berikut.

a. After pain atau keram perut. Hal ini disebabkan kontraksi danrelaksasi yang terus menerus pada uterus, banyak terjadi pada multipara. Anjurkan untuk mengosongkan kandung kemih, tidur tengkurap dengan bantal dibawah perut, bila perlu diberi analgesik. 
b. Nyeri perineum

- beri analgesic oral (parasetamol 500 mg tiap 4 jam atau bila perlu)

- mandi dengan air hangat (walaupun hanya akan mengurangi sedikit rasa nyeri)

c. Nyeri punggung

- $\quad$ berikan obat pereda rasa nyeri (misalnya neurobion)

- lakukan fisioterapi (masase dan penyinaran)

- jaga postur tubuh yang baik (misalnya duduk selalu tegak)

d. Nyeri pada kaki

- lakukan kompres air hangat dan garam

- $\quad$ tidur posisi kaki lebih tinggi daripada badan

- masase kaki menggunakan minyak kelapa

e. Nyeri pada kepala

- berikan obat pereda rasa nyeri

- kompres air hangat di tengkuk

- masase pada punggung

f. Nyeri pada leher dan bahu

- $\quad$ kompres air hagant pada leher dan bahu

- masase bahu dan punggung

- usahakan posisi tidur yang nyaman dan istirahat cukup

3) Mencegah infeksi

Infeksi merupakan salah satu penyebab kematian ibu. Infeksi yang mungkin terjadi adalah infeksi luka jahitan perineum, infeksi pada genetalia, infeksi pada payudara (mastitis dan abses), infeksi saluran kencing. Untuk mengatasi infeksi

a. Kaji penyebab infeksi

b. Berikan antibiotika

c. Barikan roborantia

d. Tingkatkan supa gizi (diat tinggi kalori tinggi protein)

e. Tingkatkan in take cairan 
f. Usahakan istirahat yang cukup

g. Lakukan perawatan luka yang infeksi (jika penyebaba infeksi karena adanya luka yang terbuka)

4) mengatasi cemas

Rasa cemas sering timbul pada ibu saat masa nifas karena perubahan fisik dan emosi masih menyesuaikan diri dengan kehadiran bayi. Pada periode ini sering disebut "masa krisis" karena memerlukan banyak perhatian dan perubahan perilaku, nilai dan peran.

Tingkat kecemasan berbeda antar individu dengan yang lain. Bidan harus bersifat empati dalam memberikan dukungan secara mental pada ibu untuk mengatasi kecemasan. Asuhan ibu yang holistic tidak hanya berfokus pada kebutuhan fisik saja, tetapi juga psikisnya. Keadaan psikis dapat mempengaruhi fisik ibu. Atasi kecemasan dengan cara mendorong ibu untuk mengungkap perasaannya, libatkan suami dan keluarga untuk memberikan dukungan, dan berikan pendidikan kesehatan sesuai dengan kebutuhan ibu, sehingga dapat membangun kepercayaan diri dalam berperan sebagai ibu. Cara mengatasi cemas :

a. kaji penyebab cemas

b. libatkan keluarga dalam mengkaji penyebab cemas dan alternative penanganannya

c. berikan dukungan mental dan spiritual kepada pasien dan keluarga

d. fasilitasi kebutuhan pasien yang berkaitan dengan penyebab cemas:

- $\quad$ sebagai teman sekaligus pendengar yang baik

- sebagai konselor

- pendekatan yang bersifat spiritual

5) memberikan pendidikan kesehatan (health education) 
Pendidikan kesehatan pada ibu sangat diperlukan bagi ibu untuk bekal saat ibu berada dirumah. Pendidikan kesehatan yang diberikan berupa :

a. gizi

- tidak berpantang terhadap daging, telur, dan ikan

- banyak sayur dan buah

- banyak minum air putih, minimal 3 lliter sehari, terutama setelah menyusui

- tambahan kalori 500 mg sehari

- $\quad$ konsumsi tablet vitamin A dan zat besi selama nifas

b. personal hygienis

- kebersihan tubuh secara keseluruhan (mandi minimal 2 kali sehari)

- ganti baju minimal 1 kali sehari

- ganti celana dalam nominal 2 kali sehari

- keringkan kemaluan dengan lap bersihh setiap kali selesai buang air besar dan kecil, serta ganti pembalut minimal 3 kali sehari

- jaga kebersiahan kuku (kuku jangan sampai panjang)

- $\quad$ keramas minimal 1 kali sehari

- bersihkan peyudara terutama puting susu sebelum menyusui bayi

c. perawatan perineum

- usahakan luka selalu dalam keadaan kering (keringkan setiap kali buang air)

- hindari menyentuh luka perineum dengan tangan

- bersihkan kemaluan selalu dari arah depan ke belakang

- jaga kebersihan daerha perineum (ganti pembalut setiap kali sudah penuh atau minimal 3 kali sehari)

d. istirahat dan tidur

- istirahat malam 6-8 jam sehari

- istirahat siang 1-2 jam sehari

- tidurlah ketika bayi sedang tidur 
- $\quad$ tidurlah bersebalahan dengan bayi

e. ambulasi

- melakuakn aktivitas ringan sedini mungkin segera setelah partus

f. $K B$

- Kaji keinginan pasangan mengenai siklus reproduksi yang mereka inginkan

- Diskusikan dengan suami

- Jelaskan masing-masing metode alat kontrasepsi

- Pastikan pilihan alat kontrasepsi yang paling sesuai untuk mereka

g. Tanda bahaya

Tanda-tanda bahaya berikut merupakan hal yang sangat penting, yang harus disampaikan kepada ibu dan keluarga. Jika ia mengalami salah satu atau lebih keadaan berikut maka ia harus secepatnya datang ke bidan atau dokter

- Perdarahan per vagina yang luar biasa atau tiba-tiba bertambah banyak (lebih dari perdarahan haid biasa atau bila memerlukan ganti pembalut 2 kali dalam setengah jam)

- Pengeluaran per vagina yang berbau menusuk (menyengat)

- Rasa sakit di bagaian bawah abdomen atau punggung

- Rasa sakit kepala yang terus-menerus, nyeri epigastrik, atau masalah penglihatan

- Pembengkakan di wajah atau di tangan

- Demam, muntah, rasa sakit waktu buang air kecil, atau jika merasa tidak enak badan

- Payudara yang berubah menjadi merah, panas, dan sakit

- Kehilangan nafsu makan dalam jangka waktu yang lama

- Rasa sakit, warna merah, pembengkaakn di kaki

- Meresa sedih atau tidak mampu mengasuh bayi atau dirinya sendiri 
- Merasa sangat letih atau napas terengah-engah

h. Hubungan seksual

- Di awal-awal selesai masa nifas, lakukan hubungan seksual dengan hati-hati karena biasanya akan nyeri pada perineum

- Diskusikan dengan suami megenai pola dan teknik hubungan seksual yang nyaman

- Berikan pengertian pada suami mengenai kemungkinan keluhan yang akan dialami istri saat berhubungan seksual yang pertama kali setelah melahirkan

i. Senam nifas

Lakukan senam nifas dengan aturan senam sebagai berikut:

- Senam nifas dilakukan pada hari pertama postpartum

- Dilakukan 2 kali sehari

- Setiap macam gerakan dilakukan 5-10 kali

j. Perawatan bayi sehari-hari

- Pertahankan lingkungan bayi tetap hangat untuk menjaga supaya tidak terjadi penurunan suhu bayi

- Cegah iritasi kulit dengan selalu menjaga kebersihan tangan bayi atau pengasuh bayi

- Jika bayi mengalami iritasi kulit, hindari pemakaian bedak pada lokasi iritasi

- Olesi kulit yang iritasi dengan salep sesuai dengan resep dokter atau jika iritasi ringan cukup olesi dengan minyak kelapa bersih atau virgin coconut oil (VCO)

- Jaga kebersihan kulit bayi, hindari kult lembab dengan mengganti baju bayi minimal 2 kali sehari atau sewaktu-waktu ketika basah oleh keringat atau terkena muntahan

- Hindari menggosok kulit bayi terlalu keras ketika membersihkan daerah anus dan genital

- Jika ditemukan tanda-tanda alergi pada kulit, misalnya kemerahan dan berbintik-bintik, segera konsultasikan 
ke dokter dan hentikan untuk sementara produk sabun bayi yang digunakan

- Usahakan menjemur bayi tiap pagi antara pukul 06.30 sampai dengan 07.00 WIB

- Untuk kenyamanan bayi, pijat kaki dan tangan bayi menjelang tidur menggunakan baby oil

- Bersihkan selalu sekitar mulut bayi setiap kali memberikan minum pada bayi

- $\quad$ Hindari memijat daerah perut bayi

- Untuk menghindari trauma kulit bayi karena kuku bayi yang tajam dan panjang, usahakan selalu memakaikan sarung tangan pada bayi

- Pilih bahan baju yang tidak kaku dan menyerap keringat untuk bayi

- Sediakan selalu minyak telon/kayu putih sebagai antisipasi jika bayi mengalami gangguan perut (kembung) atau kedinginan

6) membantu ibu untuk menyusui bayi

ASI eksklusif selama 6 bulan sangat penting bagi bayi. Keberhasilan ASI eksklusif diawali dari bagaimana cara ibu mulai menyusui. Bagi ibu yang pertama kali mempunyai bayi diperlukan cara yang tepat dalam menyusui sehingga memperoleh kenyamanan bagi dirinya dan bayinya. Ajarkan pada ibu bagaimana cara menyusui yang baik dan bila ada masalah dalam menyusi dapat segera diatasi

- upayakan berada dalam posisi yang senyaman mungkin saat menyusui

- payudara dalam keadaan bersih

- lebih efektif jika posisi ibu duduk

- usahakan perut bayi menempel perut ibu

- sendawakan bayi setiap selesai menyusui

- menyusui minimal setiap 3 jam sekali atau setiap bayi meminta 
7) memfasilitasi menjadi orang tua

Ibu perlu menyesuaikan diri dengan peran barunya sebagai orang tua. Keberhasilan dalam penyesuaian diri pada fase ini akan mengurangi resiko terjadinya post partum blues. Salah satu kegiatan yang dilakukan oleh bidan adalah memfasilitasi ibu untuk menjadi orang tua

a. berikan dukungan dan keyakinan pada pasangan akan kemampuan mereka sebagai orang tua

b. upaya untuk belajar merawat bayi yang selama ini telah dilakukan sudah cukup bagus

c. perlu persiapan mental dan material karena anak adalah suatu anugerah sekaligus amanah yang harus dirawat sebaik-baiknya

d. dengan adanya anak akan mengubah beberapa pola dan kebiasaan sehari-hari, misalnya waktu istirahat, perhatian terhadap pasangan, komunikasi, tuntuntan dan tanggung jawab orang tua sebagai pendidik bagi anak

8) persiapan pasien pulang

Ketika pascapersalinan berlangsung normal, keadaan ibu dan bayi sehat, bidan dapat menentukan kapan ibu dapat dipulangkan. Sebelum dipulangkan, ibu dipersiapkan agar dapat menjalani kehidupan dirumah bersama bayi dan keluarga dalam keadaan aman. Persiapan sebelum ibu dipulangka $\mathrm{n}$ adalah sebagai berikut.

a. Pastikan ibu telah mengetahui tentang cara perawatan perineum, kebutuhan nutrisi ibu, personal hiegene, perawatan payudara, istirahat dan pendidikan kesehatan lainnya yang telah kita berikan selama ibu dirawat.

b. Beritahu ibu untuk segera menghubungi bidan bila terjadi tanda-tanda bahaya. Diantara tanda bahaya masa nifas adalah : perdarahan pervaginam, lokia berbau busuk, sakit kepala hebat, demem tinggi, bengkak pada wajah dan tangan, serta payudara 
merah panas dan sakit, beritahu dimana dan kapan menghubungi bidan atau petugas kesehatan.

c. Beri suplemen zat besi

d. Diskusikan tentang rencana kontrasepsi pascapersalinan.

e. Rencana kunjungan ulang untuk pascasalin lanjutan. Buat kesepakatan apakah ibu akan datang ke rumah atau bidan yang melakukan kunjungan rumah (home visite).

9) petunjuk antisipasi (antisipatory guidance)

Secara garis besar Anticipatory guidance meliputi instruksi dan bimbingan dalam mengantisipasi periode nifas dan bagaimana memberikan asuhan sepanjang masa nifas tersebut. Kebutuhan ibu nifas berbeda antara satu dengan yang lainnya dalam memberikan asuhan bidan harus menyesuaikan diri dengan kebutuhan ibu. Ibu nifas juga memberitahukan bidan jika terdapat hal-hal yang dibutuhkan sehingga dapat membantu bidan dalam hal memberikan asuhan yang lebih fokus. Anticipatory Guidance meliputi hubungan ibu dan bayi serta hubungan ibu dengan yang lainnya

a. ibu

- perawatan perineum

- perawatan payudara untuk ibu yang menyusui

- perawatan payudara selama pembesaran (distensi)

- latihan pengencangan abdomen

- latihan perineum

- aktivitas/latihan

- nutrisi

- istirahat

- personal hygiene

- normalitas baby blues

- tanda-tanda bahaya, meliputi:

o demam atau kedinginan

o perdarahan berlebih 
o nyeri abdomen

- nyeri berat atau bengkak pada payudara

- nyeri atau hangat pada betis, dengan atau tanpa edena tungkai

o depresi

- bagaimana menghubungi bidan atau sumber-sumber lain

- kapan kembali untuk mengevaluasi pasca partum atau kapan kontak melalui telepon

b. bayi

- $\quad$ informasi edukasi bagi ibu yang menyusui

- jika memberikan susu dari botol:

- penyiapan dan penyimpanan susu formula

- perawatan dan penyiapan botol dan dot susu

o bagaimana memegang bayi ketika memberi susu dengan botol

o bagaimana memegang botol ketika memberi susu

- menyendawakan

- memandikan bayi termasuk mengeramasi

- memakaikan pakaian:

- bagaimana memakaikan pakaian bayi

o berapa banyak pakaian yang harus disediakan sesuai dengan keadaan lingkungan dan suhu

- membersihkan dan merawat penis bagi bayi laki-laki

- perawatan perineum bagi bayi wanita

- perawatan tali pusat

- bagaimana mengangkat, memeluk, dan menggendong bayi

- bagaimana mengganti popok dan apa yang harus dilakukan dengan popok tersebut

- pencegahan dan penanganan ruam popok

- bagaimana mengukur suhu tubuh bayi dan bagaimana membaca thermometer 
- memberikan dot daripada membiarkan bayi menghisap jempol atau telapak tangan

- arti menangis:

o Lapar

- Perlu diganti popoknya

- Perlu diubah posisi atau posisi yang tidak nyaman

o Nyeri, mislanya sakit tertusuk peniti popok

o Perlu kasih saying (digending atau dibelai)

- Pakaian atau pembungkus terlalu ketat

- $\quad$ panggil orang yang memberikan perawatan pediatric atau bawa kedokter jika terjadi hal-hal berikut:

o Demam

o Diare

o Kongesti pernapasan

o Pemberian makan buruk

o Menangis akibat gelisah yang terus-menerus

o Icterus (bayi kuning)

- Perilaku lesu, tidak ada perhatian saat terjaga

- pentingnya check up dan imunisasi

c. ibu dalam hubungannya dengan orang lain

- sibling rivalry

- kebutuhan dan ketakutan pasangannya

- transisi hubungan keluarga

- $\mathrm{KB}$

- Memulai kembali hubungan seksual:

o Waktu untuk memulai kembali sangat ditentukan oleh kebutuhan dan kenyamanan

o Metode alternative untuk memuaskan kebutuhan seksual pada masa nifas

- Masalah privasi, gangguan, dan reflesk let down pada wanita menyusui

o Posisi alternative untuk hubungan seksual 
o Penggunaan preparat hormone atau pelumas untuk ketidaknyamanan

- Kebutuhan waktu untuk bersama dengan pasangannya dan berpisah dengan bayinya

10) Deteksi dini komplikasi pada ibu nifas.

Diperkirakan 60\% kematian akibat kehamilan terjadi setelah persalinan. $50 \%$ kematian nifas terjadi dalam 24 jam pertama. Bidan di tuntut untuk dapat melaksanakan asuhan kebidanan yang dapat mendeteksi dini komplikasi pada masa nifas

\subsection{Pelaksanaan Asuhan Kebidanan}

Pelaksanaan asuhan kebidanan dapat dilakukan dengan tindakan mandiri atau kolaborasi. Perlu juga adanya pengawasan pada masa nifas untuk memastikan kondisi ibu dan bayi dalam kondisi sehat. Berikan pendidikan/penyuluhan sesuai dengan perencanaan. Pastikan bahwa ibu telah mengikuti rencana yang telah disusun oleh bidan. Oleh karena itu dalam memberikan pelayanan bidan harus mendiskusikan dengan ibu dan keluarga sehingga pelaksanaan asuhan menjadi tanggung jawab bersama

Berikut ada beberapa contoh pelaksanaan dari perencanaan asuhan berdasarkan peran bidan dalam tindakan mandiri, kolaborasi, dan tindakan pengawasan.

a. Tindakan mandiri

- Pemantauan dalam 4 jam pertama postpartum (vital sign, tanda-tanda perdarahan)

- Perawatan ibu postpartum

- Bimbingan menyusui dini

- Bimbingan pemantauan kontraksi uterus kepada pasin dan keluarga

- Pemberian dukungan psikologis kepada pasien dan suami

- Pemberian pendidikan kesehatan 
- Pemberian tablet vitamin A dan zat besi roborantia

- Bimibingna cara perawatan payudara

- Bimbingan cara perawatan diri

b. Kolaborasi

- Dengan dokter ahli kandungan

o Penanganan perdarahan dan infeksi

- Dengan psikolog

- Penanganan depresi postpartum lanjut

o Penanganan dpresi karena kehilangan

- Dengan ahli gizi

o Penanganan anemi berat

- Upaya perbaikan status gizi pada ibu nifas dengan status gizi buruk

- Penanganan pada pasien yang mengalami kehilangan nafsi makan dalam jangka waktu yang lama

o Konsultasi penyusunan menu seimbang pada pasien vegetarian

- Konsultasi penyusunan menu seimbang pada pasien dengan keadaan tertentu (penyakit jantung, DM, infeksi kronis)

- Dengan ahli fisioterapi

o Penanganan pasien dengan keluhan nyeri pada otot yang berkepanjangan

- Pemulihan kondisi pasien setelah operasi sesar

- Dengan dokter ahli penyakit dalam

- Penanganan pasien dengan penyakit infeksi (misalnya, TBC, hepatitis, infeksi saluran pencernaan)

o Penanganan pasien HIV/AIDS

- Penanganan pasien dengan penyakit gangguan pernapasan

- Penanganan pasien dengan penyakit DM dan jantung

c. Tindakan pengawasan

- Pemantauan keadaan umum 
- Pemanatauan perdarahan

- Pemantauan tanda-tanda bahaya postpartum

- Pemantauan keadaan depresi postpartum

d. Pendidikan/penyuluhan

- Pasien

- Waspada tanda-tanda bahaya

- Perawatan diri dan bayi

- Gizi (in take cairan dan nutrisi)

o Kecukupan kebutuhan istirahat dan tidur

- Konsumsi vitamin dan tablet zat besi

- Cara menyusui yang benar

o Komunikasi dengan bayi

o Perawatan bayi sehari-hari

- Suami

- Pengambilan keputusan terhadap keadaan bahay istri dan bayi

- Pengambilan keputusan kebuthan istirahat dan nutri istri dan bayi

- Orang yang paling siaga dalam keadaan darurat istri dan bayi

- Dukungan yang positif bagi istri dalam keberhasilan proses adaptasi peran ibu dan proses menyusui

- Keluarga

- Pemberian dukungan mental bagi pasien dalam adaptasi peran dan proses menyusui

- Memfasilitasi kebutuhan istirahat dan tidur bagi pasien

- Mendukung pola makan yang seimbang bagi pasien

\subsection{Evaluasi}


Evaluasi dan asuhan kebidanan diperlukan untuk mengetahui keberhasilan yang diberikan. Evaluasi keefektifan asuhan yang diberikan apakah tindakan yang diberikan sesuai dengan perencanaan. Remncana tersebut dapat dianggap efektif jika memang benar efektif dalam pelaksanaanya. Evaluasi dapat dilakukan saat ibu melakukan kunjungan ulang. Saat itu dapat melakukan penilaian keberhasilan asuhan.

Untuk mengetahui sejauh mana keberhasilan asuhan yang bidan berikan kepada pasien, bidan mengacu pada beberapa pertimbangan antara lain:

1. Tujuan asuhan kebidanan

a. Meningkatkan, mempertahankan, dan mengembalikan kesehatan

b. Memfasilitasi ibu untuk merawat bayinya dengan rasa aman dan penuh percaya diri

c. Memastikan pola menyusui yang mampu meningkatkan perkembangan bayi

d. Meyakinkan ibu dan pasangannya untuk mengembangkan kemampuan mereka sebagai orang tua

e. Membantu keluarga untuk mengidentifikasi dan memenuhi kebutuhan mereka, serta mengemban tanggung jawab terhadap kesehatannya sendiri

2. Efektivitas tindakan untuk mengatasi masalah

Dalam melakukan evaluasi seberapa efektif tindakan dan asuhan yang akan bidan berikan kepada pasien, bidan perlu mengkaji respon pasien dan peningkatan kondisi yang bidan targetkan pada saat penyusunan perencanaan. Hasil pengkajian ini akan bidan jadikan sebagai acuan dalam pelaksanaan asuhan berikutnya.

3. Hasil asuhan

Hasil asuhan merupakan bentuk konkret dari perubahan kondisi pasien dan keluarga yang meliputi: pemulihan kondisi 
pasien, peningkatan kesejahteraan emosional, peningkatan pengetahuan, kemampuan pasien mengenai perawatan diri dan bayinya, serta peningkatan kemandirian pasien dan keluarga dalam memenuhi kebutuhan kesehatannya. 


\section{BAB 7 : Program Tindak Lanjut Asuhan Nifas di Rumah}

\subsection{Jadwal Kunjungan Rumah}

Jadwal kunjungan rumah bagi ibu postpartum mengacu pada kebijakan teknis pemerintah, yaitu 6 hari, 2 minggu, dan 6 minggu postpartum. Dari pemenuhan target pertemuan antara bidan dengan pasien sangat bervariasi, dapat dilakukan dengan mengunjungi rumah pasien atau pasien yang datang ke bidan atau RS ketika mengontrolkan kesehatan bayi dan dirinya.

Kualitas pertemuan yang lebih baik adalah jika tenaga kesehatan yang mengunjungi rumah pasien karena hasil dari evaluasi akan lebih lengkap dan valid. Bidan akan mengetahui dengan jelas baggaimana kemampuan ibu dalam melakukan perawatan bayinya sehari-hari dan kendala yang ia alami dengan kondisinya di rumah. Selain itu, informasi yang bidan sampaikan kepada keluarga pasien juga akan lebih mengena karena bidan akan dapat lebih mudah dalam menyesuaikan isi informasi dengan kondisi rumah dan lingkungannya, termasuk peluang adat yang belaku dalam masyarakat itu.

\subsection{Asuhan Lanjutan Masa Nifas di Rumah}

\section{Enam Hari Postpartum}

Biasanya pada periode 6 hari portpartum, pasienlah yang datang ke fasilitas pelayanan kesehatan untuk memeriksakan kesehatan dirinya sekaligus bayinya. Walaupun kenyataaannya kunjungan salahnya jika bidan coba menetapkan beberapa hal yang perlu bidan kaji kepada pasien.

Pada kunjungan pertama ini, yang perlu bidan kaji antara lain:

a. Memastikan, fundus di bawah umbiculus, tidak ada perdarahan abnormal, dan tidak ada bau 
b. Menilai adanya tanda-tanda demam, infeksi, atau perdarahan abnormal

c. Memastikan ibu mendapat cukup makanan, cairan, dan istirahat

d. Memastikan ibu menyusui dengan baik dan tidak memeperlihatkan tanda-tanda infeksi

e. Bagaimana peningkatan adaptasi pasien sebagai ibu dalam melaksanakan perannya di rumah

f. Bagaimana perawatan diri dan bayi sehari-hari, siapa yang membantu, sejauh mana ia membantu

Dari beberapa hasil penkajian tersebut, bentuk asuhan yang diberikan oleh bidan dalam kaitannya dengan perubahan psikologis ibu, antara lain:

a. Apabila terjadi baby blues maka bidan harus melakukan pendekatan kepada pasien dan keluarga, serta meingkatkan dukungan mental terhadap pasien dengan melibatkan keluarga

b. Menganjurkan dan memfasilitasi ibu untuk selalu berdekatan dengan bayinya

c. Membantu ibu untuk membiasakan menyusui sesuai permintaan bayi

d. Memberi pendidikan kesehatan kepada pasien dan keluarga mengenai pemenuhan kebutuhan nutrisi ibu dan istirahat yang cukup setelah melahirkan

\section{Dua Minggu Postpartum}

Dalam kunjungna ini, bidan perlu mengevaluasi ibu dan bayi. Pengkajian terhadap ibu meliputi:

a. Persepsinya tentang persalinan dan kelahiran, kemampuan kopingnya yang sekarang, dan bagamana ia merespon terhadap bayi barunya 
b. Kondisi payudara meliputi congesti, apakah ibu menyusui untuk mengurangi ketidaknyamanan. Selain itu, apakah ibu mengalami nyeri payudara

c. Asupan makanannya, baik kualitas maupun kuantitasnya

d. Nyeri, kram abdomen, fungsi bowel

e. Adanya kesulitan atau ketidaknyamanan dengan urinasi

f. Jumlah, warna, dan bau pendarahan lokia

g. Nyeri, pembengkakan perineum, dan jika ada jahitan, lihat kerapatan jahitan. Ibu mungkin perlu cermin dan memeriksanya sendiri atau meminta pasangannya untuk memeriksanya jika ia melaporkan adanya gejala-gejala tersebut

h. Adanya hemoroid dan tindakan kenyamanan yang digunakan

i. Adanya nyeri, edema, dan kemerahan pada ekstermitas bawah

j. Apakah ibu mendapatkan istirahat yang cukup baik pada siang maupun malam hari

k. Siapa yang ada untuk membantu ibu dengan manajemen rumah tanggnya dan bagaimana bantuan ini diberikan

I. Tingkat aktivitas saat ini, dalam hal perawatan bayi baru lahir, rumah tangga, dan latihan

m. Bagaimana keluarganya menyesuaikan diri dengan adanya bayi baru di rumah

n. Tingkat kepercayaan diri ibu saat ini dalam kemampuannya merawat bayi

o. Respon ibu terhadap bayi

p. Bagaimana kedudukan bayi dalam keluarga

q. Sumber-sumber di rumah

Pengkajian terhadap bayi meliputi:

a. Bagaimana dengan suplai ASI-nya, apakah ada kesulitan dalam menyusui

b. Pola berkemih dan buang air besar, termasuk frekuensinya 
c. Warna kulit bayi, ikterius atau sianosis

d. Keadaan tali pusat, tanda-tanda infeksi

e. Keadaan genital

f. Bagaimana bayi bereaksi terhadap lingkungan sekitarnya, termasuk apakah bayi dapat tidur dengan nyenyak, tidur pulas dan tampak puas setelah menyusu, sering menangis, sangat tajam perhatiannya saat terjaga, dan lain-lain.

Selain pengkajian dari anamnesa, bidan juga perlu melakukan pemeriksaan fisik singkat pada ibu dan bayi yang meliputi:

Pada ibu:

a. Tekanan darah

b. Suhu tubuh

c. Keadaan payudara

d. Pengkajian abdomen

e. Pemeriksaan perineum, termasuk pengkajian lokia Pada bayi:

a. Vital sign

b. Pemeriksaan tanda-tanda dehidrasi; turgor kulit; cekunganfontanel

c. Auskulturasi jantung dan paru-paru

d. Pemeriksaan tali pusat

e. Pemeriksaan sirkumsisi

f. Penapisan untuk icterus

g. Observasi responsivitas

h. Pengkajian kesejahteraan fisik dan kekuataan pernapasan

Bentuk asuhan yang diberukan dalam tahap ini antara lain

a. Mendorong suami dan keluarga untuk lebih memperhatikan ibu nifas

b. Memebrikan dukungan mental dan apresiasi atas apa yang telah dilakukan oleh ibu untuk menungkatkan kemampuan dan keterampilannya merawat bayi dan dirinya 
c. Memastikan tidak ada kesulitan dalam proses menyusui

3. Enam Minggu Postpartum

Pengkajian seperti pada kunjungan 2 minggu postpartum ditambahi:

a. Permulaan hubungan seksual -jumlah waktu, penggunaan kontrasepsi, dispareuni, kenikmatan, dan kepuasan wanita terhadap pasangannya

b. Metode KB yang diinginkan, riwayat KB yang lalu

c. Telepon ke bidan, dokter, dan RS mengenai masalah yang ada

d. Adanya gejala demam, kedinginan, pilek, dan sebagainya

e. Keadaan payudaraa

f. Fungsi perkemihan

g. Latihan pengencangan otot perut

h. Fungsi pencernaan, konstipasi, dan bagaimana penanganannya

i. Resolusi lokia, apakah haid sudah mulai lagi

j. Kram atau nyeri tungkai

\subsection{Penyuluhan Masa Nifas}

Di setiap kali pertemuan atau kunjungan ibu nifas, bidan harus selalu memasukkan kegiatan penyuluhan dalam perencanaan asuhan dengan pokok-pokok bahasan sebagi berikut:
a. Gizi
b. Suplemen zat besi dan vitamin A
c. Kebersihan diri dan bayi
d. Istirahat dan tidur
e. Pemberian ASI
f. Latihan/senam nifas
g. Hubungan seksual
h. KB
i. Tanda-tanda bahaya 
Isi dari materi penyuluhan selali disesuaikan dengan kondisi pasien, mulai dari berapa lama waktu setelah melahirkan, persalinan spontan atau tidak, paritas, sampai keadaan bayi normal atau tidak Soal latihan

a. Sebutkan keuntungan dari pelaksaan tindak lanjut asuhan nifas di rumah bagi bidan, pasien, dan keluarga

b. Sebutkan aspek-aspek apa saja yag harus dijaki ketika melakukan kunjungan rumah pasien nifas minggu ke-6

c. Apa saja yang harus dipersiapkan oleh bidan sebelum melakukan kunjungan pada pasien nifas

d. Jelaskan peran keluarga dan suami dalam proses asuhan nifas di rumah. 


\section{BAB 8 : Deteksi Dini Komplikasi Pada Masa Nifas Dan Penanganannya}

Komplikasi pada masa nifas biasanya jarang ditemukan selama pasien mendapatan asuhan yang berkualitas, mulai dari masa kehamilan sampai dengan masa persalinannya. Jika pasien sering bertatap muka dengan bidan melalui pemeriksaan antenatal maka bidan mempunyai lebih banyak kesempatan untuk melakukan penapisan terhadap berbagai kemungkinan komplikasi yang mungkin muncul pada masa inpartu dan nifas.

Beberapa kemungkinan komplikasi masa nifas dapat di deteksi oleh bidan secara dini melalui observasi, wawancara, maupun pemeriksaan.

\subsection{Perdarahan Pervaginan}

\section{1) Atonia Uteri}

Untuk melakukan penapisan terhadap kemungkinan komplikasi atonia uteri, bidan perlu mengkaji data yang relevan, yang meliputi :

a. Data subyektif

- Masa hamil
a) Umur pasien
b) Paritas
c) Jarak kelahiran anak
d) Social ekonomi
e) Pekerjaan (berat - ringannya aktivitas sehari-hari)
f) Riwayat kesehatan reproduksi
g) Pola pemenuhan kebutuhan nutrisi
h) Keluhan yang berhubungan dengan keadaan anemia defesiensi zat besi


- Dilanjutkan pada waktu inpartu
a) Semangat untuk melahirkan bayinya
b) Keluhan yang berhubungan dengan kekuatan tubuh (vitalitas, keadaan umum)
c) Perasaan capek, pandangan mata berkunang-kunang
d) Kontraksi yang tidak teratur.

b. Data Obyektif

- Mulai masa hamil
a) Keadaan umum
b) Kesadaran
c) Vital sign
d) Tanda-tanda anemia defisiensi zat besi (konjungtiva, warna kulit, warna ujung jari, kadar haemoglobin, dll)

e) Status gizi ibu hamil

f) Kenaikan berat badan

g) $\mathrm{djj}$

- Dilanjutkan pada waktu inpartu

a) Keadaan umum

b) Hasil pemantauan patograf (warning di garis waspada)

c) Proses kelahiran plasenta (spontan, dengan eksplorasi, waktu lahirnya plasenta, apakah lebih dari 1 jam)

d) Apakah persalinan dengan pacuan uterotonika.

e) Pemantauan kontraksi uterus di 2 jam post partum.

Gejala dan tanda syok berat :

1) Nadi lemah dan cepat (110/menit atau lebih). 
2) Tekanan darah sangat rendah : tekanan sistolik $<90 \mathrm{mmhg}$.

3) Napas cepat dengan frekuensi $30 \mathrm{kali} / \mathrm{menit}$ atau lebih

4) Urine kurang dari $30 \mathrm{cc} / \mathrm{jam}$

5) Bingung, gelisah, atau pingsan.

6) Berkeringat atau kulit menjadi dingin dan basah.

7) Pucat

c. Penatalaksanaan atonia uteri (mengacu pada standar pelayanan kebidanan):

- Berikan 10 unit oksitosin IM.

- Lakukan massase uterus untuk mengeluarkan gumpalan darah. Periksa lagi apakah plasenta utuh dengan teknik aseptic, menggunakan satung tangan DTT/steril, usap vagina dan ostium serviks untuk menghilangkan jaringan plasenta atau selaput ketuban yang tertinggal.

- Jika kandung kemih ibu dapat dipalpasi, gunakan teknik aseptic untuk memasang kateter kedalam kandung kemih.

- Lakukan kompresi bimanual internal maksimal 5 menit atau hingga perdarahan dapat dikendalikan dan uterus berkontraksi dengan baik.

- Anjurkan keluarga untuk memulai proses rujukan.

- Jika perdarahan dapat dikendalikan dan kontraksi mulai membaik maka :

a) Teruskan kompresi bimanual selama 1-2 menit atau lebih

b) Keluarkan tangan dari vagina dengan hati-hati.

c) Pantau kala IV persalinan dengan seksama, termasuk sering melakukan massase uterus untuk memeriksa atonia uteri, dengan mengamati Asuhan kebidanan III (Nifas) 125 
kontraksi dan perdarahan pervagina, serta tekanan darah dan nadi.

- Jika perdarahan tidak terkendali dan uterus tidak berkontraksi dengan baik dalam waktu 5 menit setelah dimulainya kompresi bimanual pada uterus maka :

a) Instruksikan salah satu anggota keluarga untuk melakukan kompresi bimanual interna

b) Keluarkan tangan dari dalam vagina dengan hati-hati

c) Jika tidak ada riwayat atau tanda ibu hipertensi maka berikan matergin $0,2 \mathrm{mg} \mathrm{IM}$.

d) Mulai pasang infus RL 500cc +20 unit oksitosin yang kedua.

e) Jika uterus tetap atoni dan/atau perdarahan masih tetap berlangsung, ulangi kompresi bimanual interna.

f) Jika uterus berkontraksi, rujuk segera ke tempat dimana operasi dapat dilakukan.

g) Dampingi ibu ke tempat rujukan. Teruskan infus RL dengan kecepatan 500cc/jam hingga ibu mendapatkan total 1.5 liter dan turunkan kecepatan hingga $125 \mathrm{cc} / \mathrm{jam}$.

- Jika ibu menunjukan gejala dan tanda syok maka rujuk segera dan lakukan tindakan berikut :

a) Jika infus belum diberikan, mulai berikan dengan instruksi sebagai berikut.

b) Pantau dengan cermat vital sign pasien setiap 15 menit

c) Baringkan ibu dengan posisi miring agar jalan napas ibu tetap terbuka dan meminimalkan resiko aspirasi jika ibu muntah. 
d) Selimuti ibu agar tetap hangat, tapi jangan membuat ibu kepanasan.

e) Jika munhgkin naikkan kakinya untuk meningkatkan darah kembali ke jantung.

- Bila perdarahan tetap berlangsung dengan kontraksi uterus tetap tidak ada maka kemungkinan terjadi rupture uteri (syok cepat tidak sebanding dengan darah yang keluar, abdomen teraba keras, dan fundus mulai naik) hal ini juga memerlukan rujakan ke rumah sakit segera.

- Bila kompresi bimanual tidak berhasil, cobalah kompresi aorta. Cara ini dilakukan pada keadaan darurat, sementara penyebab perdarahan masih dicari.

- Perkiraan jumlah darah yang keluar dan cek secara teratur vital sign.

- Buat catatan yang seksama tentang semua penilaian, tindakan yang dilakukan dan semua pengobatan yang sudah diberikan, termasuk pada saat pencatatan.

- Jika tidak dapat diperbaiki rujuk segera.

- Jika perdarahan dapat dikendalikan, ibu harus di observasi dengan ketat. Untuk menghindari terjadinya infeksi berikan antibiotika misalnya : ampisilin 1 gram IM, diikuti dengan 500mg per oral setiap 6 jam ditambah metronidazole 400-500mg per oral setiap 8 jam selama 5 hari.

\section{2) Robekan jalan lahir}

Untuk komplikasi ini, biasanya kejadiannya tidak terduga. Dalam waktu yang cepat, bidan harus melakukan tindakan 
penyelamatan sebelum ibu mengalami syok hypovolemic. Deteksi yang dapat dilakukan adalah senantiasa siaga saat melakukan pertolongan persalinan. Bidan dapat melakukan beberapa pengkajian yang dapat mendukung kea rah kemungkinan terjadinya komplikasi robekan jalan lahir, yang meliputi :

a. Data subyektif

- Masa hamil

a) Umur pasien

b) Paritas

b. Data obyektif

- Mulai masa hamil

a) Tinggi badan pasien

b) Taksiran berat janin

c) Elastisitas otot perineum melalui pemeriksaan ginekology.

d) presentasi

- Dilanjutkan pada waktu inpartu

a) Keadaan umum

b) Hasil pemantauan partograf (warning di garis waspada)

c) Elastisitas otot jalan lahir

d) Keterampilan mengejan pasien

e) Berat bayi lahir

f) Partus dengan tindakan (vacuum)

g) Pengeluaran darah pervagina.

c. Penatalaksanaan

- Kaji lokasi robekan jalan lahir

- Lakukan penjahitan segera sesuai dengan lokasi dan derajat robekan jalan lahir

- $\quad$ Pantau kondisi pasien (vital sign, dll) 
- Berikan antibiotika profilaksis dan robotania, serta diet TKTP (tinggi kalori tinggi protein)

\section{3) Retensio Plasenta}

a. Mulai masa hamil

- Data subyektif

a) Paritas

b) Umur

c) Riwayat persalinan sebelumnya

- Data obyektif

Hasil pemeriksaan ANC

b. Dilanjutkan dengan masa inpartu

- Data subyektif

- Pasien mengatakan belum merasakan mules setelah bayinya lahir

- Data obyektif

a) Perdarahan yang terjadi sebelum plasenta lahir lengkap

b) Uterus tidak berkontraksi

c) Plasenta tidak lahir selama 15 menit setelah bayi lahir.

- Penanganan

a. Jika plasenta tidak lahir dalam waktu 15 menit setelah bayi lahir maka ulangi penatalaksanaan kala III dengan memberikan oksitosin IM yang ke 2, lakukan peregangan tali pusat terkendali deangan hati-hati. Jika sampai 15 menit plasensta belum lahir, ibu tidak mengalami perdarahan hebat rujuk segera ke RS.

b. Jika terjadi perdarahan maka plasenta harus segera dilahirkan secara manual, bila tidak berhasil, segera rujuk ke RS. 
c. Berikan cairan IV : $\mathrm{NaCl} 0,9 \%$ atau $\mathrm{RL}$ dengan tetesan cepat jarum berlubang besar.

d. Siapkan peralatan untuk melakukan teknik manual plasenta yang harus dilakukan secara aseptic.

e. Baringkan ibu terlentang dengan lutut ditekuk dan kedua kaki ditempat tidur (dorsal recumbent)

f. Jelaskan pada ibu apa yang akan dilakukan dan jika ada berikan diazepam 10mg IM.

g. Lakukan cuci tangan bedah, kemudian pake sarug tangan bedah.

h. Masukkan tangan dengan hati-hati, jaga agar jari tetap merapat dan melengkung meliputi tali pusatsampai mencapai plasenta (pegang talu pusat dengan tangan kiri untuk membantu).

i. Ketika tangan sudah mencapai plasenta, letakkan tangan kiri diatas fundus uteri agar uterus tidak naik. Dengan tangan kanan yang masih dalam uteri, carilah tepi plasenta yang terlepas, telapak tangan kanan menghadap ke atas lalu lakukan gearakan mengikis ke samping untuk melepaskan plasenta dari dinding uterus.

j. Jika plasenta sdh lahir, segera lakukan masasse uterus, bila tidak ada kontraksi lakukan langkah penanganan pada atonia uteri.

k. Periksa plasenta dan selaputnya, jika tidak lengkap periksa lagi cavum uteri dan keluarkan potongan plasenta yang tertinggal.

I. Periksa robekan vagina, kemudian jahitan robekan. 
m. Jika tidak yakin plaasenta dapat terlahit semuanya, segera rujuk ibu ke RS.

n. Lakukan dokumentasi tindakan dan obat yang telah dibeikan.

\section{4) Tertinggalnya Sisa Plasenta}

Pengkajian dilakukan pada saat inpatu, bidan menentukan adanya retensio sisa plasenta jika menemukan adanya kotiledonyang tidak lengkap dan masih adanya perdarahan pervagina, padahal plasenta sudah lahir. Penanganan dilakukan sama dengan penanganan retensio plasenta.

5) Inversion uteri

Inversion uteri pada waktu persalinan biasanya disebabkan oleh kesalahan dalam memberi pertolongan pada kala III. Kejadian inversion uteri sering disertai adanya syok . perdarahan merupakan factor terjadinya syok, tetapi tanpa perdarahan syok tetap dapat terjadi karena tarikan kuat pada peritoneum, kedua ligamentum infundibulo-pelvikum, serta ligamentum rotundum. Syok dalam hal ini lebih banyak bersifat neurogenik. Pada kasus ini, tindakan operasi biasanya lebih dipertimbangakan, meskipun tidak menutup kemungkinan dilakukan reposisi uteri terlebih dahulu.

\subsection{Infeksi Masa Nifas}

Infeksi nifas mencakup semua peradangan yang disebabkan oleh masuknya kuman-kuman ke dalam genital pada waktu persalnan dan masa nifas. Menurut john committee on maternal welfare (amerika serikat), definnisi morbiditas puerpuralis adalah kenaikan suhu sampai $38^{\circ} \mathrm{C}$ atau lebih 
selama 2 hari dalam 10 hari harus diukur dari mulut setidaknya 4 kali sehari

Cara terjadinya infeksi

a. Tangan pemeriksa atau penolong yang tertutup sarung tangan pada pemeriksaan dalam atau operasi membawa bakteri yang sudah ada dalam vagina ke dalam uterus. Kemungkinan lain ialah bahwa sarung tangan atau alat-alat yang dimasukkan ke dalam jalan lahir tidak sepenuhnya bebas dari kuman.

b. Sarung tangan atau alat-alat terkena kontaminasi bakteri yang berasal dari hidung atau tenggorokan dokter atau perawat disekitarnya (droplet infection), oleh karena itu, hidung dan mulut petugas yang bekerja dikamar bersalian harus ditutup dengan masker, dan penderita infeksi saluran pernapasan dilarang memasuki kamar bersalin.

c. Dalam rumah sakit selalu banyak kuman-kuman pathogen yang berasal dari penderita-penderita dengan berbagai jenis infeksi. Kuman kuman ini bisa dibawah oleh aliran udara kemana-mana, antara lain ke handuk, kain-kain alat-alat yang suci hama, dan yang digunakan untuk merawat wanita dalam persalinan atau nifas.

d. Koitus pada akhir kehamilan tidak merupakan sebab infeksi penting, kecuali apabila mengakibatkan pecahnya ketuban.

e. Infeksi intrapartum sudah dapat menimbulkan gejala-gejala pada waktu berlangsungnya persalinan.

Faktor predisposisi terjadinya infeksi nifas : 
a. Semua keadaan yang dapat menurunkan daya tahan penderita, seperti perdarahan, pre eklamsi, eklampsi, dan juga infeksi lain.

b. Partus lama, terutama dengan ketuban pecah dini

c. Tindakan bedah vaginal, yang menyebabkan perlukaan jalan lahir.

d. Tertinggalnya sisa plasenta, selaput ketuban, dan bekuan darah.

Untuk penatalaksanaan infeksi masa nifas dengan tepat, perlu dikaji lokasi dan gejala infeksi.

1) Infeksi vulva, vagina dan serviks

a. Vulvitis

Pada luka infeksi bekas sayatan episiotomy atau luka perineum, jaringan sekitarnya membengkak, tepi luka menjadi merah dan bengkak, jahitan mudah terlepas, luka yang terbuka menjadi ulkus dan mengeluarkan pus.

b. Vaginitis

Infeksi vagina dapat terjadi secara langsung pada luka vagina atau melalui perineum. Permukaan mukosa membengkak dan kemerahan, terjadi ulkus, serta getah mengandung nanah yang keluar dari daerah ulkus. Penyebaran dapat terjadi, tetapi pada umumnya infeksi tinggal terbatas.

c. Servisitis

Infeksi serviks sering juga terjadi, akan tetapi biasanya tidak menimbulkan banyak gejala. Luka serviks yang dalam, luas, dan langsung ke dasar ligamentum latum dapat menyebabkan infeksi yang menjalar ke parametrium. 
Dari beberapa penjelasan tersebut data yang diperoleh dari pasien melalui proses pengkajian dapat disimpulkan sebagai berikut :

a. Rasa nyeri dan panas pada tempat infeksi

b. Kadang-kadang perih bila kencing.

c. Nadi dibawah $100 \mathrm{kali} / \mathrm{menit}$.

d. Getah radang dapat keluar.

e. Suhu sekitar $38^{\circ} \mathrm{C}$

f. Bila luka infeksi tertutup jahitan dan getah radang tidak dapat keluar, demam naik sampai $39^{\circ}-40^{\circ}$ di sertai menggigil.

Penanganan pada kasus ini merupakan pemberian antibiotik, roborantia, pemantauan vital sign take out pasien (makanan dan cairan).

2) Endometritis.

Jenis infeksi ini biasanya yang paling penting terjadi. Kuman-kuman yang memasuki endometrium, biasanya pada luka bekas implantasi plasenta dan dalam waktu singkat mengikutsertakan seluruh endometrium . pada infeksi dengan kuman yang tidak pathogen, infeksi hanya sebatas endometrium. Jaringan desidua bersama-sama dengan bekuan darah menjadi nekrotis dan akan mengeluarkan getah berbau, yang terdiri atas keping-keping nekrotis dan cairan. Pada batas-batas antara daerah yang beradang dengan daerah yang sehat, terdapat lapisan yang terdiri atas leukosit. Pada infeksi yang lebih berat, batas endometrium dapat dilampui maka infeksi akan menjalar. 

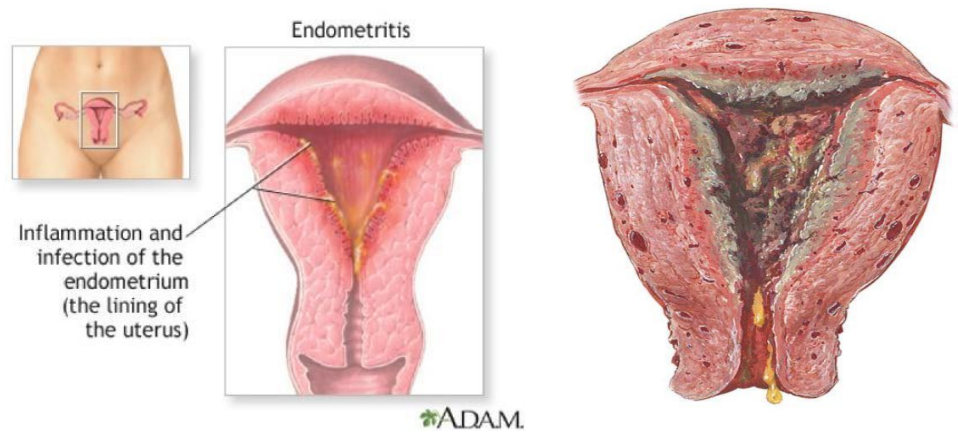

Gambar 8.1 : Endometritis (sumber : Anonimus 2017)

Dari hasil pengkajian, ditemukan data sebagai berikut :

a. Uterus membesar

b. Terasa nyeri saauterus di palpasi.

c. Uterus lembek suhu meningkat

d. Nadi menurun

3) Septikemia dan pyemia

Ini merupakan infeksi umum yang disebabkan oleh kuman-kuman yang sangat pathogen, biasanya streptococcus haemolyticus golongan A. Infeksi ini sangat berbahaya dan tergolong $50 \%$ penyebab kematian karena infeksi nifas.

a. Septicemia

Pada infeksi ini, kuman-kuman dari uterus langsung masuk ke dalam peredaran darah umum dan menyebabkan infeksi umum. Adanya septicemia dapat dibuktikan dengan jalan pembiakan kuman-kuman dari darah.

Gejala yang muncul dari pasien, antara lain:

- Permulaan penderita sudah sakit dan lemah 
- Sampai hari ke-3 postpartum, suhu meningkat dengan cepat dan menggigil

- Selanjutnya suhu berkisar antara 39-40 derajat, KU memburuk, nadi menjadi cepat (140-160 kali per menit)

b. Pyemia

Pada pyemia, terdapat thrombophlebitis dahulu pada vena-vena di uterus dan sinus-sinus pada bekas implantasi plaseta. Thrombophlebitis ini menjalar ke vena uterine, vena hipogastrika, dan/atau vena ovary. Dari tempat-tempat thrombus ini, embolus kecil yang berisi kuman dilepaskan. Tiap kali dilepaskan, embolus masuk ke dalam peredaran darah umum dan dibawa oleh aliran darah ke tempat-tempat lain, di antaranya paru-paru, ginjal, otak, jantung, dan sebagainya, yang dapat mengakibatkan terjadinya abses-abses di tempat tersebut.

Gejala yang dimunculkan adalah sebagai berikut:

- Perut nyeri

- Yang khas adalah suhu berulang-ulang meningkat dengan cepat disertai menggigil, kemudian diikuti dengan turunnya suhu

- Kenaikan suhu disertai menggigil terjadi pada saat dilepaskan embolus dari thrombophlebitis pelvika

- Lambat laun timbul gejala abses pada paru-paru, jantung, pneumoni, pleuritis

4) Peritonitis, salpingitis, dan ooforitis

a. Peritonitis

Infeksi nifas dapat menyebar melalui pembuluh limfe di dalam uterus, lagnsung mencapai peritoneum dan menyebabkan peritonitis atau melalui jaringan di antara kedua lembar ligamentum latum yang menyebabkan parametris. 
Peritonitis yang idak menjadi peritonitis umum hanya terbatas pada daerah pelvic. Gejala-gejalanya tidak seberapa berat seperti pada jenis yang umum. Pada pelvio peritonitis, terdapat pertumbuhan abses. Nanah yang biasanya terkumpul dalam cavum douglas harus dikeluarkan dengan kolpotomia posterior untuk mencegah keluarnya nanah melalui rectum atau kandung kemih.

Pada peritonis umum, gejala yang muncul:

- Suhu meningkat menjadi tinggi

- Nadi cepat dan kecil

- Perut kembung dan nyeri

- $\quad$ Ada defense musculair

- Muka penderita yang mula-mula kemerahan menjadi pucat, mata cekung, kulit muka dingin, terdapat apa yang disebut fasies hypocratica

Angka kematian ibu pada kasus ini sangat tinggi.

b. Salpingitis dan oofiritis

Kadang-kadang -walapun jarang-infeksi menjalar sampai ke tuba falopii, bahkan sampai ke ovarium. Di sinim terjadi salpingitis dan/atau ooforitis yang sukar dipisahkan dari pelvio peritonitis.

\section{Penanganan infeksi}

Antibiotika memegang peranan yang sangat penting dalam pengobatan infeksi nifas, asalkan pemilihan jenis antibiotika benar-benar berdasarkan hasil pertimbangan yang akurat. Pertimbangan dapat dilakukan melalui pembiakan getah vagina dan serviks sehingga kuman yang diketahui dapat dipastikan peka terhadap antibiotic tenterntu. Karena pemeriksaan pembiakan ini cukup memakan waktu, kadang pengobatan dengan antibiotic 
sudah dilakukan tanpa menunggu hasilnya terlebih dahulu. Dalam hal ini, dapat diberikan penicillin dalam dosis tinggi atau antibiotic dengan spectrum luas, seperti tetrasiklin.

Di samping antibiotika, pemberian roborantia untuk meningkatkan daya tahan tubuh pasien juga sangat perlu untuk diberikan. Pada selulitis pelvika dan pelvio peritonitis, perlu diamati dengan seksama aakah terjadi abses atau tidak. Jika terjadi maka abses harus dibuka untuk menghindari nanah masuk ke dalam rongga peritoneum dan pembuluh darah yang agak besar supaya jangan sampai dilukai.

\subsection{Sakit Kepala, Nyeri Epigastrikm dan Penglihatan Kabur}

1. Data subjektif

a. Ibu mengatakan kepalanya terasa sakit

b. Ibu mengatakan nyeri di daerah perut atas samping

c. Ibu mengatakan penglihatan kabur

d. Ibu mengatakan mual, bahkan sampai muntah

2. Data objektif

a. Ekspresi wajah ibu yang kelihatan menahan sakit

b. Mata dikerjap-kerjapkan supaya pandangannya lebih jelas

c. Vital sign: tekanan darah meningkat (lebih dari normal)

d. Kenikan berat badan yang drastic sejak kehamilan

e. Kaki odem dua-duanya

3. Pemeriksaan penunjangan/laboratorium

- Terdapat proteinuria Penanganan:

1. Pre eklampsi ringan

a. Rawat jalan

- Banyak istirahat

Asuhan kebidanan III (Nifas) 138 
- $\quad$ Diet TKTP

- Diet rendah garam, lemak, dan KH

- Konsumsi multivitamental sayuran dan buah

- Pemberian sedative ringan (diazepam 3 x2 mg) atau luminal 3 x $30 \mathrm{mg}$ selama seminggu

- $\quad$ Cek lab (HB, AL, Ct, Bt, Gold a, AT), darah kimia (alb, globulin, gula darah sewaktu, ureum cretinin, got, gpt)

- cek lab urine (uji faal hati, faal ginjal, estriol)

- control tiap minggu

b. Rawat Inap

- Dalam 2 minggu rawat jalan tidak menunjukkan perubahan

- BB bertambah

- Timbul salah satu tanda pre eklampsi berat

2. pre eklampsi berat

- Penderita dirawat di ruang yang tenang

- Diet cukup protein (100 gr per hari) dan kurang garam (0.5 gram per hari)

- Infus RL 125/jam (20 tetes per menit)

- $\mathrm{Mg}(\mathrm{SO})_{4}$

\subsection{Pembengkakan di Wajah Atau Eksternitas}

Pemeriksaan

a. Data subjektif

- Ibu mengatakan wajah dan kakinya membengkak

- Ibu mengatakan sesak nefas dan gampang capek

- Ibu mengatakan badan terasa lemas 
b. Data objektif

- $\quad$ KU kelihatan menurun (lemah)

- Vital sign: nadi kecil dan cepat, tensi turun, suhu normal, respirasi meningkat

- Terdapat odem pada wajah dan ekstremitas

- Pasien kelihatan pucat

- Ujung jari pucat sampai berwarna biru

- Aktivitas berkurang

- Berkeringat

c. Pemeriksaan penunjang

- Pemeriksaan EKG

Penanganan:

1. Perbanyak istirahat

2. Diet TKTP rendah garam

3. Pemantuan melekat vital sign

4. Rujuk ke ahli penyakit dalam (bagi seorang bidan) jika dalam RS lakukan kolaborsi dengan ahli lain (ahli penyakit dalam, ahli gizi)

\subsection{Demam, Muntah, Rasa Sakit Waktu Berkemih}

Pemeriksaan

a. Data subjektif

- Ibu mengatakan suhu badan naik dan menggigil

- Ibu mengatakan tidak enak badan

- Ibu mengatakan muntah setiap habis makan

- Ibu mengatakan sakit waktu kencing dan terasa panas

- Ibu mengatakan kalau kencing seperti anyang-anyangan

- Ibu mengatakan sakit mulai hari ke-5 setelah melahirkan

b. Data objektif

- Suhu badan meningkat

- Denyut nadi cepat 
- $\quad$ Sakit saat ditekan (nyeri tekan) di bagian atas simpisis pubis dan daerah lipat paha

c. Pemeriksaan laboratorium

- Jumlah lekosit meningkat

- Terdapat bakteri

Penanganan:

1. Pemberian parasetamol $500 \mathrm{mg}$ sebanyak 3-4 kali sehari

2. Antibiotic sesuai dengan mikroorganisme yang ditentukan

3. Minum yang banyak

4. Katerisasi bila perlu

5. Makan makanan yang bergizi

6. Jaga kebersihan daerah genitalia

\subsection{Payudara Berubah Menjadi Merah, Panas, dan Sakit}

1. Pembendungan air susu

Sesudah bayi lahir dan plasenta keluar, kadar estrogen dan progesterone turun dalam 2-3 hari. Dengan demikian, faktor dari hypothalamus yang menghalangi keluarnya prolactin waktu hamil sangat dipengaruhi oleh estrogen tidak dikeluarkan lagi dan terjedi sekresi prolektin oleh hypofisis.

Pada permulaan nifas, apabila bayi belum menyusu dengan baik, atau kemudian apabila kelenjar-kelenjar tidak dikosongkan dengan sempurna, terjadi pembendungan air susu. Payudara panas, keras, dan nyeri pada perabaan, serta suhu badan tidak naik. Putting susu mendatar dan ini dapat menyulitkan bayi untuk menyusu. Kadang-kadang pengeluaran susu juga terhalang duktus laktoferi yang menyempit karena pembesaran vena dan pembuluh limfa. Penanganan pembendungan dilakukan dengan jalan menyokong payudara dengan $\mathrm{BH}$ dan memebrikan analgetika. Kadang-kadang perlu diberi strilboestrol 3 kali 
sehari $1 \mathrm{mg}$ selama 2-3 hari (sementara waktu) untuk mengurangi pembendungan dan memungkingkan air susu dikeluarkan dengan pijatan.

2. Mastitis

Pada masa nifas dapat terjadi infeksi pada payudara, teruatama pada primipara. Infeksi terjadi melalui luka pada putting susu, tetapi mungkin juga melalui peredaran darah. Tanda-tandanya, antara lain:

a. Rasa panas dingin disertai dengan kenaikan suhu

b. Penderita merasa lesu

c. Tidak ada nafsu makan

Infeksi yang biasanya terjadi adalah staphylococcus aurcus, dengan tanda-tanda sebagai berikut:

a. Payudara membesar

b. Nyeri

c. Kulit merah pada suatu tempat

d. Memebengkak sedikit

e. Nyeri pada perabaan

Jika hal tersebut tidak lekas diberi pengobatan maka dapet terjadi abses.

Pencegahan:

a. Perawatan putting susu pada masa laktasi merupakan usaha penting untuk mencegah mastitis

b. Perawatan dengan cara membersihkan putting dengan minyak dan air hangat sebelum dan sesudah menyusui untuk menghilangkan kerak dan susu yang sudah mongering 
c. Bila ada reatk atau luka pada putting, sebaiknya bayi jangan menyusu pada bagian payudara yang sakit sampai luka sembuh. ASO deikeluarkan dengan pemijatan

Pengobatan:

a. Segera setelah mastitis ditemukan, pemberian susu kepada bayi dari payudara yang sakit dihentikan dan diberi antobiotik

b. Dengan tindakan-tindakan ini, terjadinya abses dapat dicegah karena biasanya infeksi disebabkan oleh staphylococcus aureus. Penisilin dalam dosis tinggi dapat diberikan.

c. Sebelum pemberian penisilin, dapat diadakan pembiakan ASI supaya penyebab mastitis dapat benar-benar diketahui

d. Bila ada abses, nanah perlu dikeluarkan dengan sayatan sedikit, mungkin pada abses. Untuk mencegah kerusakan pada duktus laktiferus, sayatab dibuat sejajar

\subsection{Kehilangan Nafsu Makan untuk Jangka Waktu yang Lama}

1. Analisa data

a. Ibu merasa trauma dengan persalinannya

b. Stress dengan perubahan bentuk tubuh yang tidak menarik lagi seperti dulu

c. Pada ibu post SC yang mual sampai muntah karena pengaruh obat anastesi dana keterbatasan aktivitas (terlalu lama dalam posisi berbaring, kepala sering pusing)

d. Adanya nyeri setelah melahirkan

2. Kemungkinan penyulit yang akan muncul

a. Pemenuhan kebutuhan nutrisi pada ibu nifas akan kurang 
b. Terjadi gangguan dalam proses laktasi dan menyusui

c. Kurang maksimalnya ibu dalam merawat bayinya

Penanganan:

a. Pemberian dukungan mental pada ibu

b. Pemberian KIE mengenai pentingnya asupan gizi yang baik untuk ibu dan bayinya

c. Kaji sejauh mana dukungan keluarga untuk mengatasi permasalahan ini

d. Fasilitasi dengan pemberian bimbingan dalam menyusun menu seimbang sesuai selera ibu

\subsection{Rasa Sakit, Merah, dan Pembengkakan Kaki}

Pemeriksaan

1. Data subjektif

a. Ibu mengatakan sakit pada tungkai bawah disertai pembengkakan

b. Ibu mengatakan susah berjalan

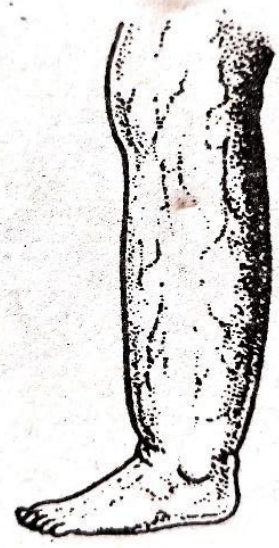

Gambar 8.2 : plegmasia alba dolen (sumber: Garrey Matthew \& Govan, 1974) 
2. Data objektif

a. Suhu badan subferis selama 7 hari meningkat mulai hari ke-10 sampai hari ke-20, yang disertai dengan menggigil dan nyeri sekali

b. Pada kaki yang terkena akan menunjukka tanda-tanda:

- Kaki sedikit dalam keadaan fleksi dan rotasi keluar, serta sukar bergerak, lebih panas dibandingkan dengan kaki satunya

- Seluruh bagian dari salah satu vena pada kaki terasa tegang dan keras pada paha bagian atas

- Nyeri hebat pada lipat paha dan daerha paha

- Reflex tonik akan terjadi spasme arteri sehingga kaki menjadi bengkak, tegang, putih, nyeri, dan dingin

- $\quad$ Edema kadang terjadi sebelum atau setelah nyeri dan pada umumnya terdapat pada paha, tetapi lebih sering dimulai dari jari-jari kaki dan pergelangan kaki, kemudian mulai dari bawah ke atas

- $\quad$ Nyero pada betis

3. Pemeriksaan penunjang

- Cek lab darah (lekosit) 


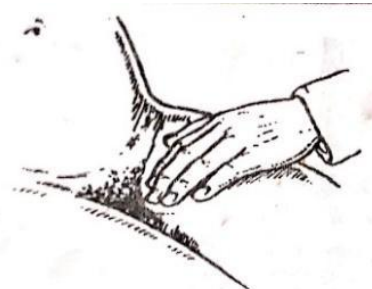

Palpasi atau perabaan di daerah vena femoralis untuk memastikan terjadinya

eS Scannthromboplebitis.

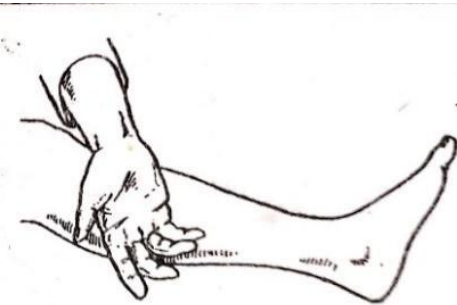

Pada palpasi menggunakan punggung tangan akan teraba suhu yang meningkat di tungkai bawah.

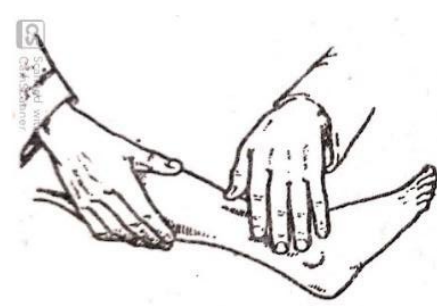

Palpasi pada ujung tungkai bawah akan terlihat adanya odem.

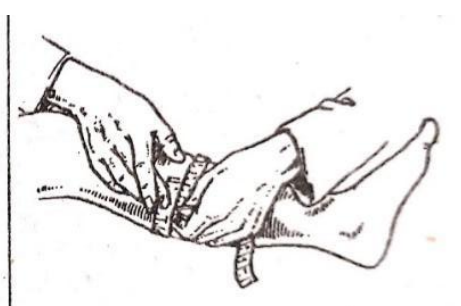

Pemeriksaan lingkar betis menggunakan metline akan memberikan petunjuk mengenai perbedaan diameter kaki yang terkena thromboplebitis dengan yang normal.

Gambar 8.3 : langkah-langkah pemeriksaan pada thrombophlebitis (sumber: Garrey Matthew \& Govan, 1974)

\section{Penanganan:}

\section{Perawatan}

a. Kaki ditinggikan untuk mengurangi edema, lakukan kompresi pada kaki

b. Kaki dibalut dengan elastic

2. Menyusui tetap dilanjutkan selama kondisi ibu masih memungkinkan

3. Tirah baring

4. Antibiotic dan analgetik 
5. Abtikoagulansia untuk mencegah bertambah luasnya thrombus dan mengurangi bahaya emboli (misalnya, heparin 10.000 satuan tiap 6 jam per infus, kemudian diteruskan dengan warfarin per oral)

\subsection{Merasa Sedih atau Tidak Mampu untuk Merawat Bayi dan Diri Sendiri}

1. Data subjektif

a. Riwayat persalinan (spontan/operasi)

b. Respon terhadap kelahiran bayinya

c. Kualitas pelayanan penolong persalinan

d. Riwayat perkawinan

e. Ibu anak ke...

f. Riwayat pola pendidikan ibu oleh orang tuanya

g. Karakter suami (bentuk dukungang psikologis)

h. Umuribu

i. Status pekerjaan dan pendidikan

j. Tingkat sosial ekonomi

k. Bagaimana dukungan keluarga

I. Respon masyarakat sekitar

2. Data objektif

a. Ekspresi wajah saat menceritakan tentang responnya terhadap kelahiran bayonya

b. Cara menyentuh bayinya

c. Kebersihan dirinya

d. Cara menyusui

e. Cara melakukan perawatan bayinya

f. Posisi tidur (bersebehalan dengan bayinya/tidak)

Penanganan: 
a. Memberikan dukungan mental kepada ibu dan keluarga

g. Memebrikan bimbingan cara perawatan bayi dan dirinya

h. Meyakinkan ibu bahwa ia pasti mampu melakukan perannya

i. Mendengarkan semua keluh-kesah ibu

j. Memfasilitasi suami dan keluarga dalam memberikan dukungan kepada ibu. 


\section{BAB 9 : Proses Laktasi dan Menyusui}

\subsection{Definisi ASI dan Laktasi}

Air Susu Ibu (ASI) merupakan cairan khusus yang kompleks, unik, serta dihasilkan oleh kelenjar kedua payudara. ASI merupakan cairan yang terbaik bagi bayi baru lahir hingga umur 6 bulan dikarenakan komponen ASI yang mudah dicerna dan diabsorbsi tubuh bayi baru lahir, dan memiliki kandungan nutrient terbaik dibandingkan dengan susu formula. Karakteristik ASI bervariasi, normalnya berwarna putih kekuningan, sedangkan Kolostrum merupakan ASI yang pertama kali keluar dan umunya berwarna kekuningan.

\subsection{Anatomi Fisiologi Payudara}

Payudara merupakan kelenjar mammae yang terbentuk pada minggu kelima kehidupan embrionik dari lapisan susu, lapisan jaringan glandular. Payudara yang terletak dibawah kulit diatas otot dada berfungsi untuk memproduksi ASI untuk kebutuhan nutrisi bayi. Berat payudara sebalum hamil 200gram, saat hamil 600gram, dan saat menyusui 800gram. Jaringan payudara ada dua bagian : parenkim dan stroma. Parenkim terdiri atas duktus laktiferous dimana bentuknya menyerupai cabang pohon yang terdapat pada struktur lobus alveolus hingga puting susu. Sedangkan stroma mencakup jaringan ikat, jaringan lemak (adiposa), pembuluh darah dan limfatik.

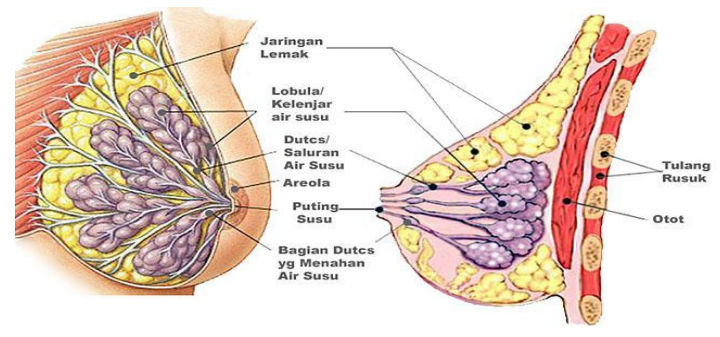


Gambar 9.1 anatomi payudara

Bagian-bagian payudara terdiri dari :

1. Alveoli (tempat produksi ASI)

a. Berbentuk seperti buah anggur

b. Dindingnya terdiri dari sel-sel yang memproduksi ASI, jika dirangsang oleh hormon prolaktin.

2. Duktus Lactiferous (saluran ASI)

a. Berfungsi untuk menyalurkan ASI dari alveoli menuju sinul laktiferus

3. Sinus lactiferous (tempat penyimpanan ASI)

Tempat penyimpanan ASI yang terletak dibawah areola

4. Myoepithel (otot polos)

a. Otot yang mengelilingi alveoli

b. Jika dirangsang oleh hormon oksitosin menyebabkan otot polos berkontraksi sehingga dapat mengeluarkan ASI.

c. Selanjutnya ASI mengalir melalui saluran payudara menuju sinus lactiferous.

\subsection{Fisologi Laktasi}

Laktasi merupakan proses produksi ASI dimana alveoli berada diantara lobus-lobus pada payudara dikelilingi oleh sel mioepitel yang dapat menstimulasi saraf diantara mioepitel sehingga menimbulkan kontraksi yang dapat merangsang pengeluaran ASI menuju duktus laktiferus. ASI disimpan didalam duktus laktiferus hingga terdapat rangsangan Milk Ejection Reflex (MER) akan menyebabkan sel mioepitel di sekeliling duktus laktiferus berkontraksi untuk pengeluaran ASI melalui puting payudara. Proses laktasi dipengaruhi oleh beberapa stimulus atau kontrol, diantaranya:

1) Kontrol fisik laktasi (Physical Control of Lactation)

Proses produksi ASI dipengaruhi oleh pengosongan payudara. 
Ketika payudara menjadi kosong dikarenakan pengeluaran ASI, dengan hisapan bayi secara otomatis payudara akan memproduksi ASI kembali. Pengosongan payudara yang tidak sempurna dapat menyebabkan produksi ASI menjadi berkurang. Kontrol ini disebut juga dengan kontrol autokrin (Milk Removal Driven). Fenomena tersebut menunjukkan bahwa proses produksi ASI merupakan proses yang dipengaruhi oleh supply-demand response, dimana terdapat proses kontrol produksi ASI sesuai dengan kebutuhan bayi. Mekanisme kontrol lokal ini mempunyai hubungan dengan proses pengosongan dan siklus pengisian alveoli payudara. Proses pengosongan payudara dapat dilakukan melalui dua teknik, yakni teknik pengeluaran ASI menggunakan teknik manual (hand expression) dan pompa ASI. Penelitian yang dilakukan oleh Morton et al.,(2009) menjelaskan bahwa teknik pengeluaran ASI melalui breast massage dan kompresi payudara sebelum melakukan pengeluaran ASI menggunakan hand expression efektif dalam meningkatkan proses pengosongan payudara. Hasil penelitian membuktikan produksi ASI pada wanita yang mendapatkan perlakuan lebih banyak dibandingkan dengan kelompok kontrol.

\section{2) Kontrol (Hormonal Control of Lactation)}

Produksi ASI dipengaruhi oleh kontrol hormon laktasi yakni hormon prolaktin dan oksitosin. Pada saat setelah plasenta lahir, terjadi penurunan kadar estrogen dan progesteron, sedangkan hormon prolaktin merupakan hormon yang berperan dalam produksi ASI mulai dari trimester akhir kehamilan sampai proses laktasi dimulai. Kadar hormon prolaktin dipengaruhi oleh proses pengosongan payudara yang sempurna serta hisapan bayi yang kdekuat dapat meningkatkan kadar prolaktin. Menurut penelitian yang dilakukan oleh Cox et al., (1996) dalam Riordan \& Wambach (2010) membuktikan bahwa frekuensi menyusui yang adekuat 
antara 8 sampai 12 kali dalam 24 jam dapat meningkatkan kadar prolaktin pada ibu yang menyusui, dan mampu meningkatkan level serum prolaktin.

Oksitosin merupakan hormon yang berperan dalam proses pengeluaran ASI dimana oksitosin akan merangsang terjadinya refleks let down. pengeluaran ASI dari alveoli menuju duktus lactiferus terjadi akibat refleks let-down atau disebut juga milk ejection reflex (MER). Akibat stimulus hisapan bayi, hipothalamus akan mengirimkan sinyal ke hipofisis posterior sehingga hipofisis posterior melepaskan oksitosin. Stimulasi oksitosin menyebabkan sel-sel mioepitel di sekitar alveoli di dalam kelenjar payudara berkontraksi. Kontraksi sel-sel mioepitel menyebabkan ASI keluar melalui duktus laktiferus menuju sinus laktiferus, dan siap dikeluarkan saat bayi menghisap bayi.

Pelepasan oksitosin dipengaruhi oleh rangsangan hisapan bayi yang dapat menimbulkan ereksi puting susu sehingga membantu pengeluaran ASI melalui sinus laktiferus menuju pori-pori puting susu. Selaian itu oksitosin juga merupakan hormon yang dapat merangsang kontraksi uterus selama persalinan dan selama post partum yang dapat mencegah terjadinya perdarahan post partum serta dapat mempercepat proses involusi uterus.

Refleks let-down atau disebut juga milk ejection reflex (MER) dapat mengalami peningkatan jika terdapat perasaan positif, pikiran positif, adanya bounding antara ibu dan bayinya, suara dan bau khas bayi yang dicium oleh ibu. Kecemasan, stress, nyeri pada wanita post partum juga dapat menurunkan MER 


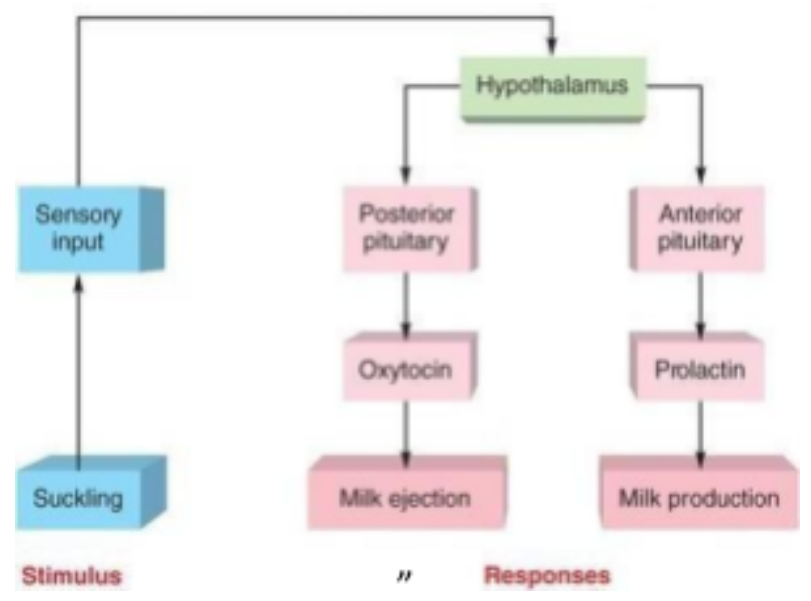

Gamnbar 10.2 fisiologi laktasi

3) Stimulasi sensori (sensory stimulation)

Proses laktasi juga dipengaruhi oleh stimulasi sensori pada ibu post partum yang menyusui bayinya. ibu post partum yang menyusui bayinya akan mengirimkan rangsangan sensori menuju sistem saraf pusat, misalnya ketika menyentuh bayinya, mencium aroma bayinya, mempunyai pikiran yang positif terhadap bayinya, atau ketika terdapat rangsangan sentuhan pada kulit ibu maupun pada area puting susu ibu. Hal ini didukung oleh penelitian yang dilakukan oleh Dr. Kerstin Uvnas- Moberg (1998) yang menjelaskan bahwa positif social behavior dan keterikatan fisik maupun emosional dapat mempengaruhi pelepasan oksitosin.

\subsection{Tahapan laktogenesis}

Minggu pertama post partum merupakan periode kritis yang mampu menentukan keberhasilan proses laktasi. Peningkatan produksi ASI umunya meningkat secara signifikan pada hari kedua dan ketiga post partum akibat penurunan kadar progesteron 
secara signifikan ketika memasuki tahapan laktogenesis II, tahapan laktasi antara lain :

1) Mammogenesis

Pada usia 16 minggu kehamilan, payudara sudah mampu memproduksi ASI. Proses produksi dan pengeluaran ASI pada kehamilan dihambat oleh tingginya level progesteron di dalam sirkulasi selama kehamilan yang dapat menghambat aktivasi prolaktin.

Pada tahapan mammogenesis terjadi pembesaran payudara, warna kulit di area payudara menjadi lebih gelap, pembuluh darah vena di sekitar payudara tampak menonjol, dan ukuran areola menjadi lebih lebar. Perubahan yang terjadi pada payudara merupakan proses yang fisiologis karena pengaruh hormon estrogen dan progesteron selama kehamilan menyebabkan pertumbuhan alveoli sehingga terjadi pembesaran payudara, kadar prolaktin mempengaruhi pertumbuhan puting dan pelebaran areola dipengaruhi oleh kadar serum laktogen plasenta.

2) Laktogenesis I

Proses transisi yakni perubahan bentuk dan fungsi payudara antara kehamilan dan laktasi disebut sebagai laktogenesis. Tahapan laktogenesis I dimulai pada saat kehamilan akhir sampai post partum hari kedua. Proses yang terjadi dalam tahap laktogenesis I yakni proses pembentukan ASI, proses diferensiasi sel alveoli dan sel sekretori pada payudara, dan terdapat stimulasi prolaktin sehingga sel epitel kelenjar payudara menghasilkan ASI.

3) Laktogenesis II

Tahapan laktogenesis II dimulai ketika terjadi penurunan kadar progesteron secara mendadak setelah plasenta dilahirkan. Proses laktogenesis II umunya terjadi pada hari ke-3-8 post partum. Proses yang terjadi dalam tahapan ini yakni 
perubahan dari kolostrum menjadi ASI dengan penurunan kadar sodium, klorida, dan protein serta terjadi peningkatan kadar lemak dan laktosa dalam ASI. Beberapa faktor dapat menghambat tahapan laktogenesis II diantaranya primipara, obesitas, dan ibu dengan diabetes mellitus. Keterlambatan tahapan laktogenesis II dapat menyebabkan kegagalan pemberian ASI eksklusif pada bayi baru lahir.

4) Galactopoiesis

Galaktopoiesis merupakan tahapan dimana terjadi pengaturan keseimbangan produksi ASI dimulai hari ke-9 post partum sampai awal tahap involusi. Payudara merupakan organ yang aktif, memproduksi ASI sesuai dengan kebutuhan (supply-demand response). Fenomena ini merupakan kontrol umpan balik yang mempengaruhi produksi ASI menyesuaikan dengan kebutuhan intake bayi. Semakin sering frekuensi menyusu maka produksi ASI akan meningkat. Galactopoiesis berlangsung selama ibu menyusui dan umumnya terjadi penururan ukuran payudara antara 6 bulan- 9 bulan post partum.

\subsection{Komposisi Nutrisi ASI}

Pada saat memasuki trimester ketiga kehamilan sampai awal persalinan payudara pertama kali menghasilkan cairan yang disebut kolostrum. Kolostrum merupakan cairan yang berwarna kuning keemasan dan mengandung banyak komponen antibodi, rendah lemak, tinggi protein, glukosa dan mineral apabila dibandingkan dengan komposisi ASI. Kolostrum diproduksi sebanyak 2 sampai 20 cc setiap kali ibu menyusui sampai hari ketiga post partum. Komposisi ASI berubah pada hari ketiga sampai hari kelima post partum. Jumlah kolostrum semakin berkurang dan ASI mengandung 20 kalori rata-rata per ons.

Komposisi ASI yang matur dibagi menjadi dua yakni foremilk dan 
hindmilk. Foremilk merupakan cairan ASI yang pertama kali keluar pada periode awal menyusui, dengan konsistensi yang encer, berwarna putih sedikit kebiru-biruan (bluish white foremilk). Foremilk mengandung laktosa, protein, vitamin larut air dan sebagian besar air. Hindmilk merupakan cairan ASI yang umumnya keluar setelah 20 sampai 30 menit dalam periode menyusui yang komposisinya lebih banyak mengandung lemak dan tinggi kalori dengan konsistensi lebih kental dan berwarna putih pekat bila dibandingkan dengan foremilk.

Berikut ini merupakan komponen utama ASI dan fungsinya :

1. Komponen ASI yang berfungsi sebagai kekebalan tubuh Air Susu Ibu mengandung berbagai komponen imunologi aktif yang dapat melindungi bayi dari agen infeksius seperti kuman, bakteri dan virus, dan mampu menurunkan resiko kematian pada bayi baru lahir. Komponen utama dari ASI yakni mengandung IgA dalam jumlah yang besar, IgM, IgG, IgD dan IgE yang berfungsi sebagai agen anti infeksi. ASI juga mengandung Limfosit T, Limfosit B, Sitokin, Kemokin, interleukin, bifidus factor, komplemen (C3-C4) dan lactoferin yang mampu merangsang aktivasi sistem imun, melakukan aktivitas imunologi dan mencegah infeksi lokal maupun sistemik yang disebabkan oleh patogen seperti bakteri dan virus.

2. Komponen protein dalam ASI

Komponen protein yang terdapat dalam ASI antara lain Whey (lactalbumin) dan kasein dengan perbandingan $60: 40$ pada ASI yang matur. Rasio perbandingan komposisi kedua bahan tersebut merupakan komposisi yang ideal dalam proses pencernaan bayi baru lahir karena mudah dicerna, menyebabkan konsistensi feses yang lunak, dan menimbulkan efek laksatif sehingga mencegah terjadinya konstipasi pada bayi baru lahir. Protein whey terdiri dari 
a-lactalbumin, serum albumin, laktoferin, imunoglobulin dan lisosim. Kandungan whey dan laktoferin di dalam ASI juga mampu mempunyai efek untuk melawan bakteri gram positif, bakteri aerob dan anaerob gram negatif, serta jamur.

3. Komponen enzim dalam ASI

ASI mengandung beberapa enzim yakni amilase, lipase, protease, ribonuklease yang berfungsi untuk membantu proses pencernaan dan absorbsi pada bayi baru lahir. Lisosim merupakan komponen utama ASI di dalam fragmen protein whey yang mempunyai efek bakteriosidal dan anti inflamasi. Lisosim bekerjasama dengan peroksida dan askorbat untuk menghancurkan bakteri Eschericia Colli dan beberapa jenis bakteri Salmonella. Lipase merupakan enzim yang berperan dalam proses pencernaan lemak dan merupakan komponen esensial dalam ASI Amilase merupakan komponen enzim didalam ASI yang berperan dalam proses pemecahan amilum bagi bayi baru lahir.

4. Komponen karbohidrat dalam ASI

Komponen utama karbohidrat dalam ASI adalah Laktosa. Laktosa merupakan disakarida yang membantu proses absorbsi kalsium dan di metabolisme menjadi galaktosa dan glukosa sehingga mampu mensuplai kebutuhan energi bagi bayi. Komponen karbohidrat lain yang terkandung dalam ASI yakni oligosakarida, galaktosa dan fruktosa. Hasil penelitian Dai et al.,(2000) dalam Riordan \& Wambach (2010) membuktikan bahwa oligosakarida berperan untuk membantu pertumbuhan laktobasilus bifidus yang dapat meningkatkan keasaman lambung sehingga mampu membunuh kuman patogen dan melindungi epitel usus bayi.

5. Komponen lemak dalam ASI

Komponen lemak yang terkandung dalam ASI antara lain: asam lemak bebas, rantai panjang asam lemak tak jenuh, 
trigliserida, dan kolesterol. Kolesterol merupakan komponen utama untuk pertumbuhan otak bayi. Lemak mempunyai kontribusi memberikan suplai energi sebesar $50 \%$ bagi bayi. Hasil penelitian Kent et al.,(2006) dalam Perry et al., (2010) membuktikan bahwa total kandungan lemak dalam ASI sebesar 22 sampai $62 \mathrm{gr} / \mathrm{L}$ dan tidak dipengaruhi oleh frekuensi menyusui. Komposisi lemak tertinggi dalam ASI terdapat dalam hindmilk. Rasio perbandingan kadar lemak antara hindmilk dan foremilk adalah 2:1. Komponen lemak yang lain dalam ASI yakni Long Chain Pollyunsaturated fatty Acids (LC- PUFA). Berdasarkan penelitian yang dilakukan oleh SanGiovanni et al (2000) dalam Vidayanti (2014) LC-PUFA mengandung docosahexanoid acid (DHA) dan arachinoid acid (AA) yang berhubungan dengan visual acuity dan kemampuan kognitif pada anak.

6. Komponen vitamin dan mikronutrien dalam ASI

ASI mengandung komponen vitamin dan mikronutrien yang lengkap dan sesuai dengan kebutuhan bayi. Komposisi vitamin dan mikronutrien yang terkandung didalam ASI bervariasi dan dipengaruhi oleh diet maternal dan perbedaan genetik. Vitamin yang terkandung didalam ASI antara lain : vitamin A, D, E, K, B12, B6 dan vitamin C. Vitamin A meningkatkan perkembangan proses penglihatan dan berperan dalam proses epitelisasi usus/ mukosa pada bayi. Vitamin D berperan dalam proses pembentukan tulang, vitamin $\mathrm{E}$ berfungsi sebagai antioksidan. Vitamin $\mathrm{K}$ berfungsi dalam proses pembekuan darah, vitamin $C$ dan vitamin B kompleks berperan untuk perkembangan sistem saraf pusat dan meningkatkan imunitas. Mikronutrien lain yang terkandung didalam ASI adalah mineral. Komposisi mineral dalam ASI antara lain : natrium, zink, zat besi, kalsium dan mineral lainnya. Rasio kalsium dan fosfor yang terkandung 
dalam ASI adalah 2:1. Perbandingan tersebut merupakan komposisi yang ideal untuk membantu proses mineralisasi tulang.

\subsection{Faktor-Faktor Yang Mempengaruhi Proses Laktogenesis}

Pengeluaran ASI pada ibu post partum umunya bervarisi. Kontrol laktasi dipengaruhi oleh hormonal, fisik, dan stimulus sensori pada wanita post partum. Berikut ini faktor yang mempengaruhi proses laktogenesis antara lain :

1) Faktor maternal yang mempengaruhi laktogenesis:

a. Paritas

Prolaktin merupakan hormon yang berperan dalam produksi ASI. Penelitian yang dilakukan oleh Zupa et al.,(1988) dalam Riordan \& Wambach (2010) menunjukkan bahwa wanita multipara memiliki reseptor prolaktin lebih banyak bila dibandingkan dengan primipara. Jumlah produksi ASI pada wanita multipara cenderung lebih banyak bila dibandingkan dengan primipara meskipun kadar prolaktin pada wanita multipara dan primipara cenderung sama pada hari keempat post partum.

b. Inisiasi menyusu dini

Inisiasi menyusu dini (IMD) merupakan salah satu faktor yang mempunyai peran penting dalam proses laktogenesis. IMD dapat dilakukan segera pada 1 jam pertama pasca kelahiran pada kondisi ibu dan bayi sehat, termasuk pada persalinan seksio sesarea. Proses IMD dapat mempererat ikatan perasaan antara ibu dan bayinya, Skin to skin contact antara ibu dan bayi segera setelah persalinan dapat meningkatkan ketenangan dan kenyamanan pada bayi. Rangsangan sentuhan di area sekitar dada merupakan stimulasi sensori yang dapat merangsang pengeluaran hormon oksitosin. Keberhasilan 
inisiasi menyusu dini dapat diidentifikasi saat bayi mampu meraih puting susu ibu serta dapat menghisap payudara ibu.

c. Frekuensi dan lama menyusui bayi

Frekuensi dan lama menyusui bayi sebaiknya menyesuaikan kebutuhan bayi atau on demand, karena dapat merangsang proses produksi ASI melalui stimulus hisapan bayi. Bayi umumnya menyusu dengan frekuensi 8-12 kali dalam waktu 24 jam. Lamanya bayi menyusu bervariasi dan umumnya berlangsung antara 20 sampai 30 menit dengan estimasi waktu minimal 15 menit untuk satu payudara. Bayi yang jarang menyusu dapat menyebabkan penurunan produksi ASI. Dan sebaliknya jika bayi sering menyusu maka produksi ASI akan semakin meningkat, karena hisapan bayi dapat mempengaruhi peningkatan pelepasan oksitosin dari hipofisis posterior dan peningkatan kadar prolaktin pada setiap tahapan laktogenesis.

d. Obesitas Maternal

Obesitas maternal diartikan sebagai keadaan indeks massa tubuh (IMT) ibu lebih dari $25 \mathrm{Kg} / \mathrm{m}^{2}$ yang diperoleh berdasarkan perhitungan berat badan ibu pada saat sebelum kehamilan dibagi dengan tinggi badan dalam meter yang dikuadratkan sesuai dengan kriteria IMT untuk ras Asia. Obesitas maternal memilki efek negatif terhadap durasi dan proses menyusui bayi. Obesitas selama usia reproduksi merupakan faktor resiko yang dapat menimbulkan beberapa komplikasi selama periode antenatal, perinatal, dan post partum. Selama kehamilan seorang wanita yang mengalami obesitas memiliki resiko yang lebih tinggi untuk mengalami diabetes mellitus 
gestasional, tromboemboli, preeklampsi yang juga meningkatkan resiko kematian pada periode kehamilan.

Faktor psikologis dan fisiologis pada ibu hamil dengan obesitas memiliki dampak terhadap pengalaman menyusui. Obesitas maternal merupakan salah satu faktor yang dapat menunda proses laktogenesis II yang ditunjukkan dengan keterlambatan pengeluaran ASI. Penelitian yang dilakukan oleh Nommsen- Rivers et al (2010) dalam Vidayanti (2014) menunjukkan hasil bahwa seorang wanita yang mengalami overweight (IMT $\geq 26$ sampai < 30) berpeluang 1,84 kali mengalami penundaan proses laktogenesis II dibandingkan dengan wanita hamil yang memiliki IMT normal. Ibu hamil dengan obesitas (IMT 230) memiliki peluang 2,21 kali mengalami penundaan laktogenesis II dibandingkan dengan Ibu hamil yang memiliki IMT normal. Penundaan proses laktogenesis II pada wanita yang mengalami obesitas dapat juga disebabkan karena penurunan kepercayaan diri ibu ketika proses menyusui, dukungan sosial yang rendah atau pengalaman yang tidak menyenangkan misalnya nyeri akibat seksio sesar dan kesulitan mobilisasi yang dialami oleh ibu dengan obesitas. Jevitt et al., 2007 dalam Vidayanti (2014) juga menyatakan bahwa wanita yang mengalami obesitas umumnya mengalami kesulitan dalam menyusui bayinya akibat bentuk putting yang inverted atau putting yang terlalu besar sehingga mempersulit proses perlekatan saat menyusui bayinya.

e. Rawat gabung

Prosedur rawat gabung (rooming-in) merupakan salah satu cara perawatan dimana ibu dan bayi yang dilahirkan bersama dalam sebuah ruangan selama 24 jam penuh. Kesiapan rawat gabung ditentukan oleh keadaan atau 
status kesehatan bayi dan kondisi kesehatan ibu serta kemampuan ibu untuk melakukan mobilisasi. Rawat gabung dapat dilakukan segera setelah bayi dilahirkan secara spontan atau SC, ibu dapat mulai menyusui bayinya sedini mungkin, kontak kulit ke kulit dalam proses bounding, sehingga membuat ibu merasa lebih tenang dan rileks hal tersebut dapat menstimulasi pengeluaran hormon oksitosin dari hipofisis posterior.

f. Usia ibu

Usia ibu yaitu usia individu yang terhitung mulai saat dilahirkan sampai saat berulang tahun. Dalam kurun waktu reproduksi sehat dikenal usia aman untuk kehamilan, persalinan, dan menyusui adalah 20-35 tahun. Kondisi tersebut juga sangat baik dan mendukung dalam pemberian ASI eksklusif, sedangkan umur yang kurang dari 20 tahun dianggap masih belum matang secara fisik, mental, dan psikologi dalam menghadapi kehamilan, persalinan, serta pemberian ASI. Ibu yang memproduksi ASI pada usia 20-35 tahun akan memproduksi ASI lebih lancar dibandingkan dengan ibu yang berusia lebih tua atau lebih muda ( $<20$ tahun atau $>35$ tahun).

g. Tingkat pendidikan

Tingkat pendidikan ibu yang rendah mengakibatkan kurangnya pengetahuan ibu dalam menghadapi masalah, terutama dalam pemberian ASI eksklusif. Pengetahuan diperoleh baik secara formal maupun informal, ibu yang mempunyai tingkat pendidikan yang lebih tinggi umumnya terbuka menerima perubahan atau hal-hal guna pemeliharaan kesehatanya. Pendidikan juga akan membuat seseorang terdorong untuk ingin tahu mencari pengalaman sehingga informasi yang diterima akan menjadi pengetahuan. 
Pendidikan merupakan upaya persuasif atau pembelajaran kepada masyarakat agar masyarakat mau melakukan tindakan dalam mengatasi masalah kesehatannya. Pendidikan diperkirakan ada kaitannya dengan pengetahuan ibu menyusui dalam memberikan ASI eksklusif, hal ini dihubungkan dengan tingkat pengetahuan ibu bahwa seseorang yang berpendidikan lebih tinggi akan mempunyai pengetahuan yang lebih luas dibandingkan dengan tingkat pendidikan yang rendah.

2) Faktor bayi yang mempengaruhi laktogenesis :

a. Kemampuan hisapan bayi

Kemampuan hisapan bayi dapat terjadi secara langsung atau bertahap menyesuaikan kecepatan aliran ASI yang dikeluarkan oleh ibu. ASI yang dikeluarkan melalui payudara ibu akan meningkatkan kecepatan hisapan bayi dan koordinasi bayi menelan, sebaliknya apabila kecepatan aliran ASI menurun maka kecepatan hisapan bayi juga akan menurun. Kecepatan dan kekuatan hisapan bayi juga merupakan faktor yang dapat mempengaruhi produksi ASI. Bayi dengan refleks hisap yang kuat akan mampu membuat puting berkontraksi dan merangsang hipofisis posterior untuk menghasilkan hormon oksitosin sehingga pengeluaran ASI menjadi optimal. Stimulus hisapan bayi juga mampu mengirimkan pesan ke hipotalamus yang merangsang hipofisis anterior untuk melepas prolaktin. Peningkatan prolaktin akan meningkatkan produksi ASI pada alveoli. Jumlah prolaktin yang disekresi dan jumlah ASI yang diproduksi berhubungan dengan besarnya stimulus hisapan bayi antara lain : frekuensi, intensitas, dan lamanya bayi menghisap.

b. Status Kesehatan Bayi (bayi dengan asfiksia) 
Bayi dengan kondisi APGAR score yang buruk atau dalam keadaan asfiksia sedang sampai berat perlu dirawat secara intensif dan memerlukan alat bantu pernapasan. Hal ini dapat mempengaruhi proses laktasi dikarenakan tidak memungkinkan dilakukan IMD dan rawat gabung, sehingga dapat memperlambat proses laktogenesis.

c. Kondisi Prematuritas atau Bayi Berat Lahir Rendah (BBLR) Bayi prematur seringkali mengalami permasalahan dalam proses menyusu karena memiliki refleks hisap yang lemah, kesulitan untuk mengkoordinasikan pernapasan, proses menghisap dan menelan dengan baik, selain itu bayi dengan prematur membutuhkan banyak waktu untuk istirahat dan proses menyusu akan membutuhkan ekstra energi bagi bayi prematur. Hal ini akan menyebabkan penundaan proses menyusui pada bayi prematur sehingga dapat menghambat stimulasi refleks let down.

\subsection{Perbedaan ASI}

ASI dibedakan dalam tiga stadium, yakni sebagai berikut :

1. Kolostrum

Cairan pertama yang diperoleh bayi pada ibunya adalah kolostrum, yang mengandung campuran kaya akan protein, mineral, dan antibody dibandingkan dengan ASI yang telah matang. ASI ada mulai ada kira-kira pada hari ke-3 atau hari ke-4. Kolostrum berubah menjadi ASI yang matang kira-kira 15 hari sesudah bayi lahir.

Kolostrum merupakan cairan dengan viskositas kental, dan berwarna kekuningan. Kolostrum mengandung tinggi protein, mineral, garam, vitamin A, nitrogen, sel darah putih, dan antibody yang tinggi daripada ASI matur. Selain itu, kolostrum masih mengandung rendah lemak dan laktosa. 
Protein utama pada kolostrum adalah immunoglobulin (IgG, IgA, dan IgM, yang digunakan sebagai antibody untuk mencegah dan menetralisir bakteri virus, jamur, dan parasit, meskipun kolostrum keluar sedikit menurut ukuran kita, tetapi volume kolostrum dapat memenuhi kapasitas lambung bayi yang berusia 1-2hari. Volume kolostrum antara $150-300 \mathrm{ml} / 24 \mathrm{jam}$. Kolostrum juga merupakan pencahar ideal untuk membersihkan zat yang tidak terpakai dari usus bayi baru lahir, serta dapat mempersiapkan saluran pencernaan bagi makanan bayi yang akan datang. ASI terdiri atas kira-kira $90 \%$ air sehingga bayi yang menyusu tidak membutuhkan cairan lain bagi tubuhnya.

2. ASI transisi/peralihan

ASI peralihan adalah ASI yang keluar setelah kolostrum sebelum ASI matang, yaitu sejak hari ke-4 sampai hari ke-10. Selama dua minggu, volume ASI bertambah banyak dan berubah warna, serta komposisinya. Kadar immunoglobulin dan protein menurun, sedangkan lemak dan laktosa meningkat.

3. ASI matur

ASI matur disekresi pada hari ke-10 dan seterusnya. ASI matur tampak berwarna putih. Kandungan ASI matur relative konstan, tidak menggumpal bila dipanaskan. ASI mengalir pertama kali atau saat lima menit pertama disebut foremilk. Foremilk lebih encer, serta mempunyai kandungan lemak, tinggi laktosa, gula, protein, mineral dan air. 

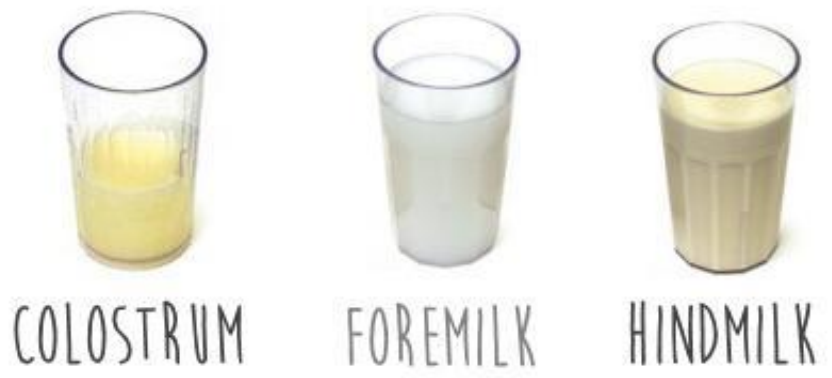

Gamabar 10.3 Perbedaan ASI (fiaindrikusumo, 2015) Selanjutnya, ASI berubah menjadi hindmilk. Hindmilk kaya akan lemak dan nutrisi. Hindmilk dapat membuat bayi cepat kenyang. Degan demikian bayi akan membutuhkan keduanya, baik foremilk maupun hindmilk. Padahal table berikut kita dapat melihat perbedaan komposisi antara kolostrum, ASI transisi, dan ASI matur.

Table 9.1 kandungan kolostrum, ASI transisi, dan ASI matur

\begin{tabular}{|l|c|c|c|}
\hline Kandungan & Kolostrum & ASI Transisi & ASI Matur \\
\hline Energy (kgkal) & 57,0 & 63,0 & 65,0 \\
\hline Laktosa $(\mathrm{gr} / 100 \mathrm{ml})$ & 6,5 & 6,7 & 7,0 \\
\hline Lemak $(\mathrm{gr} / 100 \mathrm{ml})$ & 2,9 & 3,6 & 3,8 \\
\hline Protein $(\mathrm{gr} / 100 \mathrm{ml})$ & 1,195 & 0,965 & 1,324 \\
\hline Mineral $(\mathrm{gr} / 100 \mathrm{ml})$ & 0,3 & 0,3 & 0,2 \\
\hline Immunoglobulin : & \multicolumn{5}{|l|}{} \\
\hline IgA $(\mathrm{gr} / 100 \mathrm{ml})$ & 335,9 & - & 119,6 \\
\hline IgG $(\mathrm{gr} / 100 \mathrm{ml})$ & 5,9 & - & 2,9 \\
\hline IgM $(\mathrm{gr} / 100 \mathrm{ml})$ & 17,1 & - & 2,9 \\
\hline Lisosin $(\mathrm{gr} / 100 \mathrm{ml})$ & $14,2-16,4$ & - & $24,3-27,5$ \\
\hline laktoferin & $420-520$ & - & $250-270$ \\
\hline
\end{tabular}

\subsection{Keuntungan Menyusui Bagi Ibu dan Bayi}


a. Pemberian ASI eksklusif mempunyai banyak manfaat bagi ibu, antara lain :

1) Mengurangi resiko kanker payudara bagi ibu

Penelitian oleh Martin et al.,(2005) mengevaluasi hubungan kejadian kanker payudara pada ibu yang tidak menyusui melalui survey pada 4000 wanita dewasa yang telah melahirkan dan menunjukkan hasil bahwa wanita yang menyusui secara eksklusif selama minimal 6 bulan mengalami penurunan resiko terkena kanker payudara. Penelitian Campbell (2013) dalam Vidayati (2014) menyatakan bahwa wanita yang tidak merokok dan menyusui bayinya secara eksklusif sampai 6 bulan dapat menurunkan resiko kanker payudara sebesar 4,3\%.

2) Mengurangi resiko kanker ovarium dan kanker rahim pada ibu

National Cancer Institute (2013) menyatakan bahwa proses kehamilan dan menyusui mempunyai hubungan dengan penurunan resiko kejadian kanker ovarium. Secara fisiologis pernyataan tersebut berhubungan dengan terhentinya proses ovulasi pada wanita yang menyusui atau wanita yang hamil. Penelitian yang dilakukan oleh Danfort et al.,(2013) Vidayati (2014) menunjukkan bahwa wanita yang menyusui bayinya selama 18 bulan menurunkan resiko kejadian kanker ovarium secara signifikan apabila dibandingkan dengan wanita yang tidak menyusui bayinya.

3) Mengurangi resiko osteoporosis pada ibu Kalsium merupakan komponen penting yang mempengaruhi proses pembentukan tulang dan mempertahankan kepadatan tulang. La Leche League International (2002) Vidayati (2014) menyatakan bahwa seorang ibu yang menyusui bayinya secara eksklusif 
akan menurunkan kejadian resiko osteoporosis. Hal ini didukung oleh penelitian yang dilakukan Karlson et al., 2005 Vidayati (2014) yang menunjukkan bahwa wanita yang menyusui bayinya mempunyai kepadatan tulang sama dengan wanita yang tidak menyusui bayinya.

4) Mengurangi resiko diabetes maternal

Studi yang dilakukan oleh Harvard University oleh Stuebe et al 2005 menunjukkan bahwa wanita yang menyusui bayinya secara eksklusif dapat menurunkan resiko diabetes tipe II sebesar $15 \%$ dibandingkan wanita yang tidak menyusui. Hal ini didukung oleh penelitian yang dilakukan oleh Schwarz et al (2010) Vidayati (2014) membuktikan bahwa proses laktasi berhubungan dengan peningkatan metabolisme glukosa maternal dan wanita yang menyusui bayinya secara eksklusif lebih dari satu bulan mempunyai resiko lebih rendah menderita diabetes mellitus tipe II dibandingkan dengan ibu yang tidak menyusui bayinya.

5) Mengurangi stress dan gelisah pada ibu Penelitian yang dilakukan oleh Groer (2005) Vidayati (2014) membandingkan respon emosional dari 88 wanita yang menyusui secara eksklusif, 99 wanita yang tidak menyusui eksklusif dan menggunakan susu formula, dan 33 wanita sehat yang tidak melahirkan. Hasil penelitian menunjukkan bahwa wanita yang menyusui secara eksklusif cenderung memiliki mood positif, peristiwa positif, dan kejadian stres yang lebih rendah bila dibandingkan dengan kedua kelompok pembanding lainnya. Selain itu, ibu yang menyusui bayinya mempunyai tingkat stres dan depresi yang lebih rendah bila dibandingkan dengan ibu yang tidak menyusui bayinya. 
6) Berat badan ibu lebih cepat kembali normal

Penelitian yang dilakukan oleh Kac G et al., 2004 menunjukkan hasil bahwa wanita yang menyusui bayinya selama 6 bulan mengalami penurunan berat badan rata-rata $0,44 \mathrm{~kg}$ bila dibandingkan dengan wanita yang menyusui bayinya selama satu bulan. Semakin lama wanita menyusui bayinya maka penurunan retensi berat badan akan lebih signifikan dibandingkan wanita yang tidak menyusui sehingga dapat mempengaruhi berat badan wanita menjadi normal.

7) Membantu proses penundaan kehamilan

Selama periode menyusui kadar prolaktin serum pada wanita yang menyusui bayinya akan meningkat. Seorang wanita yang menyusui secara eksklusif akan mengalami amenorea karena terjadi proses penundaan ovulasi akibat proses inhibisi respon ovarium terhadap pelepasan follicle stimulating hormone. Hal ini menyebabkan seorang wanita akan mengalami infertilitas selama kurang lebih 6 bulan dan dapat dijadikan sebagai metode penundaan kehamilan secara alami yang disebut dengan MAL (Metode Amenorea Laktasi).

b. Manfaat atau keuntungan pemberian ASI eksklusif juga berpengaruh terhadap kesehatan bayi, antara lain :

1) Meningkatkan sistem kekebalan tubuh bayi dan mencegah infeksi

ASI mengandung berbagai komponen imunologi aktif yang dapat melindungi bayi dari kuman, bakteri dan virus, dan mampu menurunkan resiko kematian pada bayi baru lahir. ASI juga mengandung faktor kekebalan 
tubuh yang berkontribusi dalam menurunkan kejadian gastroenteritis, neonatal necrotizing enterocolitis, lymphoma, penyakit crohn"s, penyakit celiac, dan obesitas selama masa anak-anak. Hasil penelitian yang dilakukan oleh Bachrach,2003 dan Hanson \& Korotkova, 2002 Vidayati (2014) menunjukkan bahwa pemberian ASI bagi bayi dapat menghasilkan antibodi spesifik sebagai kekebalan yang termediasi oleh sel sehingga dapat membantu melindungi bayi dari penyakit otitis media, penyakit saluran napas misalnya respiratory syncytial virus dan pneumonia.

2) Meningkatkan kecerdasan atau kemampuan kognitif bagi bayi.

Komposisi ASI mengandung nutrient yang terbaik bagi bayi baru lahir. ASI mengandung LC-PUFA yang mempunyai hubungan dengan peningkatan kemampuan kognitif atau kecerdasan pada anak. Berdasarkan penelitian yang dilakukan oleh SanGiovanni et al., 2000 Vidayati (2014) LC-PUFA mengandung docosahexanoid acid (DHA) dan arachinoid acid (AA) yang berhubungan dengan visual acuity dan kemampuan kognitif pada anak.

3) Mencegah terjadinya konstipasi

Komponen protein yang terdapat dalam ASI antara lain Whey (lactalbumin) dan kasein dengan perbandingan 60 : 40 pada ASI yang matur. Rasio perbandingan komposisi kedua bahan tersebut merupakan komposisi yang ideal dalam proses pencernaan bayi baru lahir karena mudah dicerna, menyebabkan konsistensi feses yang lunak, dan menimbulkan efek laksatif sehingga mencegah terjadinya konstipasi pada bayi baru lahir.

4) Memberikan stimulasi, rangsangan dan pendidikan Asuhan kebidanan III (Nifas) 170 
bagi bayi

Proses menyusui bukan merupakan proses yang pasif ketika seorang ibu memberikan ASI kepada bayinya. Menyusui tidak hanya untuk memenuhi kebutuhan nutrisi bayi, namun juga merupakan interaksi antara ibu dengan bayinya. Proses menyusui akan merangsang indera penglihatan, pendengaran, penciuman, rasa, dan stimulasi taktil. Saat menyusui ibu dianjurkan untuk mengajak anak berkomunikasi, bernyanyi, dan melakukan interaksi secara aktif. Hal ini akan merangsang perkembangan otak kanan dan otak kiri bayi yang disusui oleh ibunya.

5) Mencegah obesitas pada bayi

Komposisi nutrien ASI sangat kompleks dan ASI merupakan nutrisi yang optimal bagi bayi baru lahir sampai 6 bulan dan dapat diteruskan sampai usia 2 tahun. Kandungan glukosa dalam ASI lebih rendah bila dibandingkan dengan kandungan glukosa dalam susu formula. Penelitian yang dilakukan oleh Frye \& Heinrich, 2003 Vidayati (2014) membuktikan bahwa pemberian ASI eksklusif memberikan perlindungan dan mencegah terjadinya obesitas pada anak usia sekolah.

\subsection{Penilaian Produksi ASI}

Produksi ASI merujuk pada volume ASI yang dikeluarkan oleh payudara. ASI yang telah diproduksi tersimpan pada sinus laktiferous. Selanjutnya ASI dikeluarkan dari payudara kemudian dialirkan kepada bayi, banyaknya ASI yang dikeluarkan oleh payudara dan diminum oleh bayi diasumsikan sama dengan produksi ASI.

Proses produksi ASI merupakan dipengaruhi kontrol hormonal, Asuhan kebidanan III (Nifas) 171 
kontrol fisik laktasi, stimulus sensori, dan beberapa faktor yang lainnya seperti yang telah dipaparkan sebelumnya. Penilaian produksi ASI dapat diketahui berdasarkan beberapa kriteria sebagai acuan untuk mengetahui kecukupan produksi ASI. Indikator yang dapat digunakan sebagai parameter kecukupan produksi ASI di lihat melalui berapa banyak ASI yang dikonsumsi oleh bayi.

a. Bayi usia 0-6 bulan, dapat dinilai mendapat kecukupan ASI bila mencapai keadaan sebagai berikut :

1) Bayi minum ASI tiap 2-3 jam dalam 24 jam minimal mendapatkan ASI 8 kali pada 2-3 minggu pertama.

2) Kotoran berwarna kuning dengan frekuensi sering dan warna menjadi lebih muda pada hari kelima setelah lahir.

3) Bayi akan buang air kecil (BAK) paling tidak 6-8kali perhari

4) Ibu dapat mendengarkan pada saat bayi menelan ASI.

5) Payudara terasa lebih lembek, yang menandakan ASI telah habis

6) Warna bayi merah (tidak kuning) dan kulit terasa kenyal.

7) Pertumbuhan berat badan (BB) dan tinggi badan (TB) bayi sesuai dengan grafik pertumbuhan.

8) Perkembangan motorik baik ( bayi aktif dan motoriknya sesuai dengan rentang usianya)

b. Tanda bayi cukup ASI

1) Bayi kelihatan puas, swaktu-waktu saat lapar akan bangun dan tidur dengan cukup.

2) Bayi menyusu dengan kuat (rakus), kemudian ngantuk dan tertidur pulas. 


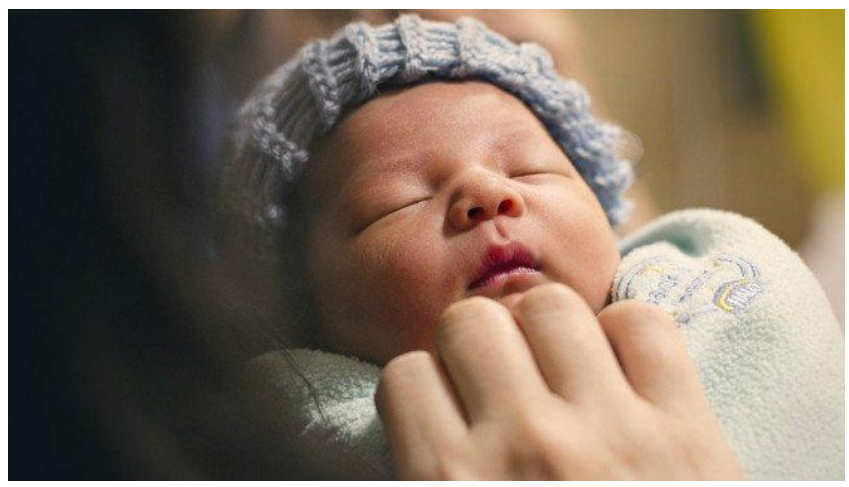

Gambar 10.4 Bayi Tertidur Pulas Setelah Menyusu

c. Berdasarkan WHO dan UNICEF (2011), terdapat tanda kecukupan produksi ASI. Indikator utama atau tanda reliabel produksi ASI yang kurang antara lain :

1) Pertambahan berat badan kurang :

- Bayi baru lahir kehilangan berat badan lebih dari 10 $\%$ pada usia 1 minggu pasca kelahiran atau

- Berat badan bayi kurang dari berat lahir bayi pada usia 2 minggu

2) Mengeluarkan air seni pekat dalam jumlah sedikit (frekuensi berkemih kurang dari 6 kali dalam 24 jam pada usia 6 hari pasca kelahiran). Bayi dengan usia kurang dari 6 hari dapat menggunakan indikator : Bayi dengan usia 3 hari pasca kelahiran maka frekuensi berkemih minimal 3 kali, usia 4 hari frekuensi berkemih minimal 4 kali dan pada hari kelima pasca kelahiran frekuensi berkemih minimal 5 kali per hari. Sebelum usia 4 minggu bayi akan memekatkan urine lebih sedikit, bahkan pada saat dehidrasi sehingga untuk usia bayi kurang dari 4 minggu, urine yang pekat tidak dapat dijadikan sebagai acuan 
untuk pengukuran atau indikator pasti kecukupan produksi ASI. Reece \& Hobbins (2007) juga menyatakan bahwa setelah hari ketiga usia bayi, bayi yang menyusu secara eksklusif biasanya akan berkemih lebih dari 6 kali dalam 24 jam dan buang air besar tiga kali atau lebih dalam 24 jam.

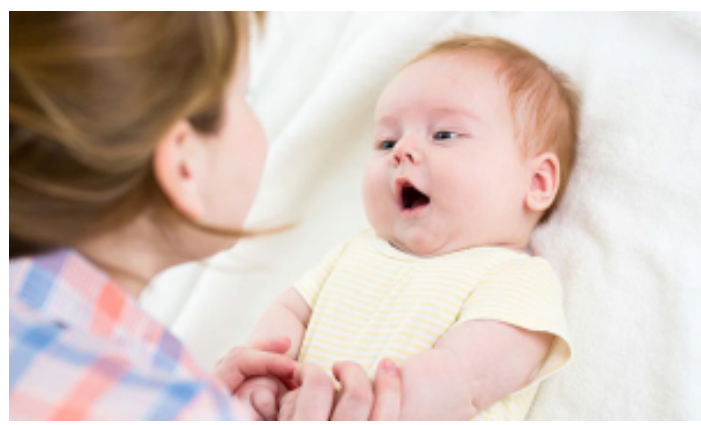

Gamabar 10.5 bayi dengan motoric baik oleh kecukupan ASI

\subsection{Upaya memperbanyak ASI}

ASI adalah cairan kehidupan terbaik yang sangat dibutuhkan oleh bayi. ASI mengandung berbagai zat penting untuk tumbuh kembang bayi. Meski demikian tidak semua ibu mau menyusui banyinya karena berbagai alasan, sebagai contoh : takut gemuk, sibuk, payudara kendor, dan sebagainya. Biasanya ASI tidak mau keluar atau produksinya tidak lancar.

Produksi dan pengeluaran ASI dipengaruhi oleh dua hormone, yaitu prolaktin dan oksitosin. Prolaktin berperan dalam jumlah produksi ASI, sedangkan oksitosin dapat mempengaruhi proses pengeluaran ASI. Prolaktin berkaitan dengan nutrisi ibu, semakin nutrisi yang dikonsumsi baik maka produksi ASI yang dikeluarkan juga banyak. Namun demikian untuk mengeluarkan ASI diperlukan hormon oksitosin yang kerjanya dipengaruhi oleh hisapan bayi. Semakin sering puting susu di hisap oleh bayi maka akan semakin banyak pula 
pengeluaran ASI. Hormon oksitosin sering disebut dengan hormone kasih sayang. Hal ini disebabkan karena kadarnya sangat dipengaruhi oleh suasana hati, rasa bahagia, rasa dicintai, rasa aman, ketenangan dan rasa nyaman.

Beberapa hal yang mempengaruhi produksi ASI adalah sebagai berikut :

1) Makanan

Makanan yang dikonsumsi ibu menyusui sangat berpengaruh terhadap produksi ASI. Apabila makanan yang ibu makan mengandung cukup gizi dan pola makan yang teratur, maka produksi ASI akan akan berjalan dengan lancar

2) Ketenangan jiwa dan pikiran

Untuk memproduksi ASI yang baik, maka kondisi kejiwaan dan pikiran harus tenang. Keadaan psikologis ibu yang tertekan, sedih dan tegang akan menurunkan jumlah produksi ASI.

3) Penggunaan alat kontrasepsi

Penggunaan alat kontrasepsi pada ibu menyusui, perlu diperhatikan agar tidak mengurangi jumlah produksi ASI. Contoh alat kontrasepsi yang di gunakan adalah : kondom, IUD, pil khusus menyusui, atau suntik hormonal 3 bulanan

4) Perawatan payudara

Perawatan payudara bermanfaat merangsang payudara sehingga mempengaruhi hipofisis untuk mengeluarkan hormone prolaktin dan oksitosin

5) Anatomi payudara

Jumlah lobus dalam payudara juga mempengaruhi produksi ASI. Selain itu, perlu diperhatikan juga bentuk anatomi papilla mammae atau putting susu ibu.

6) Faktor fisiologis

ASI terbentuk oleh karena pengaruh hormon prolaktin yang menentukan produksi dan mempertahankan sekresi air susu. 
7) Pola istirahat

Faktor istirahat mempengaruhi produksi dan pengeluaran ASI, apabila kondisi ibu terlalu capek, kurang istirahat, maka produksi ASI juga dapat berkurang.

8) Faktor hisapan anak atau frekuensi penyusuan

Semakin sering bayi menyusu pada payudara ibu, maka produksi dan pengeluaran ASI akan semain banyak. Akan tetapi, frekuensi pemberian ASI pada bayi premature dan bayi lahir cukup bulan berbeda. Studi mengatakan bahwa pada produksi ASI pada bayi premature akan optimal jika dibantu dengan ASI perah lebih dari 5 kali per hari selama bulan pertama setelah melahirkan. Frekuensi bayi menyusu ini berkaitan dengan dengan kemampuan stimulasi hormone dalam kelenjar payudara.

9) Berat bayi lahir.

Barat bayi lahir rendah (BBLR) mempunyai kemampuan menghisap ASI yang lebih rendah dibanding bayi dengan berat lahir normal (>2500gr). Kemampuan menghisap ASI yang lebih rendah ini meliputi frekuensi dan lama penyusuan yang lebih rendah dibanding bayi berat lahir normal yang akan mempengaruhi stimulasi hormon prolaktin dan oksitosin dalam memproduksi ASI.

10) Umur kehamilan saat melahirkan

Umur kehamilan dan berat lahir mempengaruhi produksi ASI. Hal ini disebabkan bayi yang lahir premature (umur kehamilan kurang dari 34 minggu) sangat lemah dan tidak mampu menghisap secara efektif sehingga produksi ASI lebih rendah daripada bayi yang lahir cukup bulan. Lemahnya kemampuan menghisap pada bayi prematur dapat disebabkan berat badan yang rendah dan belum sempurnanya fungsi organ.

11) Konsumsi rokok dan alkohol 
Merokok dapat mengurangi volume ASI karena akan mengganggu hormon prolaktin dan oksitosin dalam produksi ASI. Merokok dapat menstimulasi pelepasan adrenalin dimana adrenalin akan menghambat pelepasan oksitosin. Meskipun minuman alkohol dosis rendah di satu sisi dapat membuat ibu merasa lebih relaks sehingga membantu proses pengeluaran ASI, namun disisi lain etanol dapat menghambat produksi ASI

Beberapa keadaan yang dianggap dapat meningkatkan produksi hormon oksitosin :

- Curahan kasih sayang terhadap bayinya akan memicu ketenangan dan kenyamanan.

- Celotehan atau tangisan bayi yang dapat merubah mood menjadi lebih baik

- Dukungan ayah dalam pengasuhan bayi, seperti menggendong bayi saat akan disusui atau disendawakan, mengganti popok dan memandikan bayi, bermain, hingga membantu pekerjaan rumah tangga, hal tersebut membuat ibu bahagia sehingga dapat memicu keluarnya oksitosin.

- Membelai bayi, memijat bayi, atau memeluk bayi

- Pijat punggung pada costa 5-6 selama 15 menit akan membuat ibu terasa nyaman

- Inhalasi aromateraphi lavender selama 30 menit dapat merangsang keluarnya oksitosin

Beberapa keadaan yang dapat mengurangi produksi hormon oksitosin dapat memicu stress bagi ibu sehingga dapat menghambat kluarnya hormone oksitosin

- Rasa cemas, sedih, marah, kesal, atau bingung 
- Rasa cemas terhadap perubahan bentuk pada payudara dan bentuk tubuhnya, meniggalkan bayi karena harus bekerja dan ASI tidak mencukupi kebutuhan bayi.

- $\quad$ Rasa sakit terutama saat menyusui

\subsection{ASI Eksklusif}

ASI eksklusif (menurut WHO) adalah pemberian ASI saja pada bayi 0 sampai usia 6 bulan tanpa ada tambahan cairan ataupun makanan lain. ASI dapat diberikan sampai bayi berusia 2 tahun. Pemberian ASI eksklusif 0 selama 6 bulan di anjurkan oleh pedoman international yang didasarkan pada bukti ilmiah tentang manfaat ASI baik bagi bayi, ibu, keluarga, maupun Negara.

Menurut penelitian yang dilakukan di Dhaka pada 1.667 bayi selama 12 bulan mengatakan bahwa ASI eksklusif dapat menurunkan resiko kematian akibat infeksi saluran nafas akut dan diare. WHO dan UNICEF merekomendasikan kepada para ibu bila memungkinkan untuk memberikan ASI menerapkan hal-hal sebagai berikut :

1) Inisiasi menyusu dini selama 1 jam setelah kelahiran bayi

2) ASI eksklusif secara on-demand atau sesuai kebutuhan bayi, setiap hari setiap malam.

3) ASI diberikan tidak menggunakan botol, cangkir maupun dot.

\subsection{Pemberian Asi Bagi Ibu Yang Bekerja Di Luar Rumah}

Pemberikan ASI merupakan suatu kewajiban bagi kita para ibu, tapi tentunya tentunya dengan melibatkan peran para ayah untuk memberikan dukungan kepada ibu agar dapat terus memberikan ASI kepada bayinya, karena banyak sekali ibu yang tidak memberikan ASI secara eksklusif dengan memberikan susu formula terhadap bayinya dengan berbagai alasan diantaranya dikarenakan ibu bekerja, 
pemerian praktis. Padahal dengan ASI sangat penting untuk bagi kesehatan anak, dan dengan ASI ibu bisa hemat.

a. Beberapa tips pemberian ASI sebagai berikut :

1) Perah/pompa ASI setiap 3-4 jam sekali secara teratur. Hal ini perlu dilakukan agar prduksi ASI tetap terjaga.

2) Pilih waktu dimana payudara dalam keadaan yang paling penuh terisi, pada umumnya terjadi di pagi hari.

3) Semua peralatan yang akan di gunakan telah di sterilkan terlebih dahulu. Breast pump sebaiknya dibersuhkan setelah digunakan agar sisa susu tidak mongering dan menjadi sulit dibersihkan.

4) Pilih tempat yang tenang dan nyaman pada saat memerah susu, tempat yang ideal dimana ibu tidak terganggu suara bel pintu atau telepon masuk. Di tempat kerja, mungkin bisa di ruang rapat yang kosong, dll.

5) Cuci tangan dengan sabun, sedangkan payudara dibersihkan dengan air.

6) Sebelum memulai, minumlah segelas air atau cairan lainnya, misalnya susu, juice, atau sup. Di sarankan minuman hangat agar membantu menstimulasi payudara.

7) Saat memrah ASI, ibu harus dalam kondisi santai. Kondisi psikologis ibu menyusui sangat menentukan keberhasilan ASI eksklusif. Menurut hasil penelitian $>80 \%$ kegagalan ibu menyusui dalam memberikan ASI eksklusif adalah faktor psikologis ibu menyusui. Saat ibu memeras ASI, jangan tegang dan jangan di targetkan berapa banyak ASI yang harus keluar.

8) Lakukan perawatan payudara : massage/pemijatan payudara, serta kompres air hangat dan dingin bergantian.

9) Jika ada masalah dalam ASI, jangan ragu untuk enghubungi atau konsultasi pada klinik laktasi. 
b. Lama penyimpanan ASI perah :

1) Jika ASI pada suhu ruangan tidak ber AC bertahan 4 jam. Jika ruangan ber AC bisa sampai 6 jam. Suhu ruangan ber AC tersebut harus stabil, misalnya AC tidak mati sama sekali selama botol ASI ada di dalamnya.

2) Jika segera disimpan di lemari es, ASI ini bisa bertahan sampai 8 hari dalam suhu lemari es. Syaratnya, ASI ditempatkan dalam ruangan terpisah dari bahan makanan lain.

3) Jika lemari es tidak memiliki ruangan terpisah untuk penyimpanan botol ASI hasil pompa, maka sebaiknya ASI jangan disimpan lebih dari 3×24 jam.

4) Dapat juga membuat ruangan terpisah dengan cara menempatkan botol ASI dalam container plastik yang tentunya dibersihkan terlebih dahulu.

5) ASI hasil pompa dapat disimpan dengan aman pada suhu kamar maksimum $25^{\circ} \mathrm{C}$ selama 4 jam, dalam lemari es pada suhu $4^{\circ} \mathrm{C}$ dapat disimpan selama 72 jam, dalam pembeku atau frezzer pada suhu $-20^{\circ} \mathrm{C}$ selama $3-6$ bulan.

6) Jangan lupa untuk selalu mencantumkan jam, hari, tanggal dilakukan pemerahan ASI pada botol susu. 


\begin{tabular}{|c|c|c|c|}
\hline ASI & Suhu Ruangan & Lemari Es / Kulkas & Freezer \\
\hline $\begin{array}{l}\text { ASI yang baru saja } \\
\text { diperah (ASI } \\
\text { segar) }\end{array}$ & $\begin{array}{l}\text { ASI matang: } \\
24 \text { jam dalam suhu } \\
15^{\circ} \mathrm{C} \\
10 \text { jam dalam suhu } \\
19-22^{\circ} \mathrm{C} \\
4-6 \text { jam dalam suhu } \\
25^{\circ} \mathrm{C}\end{array}$ & $\begin{array}{l}\text { 3-8 hari dengan suhu 0- } \\
4{ }^{\circ} \mathrm{C} . \\
\text { Jangan simpan di bagian } \\
\text { pintu, tetapi simpan di } \\
\text { bagian paling belakang } \\
\text { lemari es/kulkas - paling } \\
\text { dingin dan tidak terlalu } \\
\text { terpengaruh perubahan } \\
\text { suhu }\end{array}$ & $\begin{array}{l}\text { 3-4 bulan dalam } \\
\text { freezer } 2 \text { pintu. } \\
\\
6-12 \text { bulan dalam } \\
\text { freezer khusus } \\
\text { yang sangat } \\
\text { dingin }\left(<18^{\circ} \mathrm{C}\right)\end{array}$ \\
\hline \begin{tabular}{|l} 
ASIP beku- \\
dicairkan dalam \\
lemari es/kulkas \\
tapi belum \\
dihangatkan \\
\end{tabular} & $\begin{array}{l}\text { Tidak lebih dari } 4 \\
\text { jam(yaitu jadwal } \\
\text { minum ASIP } \\
\text { berikutnya) }\end{array}$ & $\begin{array}{l}\text { Simpan di dalam lemari } \\
\text { es/kulkas sampai dengan } 24 \\
\text { jam }\end{array}$ & $\begin{array}{l}\text { JANGAN } \\
\text { masukkan } \\
\text { kembali dalam } \\
\text { freezer }\end{array}$ \\
\hline $\begin{array}{l}\text { ASIP yang sudah } \\
\text { dicairkan dengan } \\
\text { air hangat }\end{array}$ & $\begin{array}{l}\text { Untuk diminum } \\
\text { sekaligus }\end{array}$ & $\begin{array}{l}\text { Dapat disimpan selama } 4 \\
\text { jam atau sampai jadwal } \\
\text { minum ASIP berikutnya }\end{array}$ & \begin{tabular}{|l} 
JANGAN \\
masukkan \\
kembali dalam \\
freezer
\end{tabular} \\
\hline $\begin{array}{l}\text { ASIP yang sudah } \\
\text { mulai diminum } \\
\text { oleh bayi dari } \\
\text { botol yang sama }\end{array}$ & $\begin{array}{l}\text { Sisa yang tidak } \\
\text { dihabiskan harus } \\
\text { dibuang }\end{array}$ & Dibuang & Dibuang \\
\hline
\end{tabular}

Gambar 9.6 : Table penyimpanan ASI

c. Cara menyimpan ASI hasil pompa atau perasan sebagai berikut

1) Simpan ASI dalam botol yang telah disterilkan terlebih dahulu (direbus, di kukus, atau bisa juga dengan memanaskannya dengan oven).

2) Tempat penyimpanan ASI sebetulnya adalah botol yang terbuat dari gelas atau kaca.

3) Jika terpaksa menggunakan botol atau plastik, pastikan plastiknya cukup kuat ( tidak meleleh jika direndam dengan air panas).

4) Jangan pakai botol susu yang berwarna atau bergambar karena kemungkinan catnya bisa meleleh jika terkena panas. 
5) Jangan lupa bubuhkan label setiap kali ibu menyiman botol ASI, dengan mencantumkan tanggal dan jam ASI dipompa atau diperas.

6) Simpan ASI didalam botol yang tertutup rapat, jangan di tutup dengan dot karena masih ada peluang untuk berinteraksi dengan udara.

7) Jika dalam 1 hari ibu memompa atau memeras ASI bebarapa kali, bisa saja ASI tersebut digabungkan dalam botol yang sama. Syaratnya suhu tempat botol di simpan stabil, antara $0-15^{\circ} \mathrm{C}$.

8) Penggabungan hasil simpananini bisa dilakukan asalkan jangka waktu pemompaan/pemerasan pertama dan terakhir tidak lebih dari 24 jam.

9) ASI dapat disimpan dalam botol/plastic, termasuk plastik klip $\pm 80-100$ cc.

10) ASI yang disimpan dalam freezer dan sudah dikeluarkan sebaikanya tidak digunakan lagi setelah 2 hari.

11) ASI beku perlu di cairkan terlebih dahulu dalam lemari es $4^{0} \mathrm{C}$.

12) Asi beku tidak boleh dimasak/dipanaskan, hanya boleh dihangatkan dengan merendam dalam air hangat

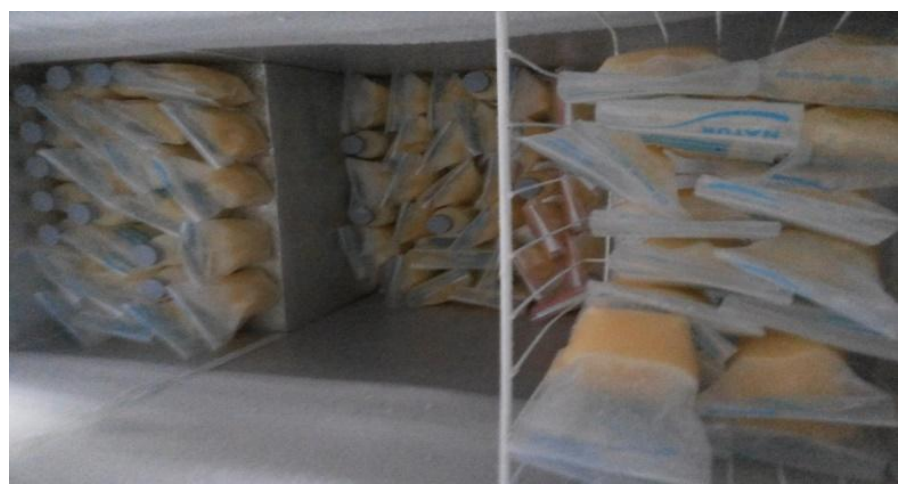

Gamabr 9.7 : Penyimpanan ASI 
d. Cara memberikan ASI yang sudah didinginkan pada bayi :

1) Panaskan ASI dengan cara membiarkan botol dialiri air panas yang bukan mendidih yang keluar dari keran atau merendam botol didalam baskom atau mangkuk yang berisi air panas atau bukan mendidih.

2) Jangan sekali-kali memanaskan botol dengan cara mendidihkannya dalam panic, menggunakan microwave atau alat pemanas lainnya, kecuali yang memang di desain untuk memanaskan botol berisi simpanan ASI

3) Ibu tentunya mengetahui berapa banyak ASI yang biasanya diminum oleh bayi ibu. Sesuaikanlah jumlah susu yang dipanaskan dengan kebiasaan tersebut. Misalnya : dalam satu botol ibu menyimpan sebanyak 180 cc ASI, tetapi bayi ibu biasanya hanya meminum $80 \mathrm{cc}$, jangan langsung dipanaskan semua karena susu yang telah dipanaskan tidak dapat disimpan kembali.

Jika mengikuti pedoman/perahan ASI dan penyimpanan yang baik, ASI tidak mungkin basi. Terkadang memang setelah disimpan atau didinginkan dapat terjadi perubahan warna dan rasa, tetapi hal tersebut menandakan bahwa ASI sudah basi. Kemungkinan yang terjadi adalah berkurangnya khasiat ASI, terutama zat yang membantu pembentukan daya imun bayi. Tidak sulit untuk memberikan ASI eksklusif selama 6 bulan kepada bayi anda. Waktu 6 bulan hanya sebentar, setelah itu barulah bayi diberikan makanan pendamping ASI (MP-ASI). Jadi mulailah dari sekarang untuk memberikan bayi anda ASI seacra eksklusif karena ASI merupakan investasi bagi pertumbuhan bayi. 


\subsection{Perawatan Payudara}

Perawatan payudara dilakukan atas berbagai indikasi, antara lain puting tidak menonjol atau bendungan payudara. Tujuannya adalah memperlancar pengeluaran ASI saat masa menyusui. untuk pasca persalinan, laukan sedini mungkin yaitu 1 sampai 2 hari dan dilakukan 2 kali sehari, berikut langkah-langkah perawatan payudaran :

a. Langkah-langkah perawatan payudara adalah sebagai berikut :

1) Pengompresan

Kompres payudara dengan handuk kecil hangat selama 2 menit, lalu ganti kompres dengan air dingin. Kompres bergantian selama 3 kali dan di akhiri dengan kompres air hangat.

2) Pengurutan pertama.

Licinkan kedua telapak tangan dengan minyak. Tempatkan kedua tangan diantara payudara. Pengurutan dilakukan dimulai kearah atas, lalu telapak tangan kanan kearah sisi kiri dan telapak tangan kiri kea rah sisi kanan. Lakukan terus pengurutan kearah bawah samping, selanjutnya pengurutan melintang. Ulangi masing-masing 20-30 gerakan untuk tiap payudara 

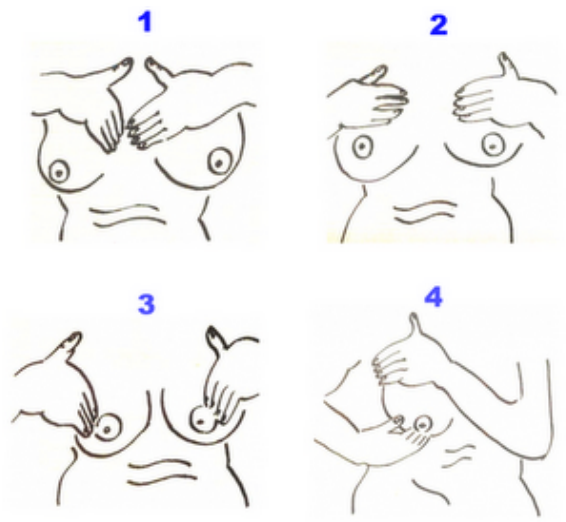

Gambar 10.8 cara pengurutan payudara

3) Pengurutan kedua

Sokong payudara kiri dengan tangan kiri, kemudian dua atau tiga jari tangan kanan membuat gerakan memutar sambil menekan mulai dari pangkal payudara dan berakhir pada putting susu. Lakukan 2 gerakan setiap payudara secara bergantian.

4) Pengurutan ketiga

sokong payudara kiri dengan satu tangan, sedangkan tangan lainnya mengurut dengan sisi kelingking dari arah tepi ke arah putting susu. Lakukan skitar 30 kali

5) Pengosongan ASI

Pengosongan ini dimaksudkan untuk mencegah terjadinya bendungan ASI, caranya keluarkan ASI dengan meletakkan ibu jari dan telunjuk kira-kira 2 sampai $3 \mathrm{~cm}$ dari putting susu dan tamping ASI yang telah di keluarkan. Tekan payudara kearah dada dan perhatikan agar jari-jari jangan di regangkan. Angkat payudara yang agak besar untuk menekan dan mengosongkan tempat penampungan susu pada 
payudara tanpa rasa sakit. Ulamgi untuk masing-masing payudara.

b. Berikut ini adalah tips untuk perawatan payudara:

1) Kenakan bra untuk menjaga bentuk payudara tetap indah. Pilih ukuran bra yang sesuai agar dapat menopang payudara dengan baik.

2) Bersihkan secara rutin daerah seputar putting susu dengan kapas yang telah dibasahi dengan air hangat.

3) Oleskan minyak (olive oil, VCO, atau baby oil) pada payudara untuk menjaga kelembapan. Agar hasilnya lebih maksimal, lakukan pijatan ringan dengan gerakan lembut. Lakukan senam ringan dengan focus untuk memperkuat otot dada.

\subsection{Cara Menyusui Yang Benar}

Pengertian teknik menyusui yang benar adalah cara memberikan ASI kepada bayi dengan perlekatan dan posisi ibu dan bayi yang benar.

1) Pembentukan dan persiapan ASI

Persiapan memberikan ASI dilakukan bersamaan dengan kehamilan. Pada kehamilan, payudara semakin padat karena retensi air, lemak, serta berkembangnya kelenjar-kelenjar payudara yang dirasakan tegang dan sakit. Bersamaan dengan membesarnya kehamilan, perkembangan dan persiapan untuk pemberian ASI semakin tampak. Payudara makin besar, putting susu semakin menonjol, pembuluh darah semakin tanpak, dan areola mamae semakin menghitam.

2) Persiapan memperlancar pengeluaran ASI dilaksanakan dengan jalan sebagai berikut 
a. Membersihkan putting susu dengan air atau minyak sehingga epitel yang lepas tidak menumpuk.

b. Putting susu ditarik-tarik setiap mandi sehingga menonjol untuk memudahkan bayi menghisap.

c. Bila putting susu belum menonjol ibu dapat memakai pompa ASI atau bisa dengan jalan operasi.

3) Posisi dan perlekatan menyusui

Hal terpenting dalam posisi menyusui adalah ibu merasa nyaman dan rileks. Terdapat berbagai macam posisi menyusui. Cara menyusui yang tergolong biasa dilakukan adalah dengan duduk, berdiri, atau berbaring.

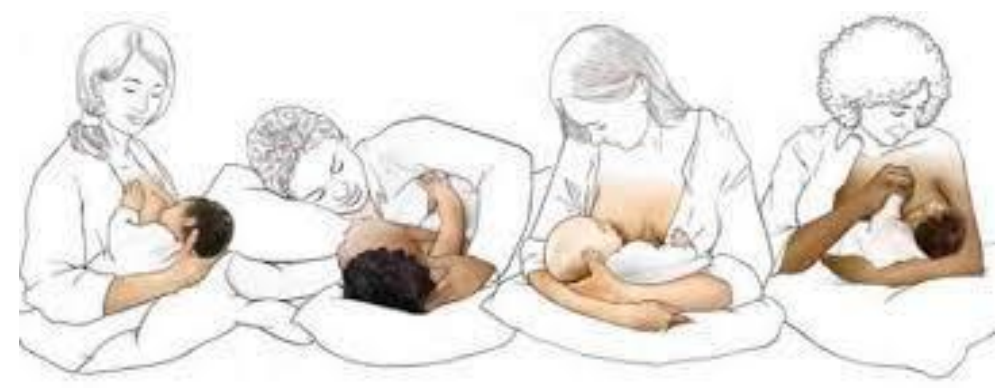

Gambar 10.9 : Posisi menyusui

4) Beberapa langkah-langkah menyusui yang benar adalah sebagai berikut :

- Cuci tangan yang bersih dengan sabun, perah sedikit ASI dan oleskan di sekitar putting, duduk dan berbaring dengan santai

- Ibu harus mencari posisi nyaman, biasanya duduk tegak di tempat tidur/kursi ibu merasa relaks

- Lengan ibu menopang kepala, leher, dan seluruh badan bayi (kepala dan tubuh berada dalam garis lurus), muka bayi menghadap ke payudara ibu, hidung 
bayi di depan putting susu ibu. Posisi bayi menghadap ibu, kepalanya harus sejajar dengan tubuhnya, tidak melengkung ke belakang/menyamping, telinga, bahu, dan panggul bayi berada dalam satu garis lurus.

- Ibu mendekatkan bayi ke tubuhnya (muka bayi ke payudara ibu) dan mengamati bayi yang siap menyusu : membuka mulut, bergerak mencari, dan menoleh. Bayi harus dekat dengan payudara ibu. Ibu tidak harus mencondongkan badan dan bayi tidak meregangkan lehernya untuk mencapai putting susu ibu.

- Ibu menyentuhkan putting susunya ke bibir bayi, menunggu hingga mulut bayi terbuka lebar kemudian mengarahkan mulut bayi ke puting susu ibu hingga bibir bayi dapat menangkap puting susu ibu tersebut. Ibu memegang payudara dengan satu tangan dengan cara menempatkan empat jari tangan di bawah payudara, dan ibu jari diatas payudara. Ibu jari dan telunjuk harus membentuk huruf $\mathrm{C}$, semua jari ibu tidak boleh terlalu dekat dengan areola.

- Pastikan bahwa sebagian besar areola masuk kedalam mulut bayi. Dagu rapat ke paydara ibu dan hidungnya menyentuh bagian atas payudara. Bibir bawah bayi melengkung keluar.

- Bayi diletakkan mengahadap ke ibu dengan posisi sanggah seluruh tubuh bayi jangan hanya leher dan bahunya saja, kepala dan tubuh bayi harus lurus, hadapkan bayi ke dada ibu sehingga hidung bayi berhadapan dengan putting susu, dekatkan dada bayi ke badan ibu, menyentuh bibir bayi ke putting susunya dan menunggu sampai mulut bayi terbuka lebar. 
- Jika bayi sudah selesai menyusui, ibu mengeluarkan putting dari mulut bayi dengan cara memasukkan jari kelingking ibu diantara mulut dan payudara

- Menyendawakan bayi dengan menyandarkan bayi di pundak atau menelungkupkan bayi melintang kemudian menepuk-nepuk punggung bayi.

- Gambar perlekatan mulut bayi saat menyusu benar dan ssalah, setelah menyusui

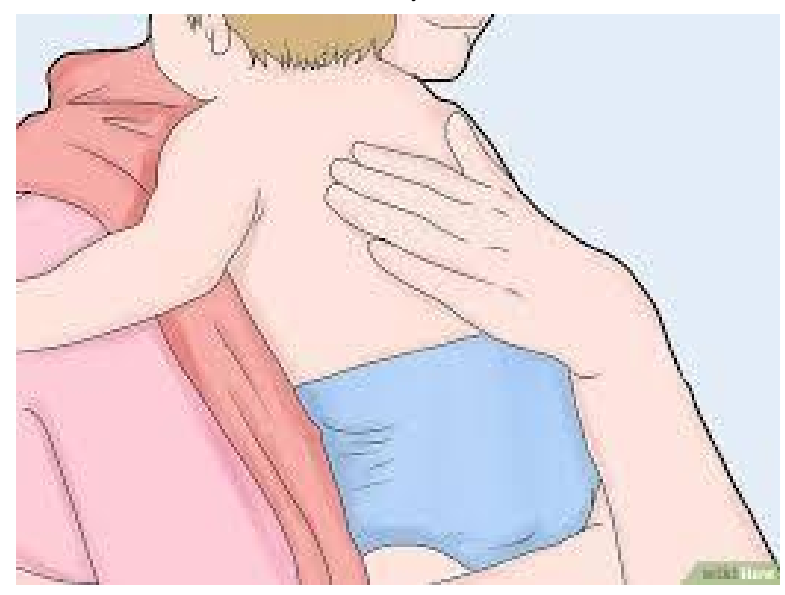

Gambar 10.10 : cara menyendawakan

5) Cara pengamatan teknik menyusi yang benar

Menyusui dengan teknik yang tidak benar dapat mengakibatkan putting susu menjadi lecet dan ASI tidak kluar secara optimal sehingga mempengaruhi produksi ASI selanjutnya atau bayi enggan menyusu. Apabila bayi telah menyusui dengan benar, maka akan memperlihatkan tanda-tanda sebagai berikut :

- Bayi tampak tenang

- Badan bayi menempel pada payudara ibu 
- Mulut bayi terbuka lebar

- Dagu bayi menempel pada payudara ibu

- Sebagian areola masuk kedalam mulut bayi, areola bawah lebih banyak yang masuk.

- Hidung bayi mendekati dan kadang-kadang menyentuh payudara ibu.

- Mulut bayi mencakup sebanyak mungkin areola (tidak hanya putting saja). Lingkar areola atas terlihat lebih banyak bila dibandingkan dengan areola bawah.

- Lidah bayi menopang putting dan areola bagian bawah.

- Bibir bawah bayi melengkung keluar

- Bayi tampak menghisap kuat dengan irama perlahan.

- Putting susu tidak terasa nyeri

- Telinga dan lengan bayi terletak pada satu garis lurus

- Kepala bayi agak menengadah.

- Bayi menghisap kuat dan dalam secara perlahan dan kadang disertai dengan berhenti sesaat.

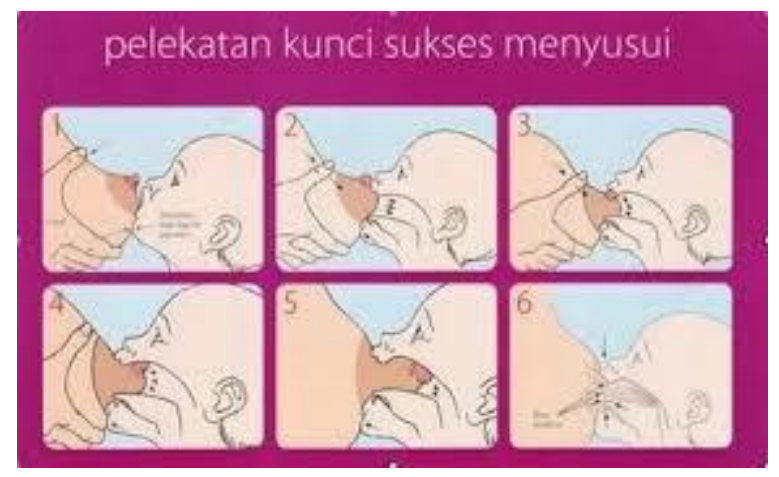

Gambar 10.11 : teknik menyusui yang benar

6) Lama dan frekuensi menyusui 
Sebaiknya tindakan menyusui bayi dilakukan di setiap bayi membutuhkan karena bayi akan menentukan sendiri kebutuhannya. Ibu harus menyusui bayinya jika menangis bukan karena penyebab lain (BAK, kepanasan/kedinginan, atau sekedar ingin didekap) atau ibu sudah merasa perlu menyusui bayina. Bayi yang sehat dapat mengosongkan payudara sekitar 5-7 menit dan ASI dalam lambung akan kosong dalam waktu 2 jam. Pada awalnya, memiliki pola yang teratur dalam menyusui dan akan mempunyai pola tertentu setelah 1-2 minggu kemudian.

Menyusui yang di jadwal akan berakibat kurang baik karena hisapan bayi sangat berpengaruh pada rangsangan produksi ASI selanjutnya. Dengan menyusui tanpa jadwal dan sesuai kebutuhan bayi, akan mencegah timbulnya masalah menyusui. Ibu yang bekerja dianjurkan agar lebih sering menyusi di malam hari. Bila sering disusukan pada malam hari akan memicu produksi ASI. Untuk menjaga keseimbangan ukuran kedua payudara, maka sebaiknya setiap kali menyusui, harus dengan kedua payudara. Pesankan kepada ibu agar berusaha menyusui sampai payudara terasa kosong, agar produksi ASI menjadi lebih baik. Setiap kali menyusui, di mulai dengan payudara yang terakhir di susukan. Selama masa menyusui sebaiknya ibu menggunakan bra (kutang) yang dapat menyangga payudara, tetapi tidak terlalu ketat.

\subsection{Masalah dalam Pemberian ASI}

Kegagalan dalam proses menyusui sering disebabkan karena timbulnya beberapa masalah, baik masalah pada ibu maupun pada bayi. Pada sebagian ibu tidak memahami masalah ini, kegagalan masalah menyusui sering dianggap masalah pada anak saja. 
Masalah dari ibu yang timbul selama menyusui dapat di mulai sejak sebelum persalinan (periode antenatal), pada masa pasca persalianan dini dan masa pasca persalinan lanjut. Masalah pada bayi umumnya berkaitan dengan menejemen laktasi sehingga bayi sering menjadi 'bingung puting' atau sering menangis, yang sering diinterpretasikan oleh ibu dan keluarga bahwa ASI saja tidak tepat untuk bayinya.

Masalah menyusui dapat pula diakibatkan karena keadaan khusus. Selain itu, ibu sering kali mengelukan bayinya sering menangis, 'menolak' menyusu, dan sebagainya yang sering diartikan bahwa ASI tidak cukup, atau ASI tidak enak, tidak baik, atau apapun pendapatnya sehingga sering menyebabkan diambilnya keputusan untuk menghentikan pemberian ASI. Berikut ini beberapa hal yang dapat menimbulkan masalah dalam pemberian ASI :

a. Salah informasi

1) Banyak ibu yang merasa bahwa susu formula sama baiknya atau bahkan lebih baik dari ASI sehingga cepat menambah susu formula bila merasa ASI kurang. Petugas kesehatan juga masih banyak yang tidak memberikan informasi pada saat pemeriksaan kehamilan atau saat memulangkan bayi. Sebagai contoh, banyak ibu/petugas kesehatan yang tidak mengetahui hal-hal berikut.

2) Bayi pada minggu-minggu pertama defekasinya encer dan sering sehingga dikatakan diare, dan sering juga petugas kesehatan menyarankan untuk menghentikan proses menyusui. Padahal sifat defekasi bayi yang mendapat kolostrum memang demikian karena kolostrum memang demikian bersifat sebagai laksan (zat pencahar).

3) ASI baelum keluar pada hari pertama sehingga bayi perlu diberikan susu formula atau minuman lain. Padahal bayi yang baru lahir cukup bulan dan sehat mempunyai Asuhan kebidanan III (Nifas) 192 
persediaan kalori dan cairan yang dapat membuatnya bertahan hingga 48 jam bahkan ada beberapa penelitian yang menyatakan 72 jam, namun hal tersebut tidak dapat di samaratakan pada kondisi semua bayi. Asi keluar sedikit pasca persalinan dan dapat mencukupi kebutuhan bayi baru lahir, jumlah ASI akan semakin banyak jika terus diberikan dan sehingga dapat menyesuaikan kebutuhan bayi.

4) Payudara berukuran kecil dianggap kurang menghasilkan ASI padahal ukuran payuadara tidak menentukan apakah produksi ASI cukup atau kurang karena ukuran ditentukan oleh banyaknya lemak pada payudara. Sedangkan kelenjar penghasil ASI sama banyaknya walaupun payudara kecil dan produksi ASI dapat tetap mencukupi apabila menejemen laktasi dilaksanakan dengan baik dan benar.

5) Informasi yang perlu diberikan kepada ibu hamil/menyusui antara lain meliputi hal-hal sebagai berikut.

- Fisiologi laktasi

- Keuntungan pemberian ASI

- Keuntungan rawat gabung

- Cara menyusui yang baik dan benar

- Kerugian pemberian susu formula

- Menunda pemberian makanan lainnya paling kurang 6 bulan.

b. Puting susu datar atau terbenam

Puting seperti ini sebenarnya masih dapat menyusui bayinya dan upaya selama antenatal umumnya kurang berguna, misalnya dengan memanipulasi Hofman , menarik-narik putting, ataupun pengguna breast shield dan breast shell. Tindakan yang paling efesien untuk memperbaiki keadaan ini adalah hisapan bayi yang kuat secara langsung. Oleh karena itu, sebaiknya tidak dilakukan 
apa-apa , tunggu saja sampai bayi lahir segera setelah lahir lakukan tindakan sebagai berikut :

1) Skin to skin kontak dan biarkan bayi menghisap sedini mungkin

2) Biarkan bayi mencari putting kemudian menghisapnya. Bila perlu coba berbagai posisi untuk mendapat keadaan nyaman dan menguntungkan. Rangsangan putting agar dapat keluar sebelum bayi mengambilnya

3) Apabila putting benar-benar tidak muncul, dapat di Tarik dengan pompa putting susu (nipple puller), atau paling sederhana dengan sedotan spuit yang dipakai terbalik.

4) Jika mengalami kesulitan, usahakan agar bayi tetap di susui dengan sedikit penekanan pada areola mammae dengan jari sehingga terbentuk dot ketika memasukkan putting susu kedalam mulut bayi.

5) Bila terlalu penuh $\mathrm{ASI}$, dapat diperas terlebih dahulu dan diberikan dengan sendok atau cangkir, atau teteskan langsung mulut bayi, bila perlu lakukan ini 1-2 minggu.

c. Putting Susu Lecet (Abraded And Or Cracked Nipple)

Putting susu lecet disebabkan oleh trauma saat menyusui. Selain itu, dapat pula terjadi retak dan pembentukan celah-celah. Retakan pada putting susu dapat sembuh sendiri dalam waktu 48 jam.

1) Beberapa penyebab putting susu lecet adalah sebagai berikut :

- Teknik menyusui yang tidak benar

- Putting susu yang terpapar oleh sabun, krim, alcohol, ataupun zat iritan lain saat ibu membersihkan putting susu. 
- Moniliasis pada mulut bayi yang dapat menular pada putting susu ibu.

- $\quad$ Bayi dengan tali lidah pendek (frenulum lingue).

- Cara menghentikan menyusui yang kurang tepat.

2) Tindakan yang dapat dilakukan untuk mengatasi puting susu lecet yakni :

- Cari penyebab putting susu lecet.

- Selama putting susu diistirahatkan, sebaiknya ASI tetap tetap dikeluarkan dengan tangan, dan tidak dianjurkan dengan mengguanakan alat pompa, karena nyeri atau bayi disusukan lebih dulu pada putting susu yang normal atau lecetnya sedikit.

- Sebelum menyusui keluarkan sdikit ASI dan oleskan pada areola dan putting susu untuk melembabkan putting susu, setelah menyusui olesi kembali puting dengan ASI ( hind milk), tidak menggunakan sabun, krin alcohol, ataupun zat iritan yang lain saat membersihkan payudara.

- Menyusui lebih sering (8-12 kali dalam 24 jam)

- Putting susu yang sakit dapat diistirahatkan untuk sementara waktu kurang lebih 1x24 jam.

- Cuci payudara sekali sehari, jangan menggunakan sabun.

- Posisi menyusui harus benar, bayi menyusu sampai kekalang payudara dan susukan secara bergantian diantara kedua payudara.

- Keluarkan sedikit ASI dan oleskan ke putting susu yang lecet dan biarkan kering.

- Pergunakan bra yang menyangga.

- Bila terasa sangat sakit boleh minum obat pengurang nyeri. 
- Jika penyebabnya monilia, berikan pengobatan dengan menggunakan nystatin.

d. Putting melesak (masuk ke dalam)

Jika putting susu melesak diketahui sejak kehamilan, hendaknya putting susu di Tarik-tarik dengan menggunakan minyak kelapa setiap mandi 2-3 kali sehari. Jika putting susu melesak di ketahi setelah melahirkan dapat dibantu dengan tudung putting (nipple hoot).

e. Payudara bengkak

Perbedaan anatara payudara penuh karena berisi ASI dengan payudara bengkak yakni, jika payudara penuh karena terisi ASI akan terasa berat, panas, dank eras, bila diperiksa ASI keluar dan tidak ada demam. Sedangkan pada payudara bengkak, akan tampak adanya odem, sakit, putting kencang, kulit mengkilap walau tidak merah, dan bila di pencet atau diperiksa ASI tidak keluar, akan muncul demam setelah 24 jam.

Penyebab, payudara bengkak dapat disebabkan karena menyusui yang tidak kontinu. Sehingga sisa ASI yang terkumpul pada daerah duktus. hal ini terjadi karena produksi ASI meningkat tdk seimbang dengan frekuensi menyusui, terlambat menyusukan dini, perlekatan kurang baik, pengeluaran ASI kurang sempurna.

1) Beberapa tindakan yang dapat dilakukan untuk mencegah terjadinya payudara bengkak, antara lain :

- Menyusui bayi segera setelah lahir dengan posisi dan cara menyusui yang benar.

- Menyusui bayi tanpa jadwal (on demand)

- Keluarkan ASI dengan pompa bila produksi ASI melebihi kebutuhan bayi. 
- Jangan memberikan minuman lain pada bayi

- Lakukan perawatan payudara pascapersalinan.

2) Beberapa tindakan untuk mengatasi terjadinya payudara bengkak, yakni :

- Setiap 2 jam sekali sebelum menyusui kompres payudara dengan washlap bersih.

- Kaluarkan ASI sbelum menyusui agar payudara lebih lunak sehingga lebih muda memasukkannya ke dalam mulut bayi.

- Bila bayi belum dapat menyusu, ASI dikeluarkan dengan tangan atau pompa dan dan diberikan pada bayi melalui cangkir menggunakan sendok.

- Tetap mengeluarkan ASI sesering yang diperlukan sampai bendungan teratasi.

- Untuk mengurangi rasa sakit dapat diberikan kompres hangat dan dingin.

- Bila ibu demam dapat diberikan obat penurun panas dan pengurang nyeri.

- Lakukan pemijatan pada daerah payudara yang bengkak, yang dapat bermanfaat untuk memperlancar pengeluaran ASI.

- Pada saat menyusui, sebaiknya ibu tetap releks.

- Makan makanan bergizi untuk meningkatkan daya tahan tubuh serta memperbanyak minum.

- Jika ibu yang sedang menyusui terserang penyakit seperti flu, usahakan untuk tetap memberikan ASI dengan menutup mulut dan hidung dengan masker.

f. Abses payudara (mastitis)

Mastitis merupakan suatu peradangan yang terjadi pada payudara. Payudara menjadi merah, bengkak, terkadang di 
ikuti rasa nyeri dan panas. Serta suhu tubuh meningkat. Pada bagian dalam terasa padat (lump), dan di luarnya kulit berwarna merah. Kejadian ini dapat terjadi pada masa nifas hari ke 1-3 minggu setelah persalinan yang diakibatkan oleh sumbatan saluran ASI yang berlanjut. Keadaan ini bisa diakibatkan karena pengeluaran ASI yang tidak sempurna, hal ini dapat juga terjadi karena kebiasaan menekan payuara dengan jari atau karena tekanan baju/bra, serta pengeluaran ASI yang kurang baik pada payudara yang besar, terutama pada bagian bawah payudara yang menggantung.

Ada dua jenis mastitis, yaitu yang terinfeksi milk statis disebut non-infective mastitis dan yang telah terinfeksi bakteri : infective mastitis. lecet pada putting dan trauma pada kulit juga mengundang infeksi bakteri. Beberapa tindakan yang dapat dilakukan yaitu :

1) Kompres hangat/panas dan pemijatan.

2) Rangsang oksitosin, dimulai pada payudara yang tidak sakit, stimulasi putting, pijat lehet sampai dengan punggung dll.

3) Pemberian antibiotic : flucloxacilin atau erytromicin selama 7-10 hari.

4) Bila perlu bisa diberikan istirahat total dan obat penghilang rasa nyeri.

5) Kalau sudah terjadi abses payudara maka tidak boleh disusukan kepada bayi hingga ASI sudah tidak terkontaminasi dengan push, dan hal tersebut memerlukan tindakan bedah

g. Sindrom ASI kurang 
Pada kenyatannya sering kali ASI tidak benar-benar kurang, tanda-tanda yang mungkin saja produksi ASI kurang anatara lain :

1) Bayi tidak puas setiap setelah menyusui, seringkali menyusu dengan waktu yang sangat lama, akan tetapi terkadang bayi juga lebih cepat menyusu. Akibatnya menimbulkan prasangka produksi ASI berkurang padahal bayi sdh pandai menyusu.

2) Bayi sering menangis atau bayi menolak untuk menyusu.

3) Tinja bayi keras, kering atau berwarna hijau.

4) Payudara tidak membesar selama kehamilan, atau ASI tidak langsung keluar pasca persalinan.

5) Berat badan bayi meningkat kurang dari rata-rata 500gram perbulan.

6) Berat badan bayi tidak naik atau belum kembali dalam waktu 2 minggu

7) Mengompol rata-rata kurang dari 6 kali dalam 24 ajm : cairan urine pekat, bau dan berwarna kuning.

h. Bayi sering menangis

Perhatikan sebab bayi menangis, jangan biarkan bayi menangis terlalu lama, puaskan bayi menyusu. Beberapa penyebab bayi menangis anata lain sebagai berikut :

1) Bayi mearasa tidak nyaman.

2) Bayi merasa skait

3) Bayi basah

4) Bayi kurang gizi

Tindakan yang dapat dilakukan oleh ibu antara lain, ibu tidak tidak perlu cemas karena akan menggagu proses 
laktasi, perbaiki posisi menyusui, periksa pakaian bayi : apakah basah, jangan biarkan bayi menangis terlalu lama.

i. Bayi bingung putting

Nipple confution adalah keadaan yang terjadi karena bayi mendapat susu formula dalam botol berganti-ganti dengan menyusu pada ibu. Terjadi karena mekanisme menyusu pada putting berbeda dengan botol. Tanda-tanda bayi bingung putting antara lain : menghisap putting seperti menghisap dot, menghisap terputus-putus dan sebentar, serta bayi menolak menyusu. Tindakan yang dapat dilakukan antara lain jangan mudah memberi PASI, jika terpaksa berikan dengan menggunakan sendok atau pipet.

j. Bayi premature

Pada bayi premature berikan ASI seserang mungkin, walapun hanya sebentar-sebentar. Rangsang dengan sentuh langit-langit bayi dengan jari ibu yang bersih, , jika tidak dapat menghisap berikan pipa nasogastric, tangan dan sendok, uraian sesuai dengan umur bayi adalah sebagai berikut :

1) Bayi umur kehamilan <30 minggu : $B B L<1.250$ gr. biasanya diberikan cairan infus selama 24-48jam. Lalu diberikan ASI menggunakan pipa nasogastric.

2) Usia 30-32minggu : BBL 1.250gr-1500gr. Dapat menerika ASI dari sendok, 2 kali sehari namun masih dapat menerima makanan melalui pipa, namun lama-kelamaan makanan melalui pipa dapat dikurangi dan pemberian ASI dapat di tingkatkan.

3) Usia 32-34 minggu : BBL 1.500-1.800gr bayi mulai menyusui langsung dari payudara namun harus dengan penuh kesabaran. 
4) Usia >34 minggu : $\mathrm{BBL}>1.800 \mathrm{gr}$ mendapatkan semua kebutuhan dari payudara

k. Bayi kuning

Pencegahan ; segera menyusui setelah lahir dan jangan di batasi atau berikan ASI sesering mungkin. Berikan bayi kolostrum, kolostrum mengandung purgative ringan, yang dapat membantu bayi untuk mengeluarkan meconium . bilirubin dikeluarkan melalui feses, jadi kolostrum berfungsi mencegah dan menghilangkan bayi kuning.

I. Bayi kembar

Ibu optimis ASI-nya cukup, sesuai dengan football position, sesuai pada payudara dengan bergantian untuk variasi bayi, dan kemampuan menghisap bayi mungkin berbeda. Yakinkan pada ibu bahwa tuhan telah menyiapkan air susu untuk semua makhluk, sesuai dengan kebutuhan. Oleh karena itu semua ibu sebenarnya sanggup menyusui bayinya, wlaupun bayinya kembar.

m. Bayi sakit

Tidak ada alasan untuk menghentikan pemberian ASI. Untuk bayi dengan keadaan tertentu seperti diare, justru lebih banyak membutuhkan ASI untuk menghindari terjadina dehidrasi

n. Bayi sumbing

Bayi tidak akan mengalami kesulitan menyusu, cukup berikan posisi yang sesuai untuk bayi dengan sumbing pallatum molle (langit-langit lunak) dan pallatum durum ( langit-langit keras). Manfaat menyusui untuk bagi bayi sumbing : melatih kekuatan otot rahang dan lidah, memperbaiki perkembangan bicara, mengurangi resiko 
terjadinya otitis media. Untuk bayi dengan palatoskisis (celah pada langit-langit) : menyusui dengan posisi duduk, putting dan areola dipegang saat menyusui, untuk ibu jari ibu di gunakan sebagai penyumbat lubang . kalau mengalami labiopalatoskisis, berikan ASI dengan menggunakan sendok pipet dan dot panjang.

o. Bayi dengan lidah pendek (lingual frenulum)

Keadaan ini jarang terjadi, dimana bayi mempunyai jaringan ikat penghubung lidah dan dasar mulut yang tebal dan kaku sehingga membatasi gerak lidah, dan bayi tidak dapat menjulurkan lidah untuk menangkap dan mengikat putting dan areopa dengan benar

p. Bayi yang memerlukan perawatan

Ibu ikut dirawat supaya pemberian ASI bisa dilanjutkan. Seandainya tidak memungkinkan, ibu dianjurkan untuk memerah ASI setiap 3 jam dan disimpan di dalam lemari utuk kemudian sehari sekali dan diantar ke rumah sakit. Perlu ditandai pada botol waktu ASI tersebut ditampung, sehingga dapat diberikan sesuai jamnya. 